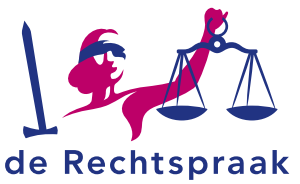

Research Memoranda

Nummer 2 / 2020

Jaargang 15

Raad voor de rechtspraak

\title{
Evaluatie pilot geïntegreerde aanpak huiselijk geweld
}

Nynke Piepers, Wendy Buysse en Mariëlle Bruning met medewerking van Bram van Dijk en Nina van Capelleveen 


\title{
Colofon
}

Raad voor de rechtspraak

Postbus 90613

2509 LP Den Haag

Deze publicatie verschijnt in het kader van het wetenschappelijk onderzoeksprogramma van de Raad voor de rechtspraak. Uitgave daarvan betekent niet dat de inhoud het standpunt van de Raad voor de rechtspraak weergeeft.

Onderzoek in opdracht van de Raad voor de rechtspraak.

\section{Begeleidingscommissie}

Mw. Prof. Dr. G.M.F..Römkes (voorzitter, voormalig hoogleraar gender based violance aan de UvA en oud-directeur van Atria (toen het onderzoek begon bekleedde ze beide functies))

Mr. J. van Schoonderwoerd den Bezemer-Wolters (landelijk officier van justitie Huiselijk geweld, kindermishandeling en zeden)

G. Walz (socioloog en onafhankelijk onderzoeker)

Mr. E. J. Stalenberg (jeugdrechter, coördinerend projectleider pilot integrale aanpak huiselijk geweld)

C.N.M. Zeebregts (procesregisseur Zorg- en Veiligheidshuis Rotterdam Rijnmond)
De integrale tekst van dit rapport is gratis te downloaden van: www.rechtspraak.nl/Organisatie/ Raad-Voor-De-Rechtspraak Rubriek: wetenschappelijk onderzoek

\author{
Uitgever \\ Xerox | OSAGE, Utrecht \\ Vormgeving \\ Corps, Den Haag \\ Opmaak binnenwerk \\ Xerox | OSAGE, Utrecht
}

De verantwoordelijkheid voor de inhoud berust bij de DSP Groep. Het gebruik van cijfers en/of teksten als toelichting of ondersteuning in artikelen, scripties en boeken is toegestaan mits de bron duidelijk wordt vermeld. Vermenigvuldigen en/of openbaarmaking in welke vorm ook, alsmede opslag in een retrieval system, is uitsluitend toegestaan na schriftelijke toestemming van de DSP Groep. DSP Groep aanvaardt geen aansprakelijkheid voor drukfouten en/of andere onvolkomenheden.

The responsibility for the contents of this report lies with DSP Group. Quoting numbers or text in papers, essays and books is permitted only when the source is clearly mentioned. No part of this publication may be copied and/or published in any form or by any means, or stored in a retrieval system, without the prior written permission of DSP Group. DSP Group does not accept responsibility for printing errors and/or other imperfections. 


\section{Evaluatie pilot geïntegreerde aanpak huiselijk geweld}

Nynke Piepers, Wendy Buysse en

Mariëlle Bruning met medewerking van Bram van Dijk en Nina van Capelleveen 


\section{Inhoudsopgave}

$\begin{array}{ll}\text { Voorwoord } & 6\end{array}$

$\begin{array}{ll}\text { Samenvatting } & 7\end{array}$

1 Inleiding: huiselijk geweld integraal behandelen 14

1.1 Aanleiding voor de pilot in Rotterdam 14

$\begin{array}{lll}1.2 & \text { Eerdere ervaring met integrale aanpak } & 16\end{array}$

$\begin{array}{lll}1.3 & \text { Doel van de pilot } & 17\end{array}$

1.4 Zaken die in aanmerking komen voor integrale behandeling 18

$\begin{array}{ll}1.5 & \text { Organisatie van de pilot } \\ 1.6 & 19\end{array}$

$\begin{array}{lll}1.6 & \text { Voormeting } & 20\end{array}$

$\begin{array}{lll}1.7 & \text { Leeswijzer } & 21\end{array}$

2 Onderzoeksaanpak 22

2.1 Onderzoeksvragen 22

2.2 Methodische verantwoording 22

3 Procesevaluatie 28

3.1 Voorbereiding van de pilot 28

3.2 Aanpassingen aan het reguliere werkproces 29

$\begin{array}{ll}\text { 3.3 Ervaring met en waardering van het werkproces } & 35\end{array}$

$\begin{array}{lll}3.4 & \text { Analyse tijdsbesteding } & 37\end{array}$

$4 \quad$ Effectevaluatie $\quad 43$

4.1 Samenwerking 44

4.2 Snelheid 48

$\begin{array}{lll}4.3 & \text { Integrale behandeling } & 48\end{array}$

$\begin{array}{lll}4.4 & \text { Kwaliteit van de interventies } & 60\end{array}$

4.5 Reflectie van de ketenpartners op de effecten 63

$\begin{array}{lll}4.6 & \text { Samenvatting effectevaluatie } & 65\end{array}$ 


\section{Conclusies en aanbevelingen}

5.1 Organisatorische en logistieke voorzieningen voor een geïntegreerde aanpak van huiselijk geweld

5.2 Effecten van de pilot

5.3 Reflectie van de onderzoekers op de resultaten

5.4 Lessen en aanbevelingen voor het vervolg

\section{Bijlagen}

Werkprocessen

Begeleidingscommissie 


\section{Voorwoord}

In dit rapport doen we verslag van een praktijkonderzoek naar de pilot geïntegreerde aanpak huiselijk geweld in Rotterdam. Huiselijk geweld is een ernstig maatschappelijk probleem dat ernstige gevolgen heeft voor alle betrokkenen. Wanneer er sprake is van huiselijk geweld speelt er vaak veel meer in het gezin. De rechtbank Rotterdam en het Zorg- en Veiligheidshuis Rotterdam Rijnmond en hun samenwerkingspartners hebben in een pilot enthousiast gewerkt aan een geïntegreerde aanpak van huiselijk geweld. Hiermee kan volgens ons een bijdrage worden geleverd aan het verminderen van de problematiek die huiselijk geweld veroorzaakt.

Het onderzoek en het rapport hadden niet tot stand kunnen komen zonder de medewerking en openheid van alle betrokken ketenpartners in de pilot. Het is eigen aan een pilot dat gedurende de looptijd op basis van ervaringen aanpassingen worden doorgevoerd. Als onderzoekers zijn we daar goed van de hoogte gehouden, zodat we het verloop van de pilot goed konden volgen.

Het onderzoek is in opdracht van de Stuurgroep' 'Geïntegreerde aanpak huiselijk geweld' uitgevoerd en begeleid door een begeleidingscommissie (zie bijlage 2). We willen de begeleidingscommissie bedanken voor hun kritische blik op het verloop van het onderzoek en hun constructieve en deskundige commentaar op meerdere versies van het conceptrapport. We hopen met dit onderzoek een bijdrage te leveren aan het verder doorontwikkelen van de integrale behandeling van huiselijk geweldzaken op de rechtbank.

Namens het projectteam, Wendy Buysse 


\section{Samenvatting}

Pieter sloeg Melanie op 4 januari met een glas, maar sloeg $M_{e l a n i e^{2}}$ nu met een kinderslipper of met een slof naar Pieter? Volgens de officier van justitie was het een slipper, volgens Melanies advocaat was het een slof. Kun je iemand trouwens mishandelen met een kinderslof? Een interessante vraag, maar daar zou het vanmiddag niet om moeten draaien in de Rotterdamse rechtszaal. 'Dit probleem is veel groter dan een slipper en een glas', vindt politierechter Yolanda Janssen. (Bron: www.rechtspraak.nl) ${ }^{3}$

In Nederland behandelt de politierechter lichte huiselijk geweldzaken. Als een verdachte van huiselijk geweld voor de politierechter verschijnt, is er meestal meer aan de hand in het gezin, zoals echtscheidingsproblematiek, kinderen die in hun ontwikkeling worden bedreigd of die veiligheidsrisico's lopen, schuldenproblematiek, psychische problematiek en/of verslavings- en agressieproblematiek. De verschillende soorten problematiek die in een gezin spelen kunnen tot verschillende rechtszaken leiden die apart worden behandeld door verschillende rechters. Tijdens de zitting van de politierechter gaat het alleen om de strafrechtelijke behandeling van de huiselijk geweldzaak. De rechter heeft meestal geen inzicht in eventuele andere lopende gerechtelijke procedures. Dit betekent voor het gezin in kwestie dat wanneer er sprake is van een strafzaak en eveneens van andere lopende procedures, deze niet in samenhang worden beoordeeld.

De rechtbank Rotterdam en het Zorg- en Veiligheidshuis Rotterdam-Rijnmond (ZVHRR) hebben de handen ineengeslagen om verandering aan te brengen in deze situatie. Als onderdeel van het streven van de Rechtspraak naar maatschappelijk effectieve rechtspraak, voeren zij sinds september 2018 een pilot 'Geïntegreerde aanpak huiselijk geweld' uit. Het doel van de pilot is het meer integraal behandelen van lichte huiselijk geweldzaken door strafzaken te combineren met civiele zaken in zogeheten combi-zaken op een huiselijk geweldzitting. 
Tussen september 2018 en maart 2020 zijn in de pilot 28 combi-zaken behandeld op een huiselijk geweldzitting. Dit is gemiddeld minder dan één combi-zaak per zitting.

Dit aantal is lager dan van tevoren verwacht. Op basis van een voormeting verwachtte de rechtbank en ZVHRR twee combi-zaken per week. Het bleek lastig om potentiële combi-zaken te detecteren en vervolgens te monitoren of er daadwerkelijk een civiele procedure tegelijkertijd met de strafzaak behandeld kan worden. Redenen daarvoor zijn dat procedures niet altijd gelijk lopen, verdachten en slachtoffers geen toestemming geven voor een integrale behandeling in een combi-zaak of dat er ondanks dat er sprake is van problematiek - toch geen civielrechtelijk verzoek wordt ingediend. De verwachting van twee combi-zaken per week bleek niet realistisch. De zittingscapaciteit die was gereserveerd voor combi-zaken is wel benut voor de behandeling van huiselijk geweldzaken en deze zaken zijn op die zitting ook anders behandeld dan op een reguliere politierechterzitting.

DSP-groep voerde samen met de Universiteit Leiden, in opdracht van de Stuurgroep geïntegreerde aanpak huiselijk geweld, tussen april 2019 en april 2020 een evaluatie uit van deze pilot. De evaluatie bestond uit een proces- en een effectevaluatie.

\section{Beoogde effecten van de pilot geïntegreerde aanpak huiselijk geweld}

Samen met de Raad voor de Kinderbescherming (RvdK), het Openbaar Ministerie $(\mathrm{OM})$, de Reclassering Nederland (RN), het Zorg- en Veiligheidshuis Zuid-Holland Zuid (ZVHZHZ) en Veilig Thuis (VT), willen de rechtbank en ZVHRR de samenwerking en informatie-uitwisseling verbeteren, en strafzaken sneller op zitting brengen en integraal - gecombineerd met civiele zaken - behandelen. De gedachte is dat daarmee de kwaliteit van de rechterlijke interventies wordt vergroot. Daarmee wordt bedoeld dat de interventies uit de verschillende juridische procedures beter op elkaar aansluiten, en op de problematiek en de behoeften in het gezin. De maatschappelijke impact die op de langere termijn met de pilot wordt beoogd, is het voorkomen van escalatie en herhaling van huiselijk geweld. Hoe de beoogde effecten met elkaar samenhangen, is weergegeven in het onderstaande figuur. 


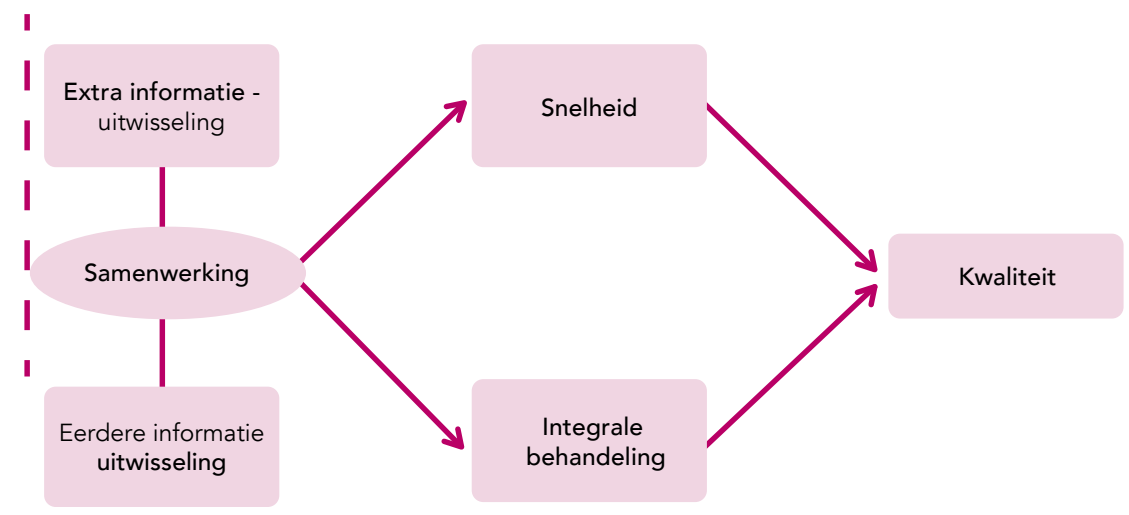

Organisatorische en logistieke voorzieningen voor een geïntegreerde aanpak In de procesevaluatie hebben we op basis van deskresearch en interviews met de rechtbank, het Veiligheidshuis en de ketenpartners de aanpassingen in het reguliere werkproces in kaart gebracht. Vervolgens zijn we nagegaan hoe hier in de praktijk uitvoering aan werd gegeven.

Het werkproces start op het moment dat een verdachte van huiselijk geweld wordt verhoord en eindigt op het moment dat hij of zij op zitting verschijnt. Om de doelen van de pilot te bereiken, is voorzien in aanpassingen in het werkproces zodat:

- zo vroeg mogelijk informatie beschikbaar is om te bepalen of een huiselijk geweldzaak in aanmerking komt voor de huiselijk geweldzitting en of het een potentiële combi-zaak is;

- deze potentiële combi-zaken binnen drie maanden op een speciale huiselijk geweldzitting worden gepland;

- deze potentiële combi-zaken worden gemonitord op gelijktijdig lopende civiele procedures;

- ketenpartners informatie aanleveren voor de integrale behandeling van de combi-zaken op een speciale huiselijk geweldzitting door een vaste poule van rechters en juridische ondersteuners. 
Om goed invulling te geven aan de geïntegreerde aanpak van huiselijk geweld, moeten de volgende zaken in het proces goed georganiseerd zijn:

- Alle ketenpartners (vanaf aanhouding van de verdachte door de politie tot de zitting) inclusief de advocaten, slachtoffers en SHN, moeten goed geïnformeerd zijn over de mogelijkheid van het combineren van de strafzaak met een civiele zaak (zowel familie- als jeugdrecht).

- Op verschillende momenten in het werkproces moet een toets worden uitgevoerd (ZSM/Veiligheidshuis en bij de rechtbank) op mogelijke civiele procedures die gecombineerd kunnen worden met de strafzaak.

- Om procedures meer gelijk te laten lopen en combi-zaken binnen drie maanden op de speciale huiselijk geweldzitting te kunnen behandelen, moeten afspraken omtrent het aanleveren van adviesrapportages die door de reclassering en de RvdK worden gemaakt, worden vastgelegd en moeten die afspraken ook worden nagekomen. Dit is nodig om zowel op ZSM als op de zitting eerder en meer informatie beschikbaar te hebben.

- Een vaste pool van rechters met kennis op meerdere rechtsgebieden die de zaken op de huiselijk geweldzitting behandelen.

- Vaste juridische ondersteuners met kennis van het strafrecht en de mogelijkheid om laagdrempelig collega's vanuit jeugd- en familierecht te raadplegen.

- Voldoende tijd voor de behandeling van zaken.

\section{Effecten van de pilot}

De effectevaluatie richtte zich op de kortetermijneffecten. De looptijd van de pilot is te kort om ook te kijken naar de effecten op langere termijn. De effecten zijn vooral kwalitatief in kaart gebracht.

\section{Samenwerking}

In de pilot is de samenwerking tussen het ZVHHR en de rechtbank vergroot. Door de pilot hebben zij meer inzicht in elkaars werkprocessen gekregen. Ook is de samenwerking tussen de rechtbank en het OM vergroot. Binnen het ZVHRR was er voorafgaand aan de pilot al een goede samenwerking tussen de ketenpartners. Door de pilot is de samenwerking met betrekking tot huiselijk geweld tussen deze ketenpartners nog verder verbeterd.

Het is in de pilot grotendeels gelukt om eerder informatie beschikbaar te hebben, om zo potentiële combi-zaken eerder op het spoor te komen en ook om relevante informatie eerder beschikbaar te hebben voor de behandeling van de huiselijk geweldzaken op zitting. Zo is er meer informatie beschikbaar in de processen-verbaal over de gezinssituatie en eventuele echtscheidings- of gezinsproblematiek. Dit maakt identificatie van potentiële combizaken bij de ZSM-aanpak beter mogelijk. Ook voor de behandeling van de zaak op de huiselijk geweldzitting is meer informatie beschikbaar. Zo is er altijd een adviesrapportage van de reclassering beschikbaar, 
welke normaliter voor de politierechterzitting alleen wordt opgevraagd indien de officier van justitie dat nodig vindt. Een aandachtspunt - hoewel dit in de loop van de pilot verbeterd is - is het ontbreken van informatie van VT in sommige adviesrapportages van RN. Verder lukt het RN niet in alle gevallen om adviesrapportages binnen de afgesproken verkorte termijn van acht weken aan te leveren. Dit is evenwel geen belemmering zo lang de rapportages beschikbaar zijn voorafgaand aan de huiselijk geweldzitting, wat feitelijk altijd het geval is. Voor de rapportages van de RvdK geldt dat het vanwege wachtlijsten niet altijd lukt om de rapportage tijdig aan te leveren, maar er zijn afspraken gemaakt om dit knelpunt te verbeteren.

Er is niet alleen meer informatie beschikbaar voor de zitting, ook de rechter gaat tijdens de zitting zelf op zoek naar meer informatie. Zo stelt hij bijvoorbeeld, meer dan in een reguliere politierechterzitting, vragen aan de verdachte en het slachtoffer over eventueel spelende achterliggende problematiek.

\section{Snelheid}

Tijdens de pilot zijn alle zaken die worden aangemeld voor de huiselijk geweldzitting binnen drie maanden op zitting gepland. Dit is sneller dan bij reguliere politierechterzittingen. We maken hierbij wel de kanttekening dat sneller op zitting komen niet hoeft te betekenen dat er sneller uitspraak wordt gedaan. Rechters vermoeden dat zij in de pilot huiselijk geweldzaken vaker aanhouden. In de periode tot de volgende zitting wordt dan gestart met bijvoorbeeld mediation of hulpverlening. Rechters houden zaken aan om een vinger aan de pols te houden - deze verlenging van doorlooptijden hoeft dus niet negatief geduid te worden.

\section{Integrale behandeling}

Zoals eerder gezegd, is het aantal combi-zaken dat op een huiselijk geweldzitting is behandeld lager dan verwacht. Op basis van de aantallen is het doel van de pilot niet gehaald. Tijdens de pilot werd echter steeds duidelijker dat integrale behandeling van huiselijk geweldzaken meer is dan alleen het combineren van verschillende juridische procedures. De pilot heeft in kwalitatieve zin inzicht gegeven in wat bij een integrale behandeling van huiselijk geweld komt kijken. Rechters behandelen de huiselijk geweldzaken vanuit het besef dat er bij huiselijk geweld - ook als er geen civiele zaak wordt behandeld - vaak meer aan de hand is dan het incident waarvoor de verdachte terechtstaat. Met dat in gedachten zijn rechters tijdens de pilotzittingen erop gericht niet alleen informatie te verzamelen die ze nodig hebben voor het afdoen van de strafzaak. Ze zijn ook gericht op het verzamelen van informatie die ze nodig hebben om met de juridische interventies bij te dragen aan een oplossing voor het verminderen van de onderliggende problematiek. Ook als er alleen een strafzaak op een huiselijk geweldzitting gepland staat, kan met een meer integrale blik op efficiëntere wijze naar oplossingen voor het conflict of de problematiek worden 
gekeken. En dat doen de rechters in de pilot ook. Voor de aanpak van huiselijk geweld is specifieke deskundigheid nodig - niet alleen bij rechters - maar bij alle betrokken ketenpartners.

\section{Kwaliteit van rechterlijke interventies}

De resultaten van het onderzoek maken aannemelijk dat de kwaliteit van rechterlijke interventies is vergroot. De rechters stemmen de rechtelijke interventies op elkaar af, op interventies in het vrijwillig kader en op de achterliggende problematiek.

Verdachten en slachtoffers voelen zich meer gehoord. De rechterlijke interventies zijn naast straffen, gericht op het herstellen van de veiligheid in het gezin en op hulpverlening. Bij politierechterzittingen en civiele zaken (zonder strafzaak) kan het voorkomen dat de rechter een uitspraak doet die bijt met eerdere uitspraken die zijn gedaan, al dan niet in het andere rechtsgebied. Dat gezegd hebbende, in dit onderzoek is niet nagegaan welke interventies zijn ingezet en er was geen vergelijking mogelijk tussen interventies in pilotzaken en interventies in zaken die volgens de reguliere wijze worden behandeld. De randvoorwaarde voor kwalitatief hoogwaardige rechterlijke interventies, is dat rechters kennis hebben van de verschillende rechtsgebieden en van de sociale kaart.

\section{Lessen en aanbevelingen voor het vervolg}

Hoewel we op basis van de pilot niet kunnen concluderen wat het effect is van een integrale behandeling op de gezinnen, zijn we van mening dat de pilot goede aanknopingspunten biedt voor de toekomstige aanpak van huiselijk geweldzaken. Het is nu het moment om de aanpak door te ontwikkelen. Door de focus te leggen op de problematiek achter het huiselijk geweld en daardoor de schade te beperken, kan worden bijgedragen aan het stoppen en terugdringen van het huiselijk geweld. Het combineren van juridische procedures is daarbij mooi meegenomen, maar moet niet het doel zijn. De verdieping van de aanpak moet vooral worden gezocht in het integraal in kaart brengen van de problematiek achter het huiselijk geweld.

Het is daarbij aan te raden om de rechter eerder in het proces een regierol toe te bedelen. Hiermee ontwikkelt de aanpak zich richting de huiselijk geweldzitting (domestic violence courts) in andere landen.

De aandachtspunten uit de pilot zijn ook breder waardevol voor een geïntegreerde aanpak van rechterlijke procedures:

- Het creëren van draagvlak bij alle ketenpartners en herhaalde voorlichting is een belangrijke randvoorwaarde.

- Privacyregels omtrent het delen van informatie tussen het civiele en strafrechtelijke domein moeten verder worden uitgezocht. 
- De plaats van de verdachte en het slachtoffer naast elkaar in de zittingsruimte van de rechtbank bevordert de dialoog en kan worden gezien als een best practice. In het vervolg moet verder worden uitgezocht wat de ervaringen van slachtoffers zijn en wat de verschillende juridische grondslagen van de zaken betekenen voor de plaatsing in de zittingsruimte.

Tot slot, het enthousiasme en de goede samenwerking in deze pilot laten het draagvlak voor een meer integrale aanpak van huiselijk geweld zien, en - ondanks de barrières die moeten worden overwonnen - het belang ervan. Dit zijn goede redenen voor de doorontwikkeling van de aanpak. 


\section{Inleiding: huiselijk geweld integraal behandelen}

\subsection{Aanleiding voor de pilot in Rotterdam}

Pieter sloeg Melanie op 4 januari met een glas, maar sloeg Melanie ${ }^{4}$ nu met een kinderslipper of met een slof naar Pieter? Volgens de officier van justitie was het een slipper, volgens Melanies advocaat was het een slof. Kun je iemand trouwens mishandelen met een kinderslof? Een interessante vraag, maar daar zou het vanmiddag niet om moeten draaien in de Rotterdamse rechtszaal. 'Dit probleem is veel groter dan een slipper en een glas', vindt politierechter Yolanda Janssen. (Bron: www.rechtspraak.nl) ${ }^{5}$

Politierechters behandelen huiselijk geweldstrafzaken waarvoor maximaal een gevangenisstraf van één jaar kan worden opgelegd, ${ }^{6}$ en waarin zij, mits de strafzaak niet wordt aangehouden, diezelfde dag uitspraak doen. ${ }^{7}$ Waar huiselijk geweld speelt, is echter meestal meer aan de hand, zoals echtscheidingsproblematiek, kinderen die in hun ontwikkeling worden bedreigd of veiligheidsrisico's lopen, schuldenproblematiek, psychische problematiek, verslavings- en agressieproblematiek. De verschillende soorten problematiek die in een gezin spelen, kunnen tot verschillende rechtszaken leiden die apart behandeld worden door verschillende rechters.

Tijdens de zitting van de politierechter gaat het alleen om de strafrechtelijke behandeling van de huiselijk geweldzaak. De rechter heeft meestal geen inzicht in eventueel andere lopende gerechtelijke procedures. Dit betekent voor het gezin in kwestie dat wanneer er sprake is van een strafzaak en andere lopende procedures, deze niet in samenhang worden beoordeeld.

Volgens het projectplan Geïntegreerde aanpak huiselijk geweld Rotterdam (hierna: projectplan) worden in Rotterdam in het Zorg en Veiligheidshuis Rotterdam Rijnmond (ZVHRR) jaarlijks op ZSM ca. 1.000 gevallen besproken waarbij sprake is van

$4 \quad$ Dit zijn niet hun echte namen.

5 https://www.rechtspraak.nl/Organisatie-en-contact/Organisatie/Rechtbanken/RechtbankRotterdam/Nieuws/Paginas/Op-de-rol-Niemand-schiet-op-met-een-harde-straf.aspx. 
(verdenking van) huiselijk geweld. ${ }^{8,9}$ Bij de rechtbank Rotterdam worden jaarlijks ongeveer 300 huiselijk geweldzaken behandeld, waarbij ook sprake is van andere problematiek in het gezin en waarbij op systeemniveau (het niveau van het gezin) meerdere juridische procedures lopen, zoals echtscheidingsprocedures, ondertoezichtstellingen en leerplichtzaken. ${ }^{10}$

Bij het ZVHRR is er een casusoverleg huiselijk geweld met de veiligheidspartners (politie, Openbaar Ministerie, Raad voor de Kinderbescherming, Veilig Thuis, Jeugdbescherming, Slachtofferhulp Nederland, Dienst Justitiële Inrichtingen (DJI), de Reclassering en gemeente). Dit overleg is ingestoken op gezinsniveau en bedoeld om met de veiligheidspartners tot een gezamenlijk plan van aanpak te komen voor het huiselijk geweld. In het projectplan schetsen het ZVHRR en de rechtbank het probleem dat de samengebrachte informatie na het casusoverleg weer versnippert, omdat de verschillende partners elk hun weg gaan. Verder is geconstateerd dat die strafzaken vaak onvoldoende snel ter zitting komen. Dit belemmert een effectieve rechterlijke aanpak van het huiselijk geweld.

De rechtbank Rotterdam en het ZVHRR, hebben de handen ineengeslagen om een betere, geïntegreerde aanpak te ontwikkelen voor rechtszaken die gerelateerd zijn aan huiselijk geweld. Als onderdeel van het streven van de Rechtspraak naar Maatschappelijk effectieve rechtspraak, voeren zij sinds september 2018 een pilot 'Geïntegreerde aanpak huiselijk geweld' uit. Het doel van de pilot is een werkwijze te ontwikkelen voor het meer integraal behandelen van huiselijk geweldzaken door strafzaken te combineren met civiele zaken in zogeheten combi-zaken op een huiselijk geweldzitting. Het gaat hierbij om lichte huiselijk geweldzaken en niet om de huiselijk geweldzaken die door een meervoudige kamer behandeld moeten worden. Onder huiselijk geweld wordt verstaan geweld dat wordt gepleegd door iemand uit de huiselijke of familiekring van het slachtoffer.

Met de geïntegreerde aanpak huiselijk geweld willen de rechtbank Rotterdam en het ZVHRR een bijdrage leveren aan het aanpakken van huiselijk geweld. Zoals in het projectplan verwoord: Huiselijk geweld is een ernstig maatschappelijk probleem: het is ingrijpend voor de betrokkenen en kan ernstige gevolgen hebben voor de gezondheid en het welzijn van de slachtoffers, waartoe vaak (ook) kinderen behoren.

$8 \quad$ Projectplan Geïntegreerde aanpak huiselijk geweld Rotterdam (1 september 2017). Raad voor de Rechtspraak, rechtbank Rotterdam en Veiligheidshuis Rotterdam-Rijnmond.

9 De ZSM-aanpak is voor de strafrechtelijke behandeling van veelvoorkomende criminaliteit, zoals diefstal, vernieling, licht uitgaansgeweld en verduistering. Op ZSM-locaties zitten alle ketenpartners bijeen om in elke zaak maatwerk te kunnen leveren, en bovendien zo snel mogelijk tot een afdoeningsbeslissing te komen. Via: https://www.strafrechtketen.nl/onderwerpen/zsm.

10 Projectplan Geïntegreerde aanpak huiselijk geweld Rotterdam (1 september 2017). Raad voor de Rechtspraak, rechtbank Rotterdam en Veiligheidshuis Rotterdam-Rijnmond. 
Een goede en snelle aanpak is belangrijk vanwege het gewelddadige karakter van huiselijk geweld, de gevolgen daarvan in het latere leven van slachtoffers en hun naaste omgeving en ook vanwege de maatschappelijke kosten die ermee gemoeid zijn (zoals bijvoorbeeld die voor de inzet van justitiële organisaties en instanties voor geestelijke en maatschappelijke hulpverlening). ${ }^{11}$

DSP-groep voerde samen met de Universiteit Leiden, in opdracht van de Stuurgroep geïntegreerde aanpak huiselijk geweld, tussen april 2019 en april 2020 een evaluatie uit van deze pilot. De evaluatie bestond uit een proces- en een effectevaluatie. In deze rapportage wordt verslag gedaan van het evaluatieonderzoek.

Alvorens in te gaan op de aanpak van het evaluatieonderzoek en de resultaten, beschrijven we eerdere ervaring met integrale aanpak en geven een beschrijving van de pilot (doel, zaken die in aanmerking komen voor de pilot, de organisatie van de pilot en een voormeting die door de rechtbank en ZVHRR is uitgevoerd).

\subsection{Eerdere ervaring met integrale aanpak}

Het Rotterdamse initiatief is niet het eerste initiatief waarin zaken uit verschillende rechtsgebieden worden gecombineerd. In onderzoek uit 2006 kwam de behoefte van jeugdrechters om civiele- en strafrechtelijke aspecten van jeugdzaken goed op elkaar af te stemmen al aan bod. ${ }^{12}$ Afstemming van rechtsgebieden vereist volgens jeugdrechters kennis van beide rechtsgebieden bij rechters. Destijds werd al voorgesteld om teams samen te stellen van rechters die zowel civiel- als strafrecht doen. Naast kennis van beide rechtsgebieden, is informatie-uitwisseling een aandachtspunt. Destijds kwam naar voren dat er te weinig informatie-uitwisseling was tussen rechtsgebieden. Echter, ook binnen een rechtsgebied waren jeugdrechters niet altijd om de hoogte van relevante beslissingen die in het verleden zijn genomen. En ook tussen ketenpartners binnen de jeugdbeschermingsketen bleek er weinig van 'systeemperspectief' en waren ketenpartners vooral gericht om het behalen van hun eigen doelstellingen.

Bij verschillende rechtbanken (onder welke Den Haag, Amsterdam, Arnhem, Assen, Breda, Rotterdam, Utrecht en Zutphen) is ervaring opgedaan met combi-zittingen waarbij jeugdrecht werd gecombineerd met jeugdstrafrecht. In 2009 is onderzoek gedaan naar een pilot met combi-zittingen voor jeugdigen bij de rechtbank Arnhem (nu rechtbank Gelderland). ${ }^{13}$ Bij de combi-zitting gaat het om een samenloop van jeugdstrafzaken, leerplichtzaken en/of civiele jeugdbeschermingszaken. Uit de evaluatie van die pilot bleek dat rechters die bij de pilot betrokken waren naar eigen zeggen een breed beeld van het kind kregen, omdat de rechter informatie had over de verschillende zaken die de jeugdige betroffen. Doordat rechters van de

11 Projectplan Geïntegreerde aanpak huiselijk geweld Rotterdam (1 september 2017). Raad voor de Rechtspraak, rechtbank Rotterdam en Veiligheidshuis Rotterdam-Rijnmond.

12 Verberk, H. G. E., \& Fuhler, K. (2006). De positionering van de jeugdrechter. Raad voor de rechtspraak.

13 Baas, R. \& Laemers, M. (2009). 'Combi-zitting': meer recht doen aan jeugdigen. Den Haag: Raad voor de Rechtspraak. 
verschillende problemen en casus op de hoogte waren, konden zij beslissingen in de verschillende zaken op elkaar afstemmen. Ook bleek uit de evaluatie dat een combi-zaak praktische voordelen heeft; kinderen en ouders hoefden immers maar één keer op zitting te verschijnen.

Ander onderzoek uit 2014 plaatst een aantal randvoorwaarden en kanttekeningen bij een gecombineerde aanpak. ${ }^{14}$ Zo is het van belang dat de proceswaarborgen, bijvoorbeeld met betrekking tot spreekrecht, die binnen de verschillende juridische domeinen gelden, niet in het geding komen. Een duidelijke behandelstructuur en de aanwezigheid van een advocaat of advocaten kunnen hierbij helpen. Tevens kwam in laatstgenoemd onderzoek naar voren dat er een grotere kans bestaat dat de jeugdige veroordeeld wordt doordat ook problemen in het civiele kader bij de rechter bekend zijn, wat door een negatieve indruk van de jeugdige kan leiden tot het eerder opleggen van een straf dan bij een reguliere behandeling. Tot slot bleek uit dat onderzoek dat het samenbrengen van combi-zaken lastig en een tijdrovende opgave is.

\subsection{Doel van de pilot}

In de pilot zijn bij de opzet diverse doelstellingen geformuleerd. Om deze doelstellingen te kunnen onderzoeken, of, met andere woorden, om te zien of de pilot werkt zoals die is bedoeld, hebben we deze geëxpliciteerd en geoperationaliseerd.

\section{Impact op langere termijn}

De pilot beoogt om op lange termijn maatschappelijke impact te hebben door het voorkomen van escalatie en herhaling van huiselijk geweld. De looptijd van de pilot is te kort om ook te kijken naar de effecten op langere termijn. Deze vallen dus ook buiten het bereik van dit onderzoek. Het onderzoek richt zich op de directe korte termijneffecten.

\section{Beoogde effecten van de pilot (output en outcome)}

Met de pilot worden vier doelen beoogd. Drie hebben betrekking op de output:

1. Samenwerking: meer samenwerking tussen de ketenpartners in de vorm van extra en eerdere informatie-uitwisseling. Dit zijn voorwaarden voor een snellere en integrale behandeling van huiselijk geweldzaken.

2. Snelheid: een snellere behandeling van huiselijk geweldzaken, dat wil zeggen; het sneller op zitting brengen van de strafzaken.

3. Integraliteit: het integraal (gezamenlijk) behandelen van strafrechtelijke en andere lopende juridische procedures - uit familie- en jeugdrecht - (zogenaamde combi-zaken) in het gezin op één huiselijk geweldzitting. 
En op het niveau van outcome:

4. Kwaliteit: juridische interventies uit de verschillende zaken in een gezin zijn op elkaar afgestemd en sluiten aan op de problematiek van het gezin. Door het integraal en sneller behandelen van de huiselijk geweldzaken wordt de kwaliteit van rechterlijke interventies die worden ingezet, verhoogd.

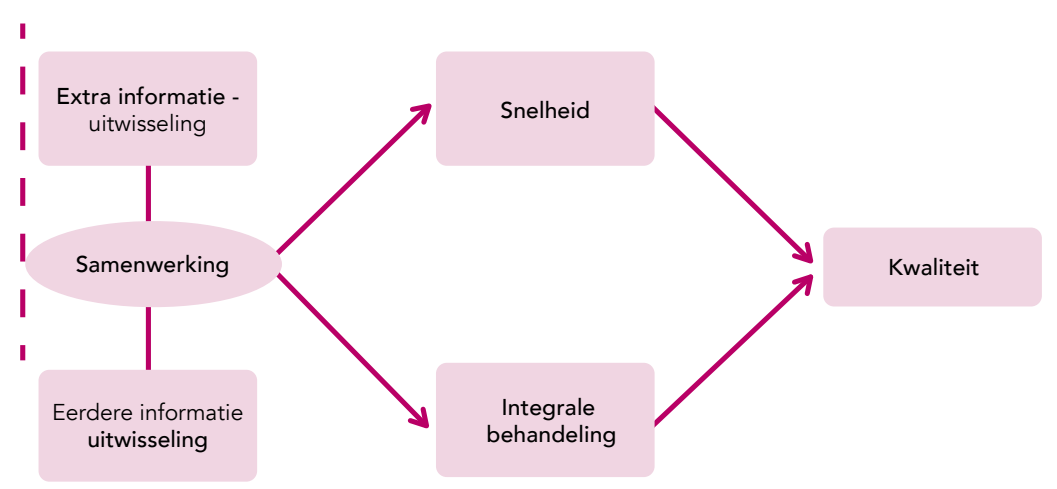

Figuur 1.1 Beoogde effecten van de pilot geïntegreerde aanpak huiselijk geweld.

\subsection{Zaken die in aanmerking komen voor integrale behandeling}

Zoals in de aanleiding beschreven, richt de pilot zich op huiselijk geweldzaken die door de politierechter worden behandeld. De pilot richt zich primair op het combineren van huiselijk geweldzaken met zaken in het familie- en jeugdrecht. In de pilot noemen ze de gecombineerde zaken 'combi-zaken'. Bij familierecht gaat het om zaken die betrekking hebben op bijvoorbeeld een echtscheiding, omgangsregelingen of het gezag over de kinderen. Bij jeugdrecht gaat het om

jeugdbeschermingsmaatregelen, zoals ondertoezichtstelling en uithuisplaatsingen. In dit rapport spreken wij over civiele zaken als gerefereerd wordt naar het familie- en/of jeugdrecht. Gezien de ernst van zaken die doorgaans door een meervoudige kamer worden behandeld, is het niet opportuun om deze te combineren met andere gerechtelijke procedures. Deze zaken vallen dan ook buiten de pilot. De strafzaken die wel in aanmerking komen voor de huiselijk geweldzitting in de pilot betreffen dus relatief 'lichtere' huiselijk geweldzaken.

\section{Voorbeeld van een casus voor een combi-zaak}

Simon en Suzanne zijn al 2,5 jaar uit elkaar. Ze hebben samen twee jonge kinderen. 
Simon en Suzanne hebben afgesproken dat Simon de kinderen woensdagmiddag ziet en om de week in het weekend. Over de omgang hebben de twee echter regelmatig conflicten, omdat Simon niet altijd op tijd komt op zijn afspraken en volgens Suzanne blowt waar de kinderen bij zijn. Suzanne houdt volgens Simon op haar beurt de kinderen bij Simon weg door te zeggen dat de kinderen ziek zijn of geen zin hebben om met hun vader mee te gaan. Simon heeft een advocaat in de arm genomen om nieuwe afspraken over de omgang te maken. Hij wil co-ouderschap en anders wil hij de kinderen elke woensdag na school tot donderdagochtend zien, en om de week in het weekend.

Op een dag komt Simon de kinderen op vrijdag in plaats van vóór het eten na het eten ophalen. Volgens Suzanne heeft hij gedronken en geblowd met zijn collega's. Simon zegt daarentegen dat hij in de file stond. Suzanne wil niet dat de kinderen die avond nog met hun vader meegaan. Er ontstaat een woordenwisseling en Simon geeft Suzanne een klap. Ze komt daarbij ongelukkig ten val, maar heeft gelukkig haar neus niet gebroken, zo blijkt later in het ziekenhuis.

De kinderen hebben de confrontatie gezien en zijn erg overstuur. De buren hebben gezien dat Simon Suzanne een klap gaf en hebben daarop de politie gebeld. Simon wordt op het politiebureau verhoord. Simon is erg verdrietig over wat er is gebeurd en heeft spijt dat zijn kinderen de confrontatie hebben gezien. Sinds het incident (3 maanden geleden) heeft Simon de kinderen niet meer gezien.

De advocaten van Simon en Suzanne hebben allebei ingestemd met een gecombineerde behandeling van de strafzaak en de omgangsregeling.

\subsection{Organisatie van de pilot}

De pilot is opgezet door de projectorganisatie, bestaande uit de stuurgroep, de coördinerend projectleider en de operationele werkgroep van het ZVHRR en de rechtbank. In de pilot werken de rechtbank Rotterdam en het ZVHRR samen met de Openbaar Ministerie (OM), Zorg- en Veiligheidshuis Zuid-Holland Zuid (ZVHZHZ), ${ }^{15}$ Advies- en Triagepunt (APT), Reclassering Nederland (RN), Raad voor de Kinderbescherming (RvdK), Veilig Thuis (VT) en de politie.

De projectorganisatie heeft met veel enthousiasme het werkproces opgesteld en ingericht (zie hoofdstuk 3), en is aan de slag gegaan met het infomeren en communiceren binnen de eigen organisatie, naar de samenwerkingspartners en advocatuur over de pilot en heeft de voormeting uitgevoerd (zie 1.6).

15 Gedurende de pilot is ZVHZHZ bij de pilot betrokken geraakt. In dit rapport wordt gesproken van 'het Veiligheidshuis' als gerefereerd wordt naar het VHZHZ en ZVHRR wordt bedoeld. Indien enkel wordt verwezen naar ZVHRR gaat het om afspraken die zijn gemaakt voordat VHZHZ bij de pilot was betrokken of ervaringen met de pilot die expliciet door de respondenten van ZVHRR zijn benoemd. 


\section{$1.6 \quad$ Voormeting}

De rechtbank Rotterdam en het ZVHRR hebben in de voorbereidingsfase van de pilot een voormeting ${ }^{16}$ uitgevoerd om inzicht te krijgen in de doorlooptijden van huiselijk geweldzaken die door een politierechter zijn behandeld, en hoeveel huiselijk geweld zaken in theorie gecombineerd kunnen worden met een civiele zaak. Er is door de rechtbank een steekproef van 62 zaken getrokken die in 2015 en 2016 door de politierechter zijn behandeld én waarbij de achternaam van de verdachte met de letter A begon. Daarna is gekeken of naast de strafzaak sprake was van een civiele zaak en is onderzocht of de zaak aanhangig is gemaakt in de periode tussen de pleegdatum en zittingsdatum bij de politierechter. De rechtbank heeft hierbij gekeken naar: datum aangifte strafbaar feit, relatie aangever-persoon, aanhouding en verzekeringstelling, reclasseringsadvies, zittingsdatum politierechter en bijzondere voorwaarden. Met betrekking tot de civiele zaak hebben ze gekeken naar soort civiele zaak, datum indienen verzoekschrift, verzoeker, zittingsdatum en eindafspraak. ${ }^{17}$

\section{Rechtbank Rotterdam}

Veertien van de 62 zaken (23\%) bleken met de civiele zaak gecombineerd te kunnen worden, gelet op de termijnen (dat wil zeggen als de civiele zaak aanhangig is gemaakt tussen de pleegdatum van het huiselijk geweld en de zittingsdatum (uitspraakdatum) bij de politierechter). Vijf van deze veertien zaken ( $8 \%$ van de totale steekproef) bleken ook op inhoud te combineren. 'Op inhoud combineren' houdt in dat de civiele zaak aan het huiselijk geweld gerelateerd is. ${ }^{18}$ Vier van de veertien (6,5\% van de totale steekproef) strafzaken bleken te combineren na afstemming over bijvoorbeeld de termijn waarop de civiele zaak en de strafzaak behandeld worden. De overige vijf huiselijk geweldzaken bleken bij nader inzien niet te combineren.

De percentages uit de steekproef zijn toegepast op het totaal aantal huiselijk geweldzaken in 2015 en 2016 om een inschatting te maken van het jaarlijks totaal aantal te combineren huiselijk geweldzaken met civiele zaken. In 2015 zijn er circa 1070 huiselijk geweldzaken door een politierechter behandeld en in 2016 circa 1008. Het gaat in totaal om 2078 huiselijk geweldzaken. Het gaat zodoende om circa 300 huiselijk geweldzaken of 15\% van de zaken die in 2015 en 2016 te combineren waren. Dit komt neer op circa 150 huiselijk geweld combi-zaken per jaar. Uitgaande van een 52 weken per jaar, levert dit 2,9 te verwachten combi-zaken per week op. Als rekening wordt gehouden met perioden van reces, achtte de rechtbank op basis van de voormeting circa twee combi-zaken per week reëel.

Bij de veertien huiselijk geweldzaken die gezien de termijn te combineren waren, is eveneens gekeken naar de doorlooptijd tussen de datum van aangifte en de datum van de uitspraak. Bij die huiselijk geweldzaken varieerde de doorlooptijd tussen de 2 en 20 maanden, met een gemiddelde van circa 9 maanden.

16 De rechtbank en ZVHRR spreekt van een dossieronderzoek in plaats van een voormeting.

17 Wij hebben geen zicht in deze kenmerken.

18 Een voorbeeld van civiele zaak die niet op inhoud te combineren is met een huiselijk geweldzaak is een faillissement. 


\section{ZVHRR}

Vervolgens heeft het ZVHRR in de steekproef van 62 huiselijk geweldzaken onderzocht welke informatie in de applicatie voor de PersoonsGerichteAanpak (vPGA) beschikbaar was. En op basis daarvan is bepaald of bij instroom op ZSM, op basis van de informatie in VPGA, beoordeeld kon worden of een zaak in aanmerking komt voor een combi-zaak (voor het werkproces na aanhouding van een verdachte van een huiselijk geweldzaak verwijzen we naar bijlage 1). Het ZVHRR heeft specifiek gekeken wat er van de verdachte bekend is in VPGA, of er een ZSM-melding omstreeks de pleegdatum is gemaakt en welke informatie geregistreerd is over andere (civiele) trajecten.

Van de 62 dossiers uit de steekproef van de rechtbank waren er bij het ZVHRR 49 dossiers bekend. Voor deze 49 strafzaken is er omstreeks de pleegdatum een ZSM-melding gedaan. Dertien strafzaken waren niet bij het ZVHRR bekend. In zeven strafzaken bleek uit de informatie in vPGA dat parallel aan de strafzaak een civiel traject of trajecten liep(en). Dit komt ook neer op 15\% van de zaken.

Van de 49 strafzaken was $11 \%$ op inhoud te combineren. Uit de informatie uit vPGA bleek dat in een aantal ${ }^{19}$ van de dossiers informatie stond die aanleiding gaf tot navraag bij de RvdK. Uit de navraag bij de RvdK bleek dat er in een aantal zaken wel sprake was van een civiele zaak, ondanks dat die informatie niet in VPGA was opgenomen. Op basis van de informatie in vPGA is het dus niet altijd mogelijk om te bepalen of er mogelijk sprake is van een combi-zaak. Over het algemeen bleek verder uit de voormeting bij ZVHRR dat de civiele informatie in VPGA zeer beperkt is. Het is niet duidelijk aangegeven wanneer er bijvoorbeeld sprake is van een (voorlopige) ondertoezichtstelling, uithuisplaatsing of huisverbod. Op basis van deze bevindingen in de voormeting heeft het ZVHRR de registratie van deze gegevens in het werkproces van de pilot aangepast.

\subsection{Leeswijzer}

In het vervolg van het rapport doen we verslag van de proces- en effectevaluatie. In hoofdstuk 2 beschrijven we de onderzoeksaanpak. In hoofdstuk 3 beschrijven we de resultaten van de procesevaluatie. We beschrijven de organisatorische en logistieke aanpassingen in het reguliere werkproces van strafrechtelijke behandeling van huiselijk geweldzaken en vergelijken de werkwijze in de pilot met het werkproces van een reguliere strafrechtelijke behandeling van huiselijk geweldzaken. Ook gaan we in op de ervaringen met werkproces en de tijdsbesteding. De resultaten van de effectmeting op de doelen (output en outcome) presenteren we in hoofdstuk 4. In hoofdstuk 5 trekken we conclusies, reflecteren we op de uitkomsten van het onderzoek en doen we aanbevelingen voor het vervolg. 


\section{Onderzoeksaanpak}

\subsection{Onderzoeksvragen}

De evaluatie van de pilot moet antwoord geven op drie onderzoeksvragen:

5. Welke organisatorische en logistieke voorzieningen (inclusief ureninzet) zijn getroffen door het ZVHRR en de rechtbank om de integrale behandeling van huiselijk geweldzaken mogelijk te maken? En hoe is hier in de praktijk invulling aan gegeven?

6. In hoeverre slaagt de pilot erin om de effecten te realiseren die met de pilot zijn beoogd?

7. Wat leert deze pilot over voor succes noodzakelijke of voldoende elementen bij de inrichting ervan?

\subsection{Methodische verantwoording}

Het onderzoek bestaat uit een procesevaluatie en een effectevaluatie op de output en outcome variabelen (zie 1.3).

De procesevaluatie geeft antwoord op de onderzoeksvraag over welke organisatorische en logistieke voorzieningen zijn getrokken door het ZVHRR en de rechtbank om de integrale behandeling van huiselijk geweld mogelijk te maken en hoe hier in de praktijk invulling is aan gegeven.

De effectevaluatie geeft antwoord op de vraag in welke mate de doelen van de pilot zijn bereikt. Hiervoor zijn de volgende indicatoren gebruikt:

- Samenwerking: ervaringen van de ketenpartners over extra en eerdere informatie-uitwisseling

- Snelheid: de doorlooptijd van de huiselijk geweld strafzaken tussen pleegdatum en uitspraak rechtbank

- Integrale behandeling: aantal combi-zaken en ervaringen van rechters, Openbaar Ministerie, advocaten en andere ketenpartners met de integrale behandeling 
- Kwaliteit: ervaring van rechters met de rechterlijke interventies die na behandeling op de huiselijk geweldzitting zijn ingezet

Op basis van de uitkomsten van de proces- en effectevaluatie beantwoorden we de derde onderzoeksvraag.

In de procesevaluatie en de effectevaluatie zijn verschillende onderzoeksmethoden ingezet, zoals in het volgende schema duidelijk wordt. Sommige methoden zijn zowel ingezet voor de procesevaluatie als voor de effectevaluatie. Op basis van de uitkomsten van de proces- en effectevaluatie is de tweede onderzoeksvraag beantwoord.

\begin{tabular}{ll}
\hline Procesevaluatie & Effectevaluatie \\
\hline Documentanalyse & Enquête onder betrokkenen advocaten \\
$\begin{array}{l}\text { Interviews met projectleiders en } \\
\text { (direct) bij uitvoering betrokken } \\
\text { ketenpartners }\end{array}$ & $\begin{array}{l}\text { Interviews met projectleiders en (direct) } \\
\text { bij uitvoering betrokken ketenpartners }\end{array}$ \\
$\begin{array}{l}\text { Reflectiebijeenkomst } \\
\begin{array}{l}\text { Analysetijdsbesteding opzet en } \\
\text { uitvoering pilot } \\
\text { Observaties van combi-zittingen }\end{array}\end{array}$ & Reflectiebijeenkomsten \\
\hline
\end{tabular}

\section{Documentenanalyse}

We analyseerden het projectplan, de werkprocessen en aanvullende beschikbare documentatie van de rechtbank en ZVHRR over de pilot om inzicht te krijgen in het doel van de pilot, het werkproces en de inzet van de projectorganisatie in de ontwikkelperiode. Daarnaast analyseerde we het dynamische voortgangsdocument dat gedurende de looptijd van de pilot door de projectorganisatie is bijgehouden. In dit document staan de afspraken en stappen die door de projectorganisatie gedurende de pilot zijn gemaakt. Op basis van de documentenanalyse maakten we een beschrijving van het reguliere werkproces, de aanpassingen die aan dit werkproces zijn gedaan om de doelen van de pilot te behalen en de wijzigingen die gedurende de pilot op basis van de ervaringen met het werkproces zijn doorgevoerd. Deze beschrijving vormde de basis voor interviews met de ketenpartners (zie verder).

Daarnaast is het monitoringformulier dat door de juridisch ondersteuners voor intern gebruik werd bijgehouden tot september 2019 bekeken. In dit formulier werd de 
zittingsdatum, of het een combi-zaak betreft, de hoeveelheid tijd die rechters en de juridische ondersteuning kwijt zijn aan de voorbereiding en uitwerking van de zaken en de duur van de zitting ingevuld. Deze gegevens zijn gebruikt door de rechtbank Rotterdam om kwantitatieve uitspraken te kunnen doen over de benodigde tijd voor voorbereiding, behandeling van de zaak en zittingsduur voor rechters en juridische ondersteuners. Daarnaast werd in het formulier bijgehouden of het een potentiële combi-zaak is vanuit het ZVHRR of de rechtbank, de uitspraken en of een zaak werd aangehouden. Deze gegevens zijn echter alleen voor het eerste jaar na start van huiselijk geweldzittingen binnen de pilot gestart, en niet dermate consequent bijgehouden om hier uitspraken over te doen over de gehele pilot. Het monitoringformulier bood wel inzicht in het werkproces bij de rechtbank en dienden als uitgangspunt voor de interviews.

\section{Interviews}

Gedurende de looptijd van de procesevaluatie hebben we op verschillende momenten interviews gehouden met betrokken ketenpartners bij de pilot. De eerste interviews hebben plaatsgevonden bij de start van het onderzoek (april 2019). In het najaar 2019 heeft een tweede ronde interviews plaatsgevonden met de rechtbank en de ketenpartners in het ZVHRR. Deze resultaten zijn teruggekoppeld in een reflectiebijeenkomst met de ketenpartners in januari 2020. Vervolgens zijn verdiepende interviews gehouden met rechters en zijn aanvullende vragen gesteld aan de ketenpartners. Tot slot zijn de bevindingen in maart 2020 teruggekoppeld tijdens een tweede reflectiebijeenkomst.

\section{Groepsinterview met projectorganisatie}

Bij aanvang van het onderzoek in april 2019 is een groepsinterview gehouden met de projectorganisatie (de projectleiders bij de rechtbank en het ZVHRR). Naast kennismaking is in het interview ingegaan op de doelen van de pilot, de activiteiten in de ontwikkelfase, de eerste ervaringen met het werkproces, wijzigingen dit tot dan toe zijn doorgevoerd in het werkproces en een eerste indruk van de mate waarin de doelen worden bereikt.

\section{Groepsinterview met dossiercoördinatoren}

Met de twee dossiercoördinatoren van de rechtbank Rotterdam is een interview gehouden over de werkwijze binnen de rechtbank vanaf de agendering van de potentiële combi-zaken op de huiselijk geweldzitting. Daarnaast is gevraagd naar ervaringen met het werkproces, ervaren knelpunten en mogelijke oplossingen.

\section{Groepsinterview met professionals rechtbank}

In najaar 2019 is een groepsinterview gehouden met de volgende professionals bij de rechtbank:

- De dossiercoördinatoren (twee) 
- Alle betrokken rechters bij de pilot (vijf)

- Juridische ondersteuners (drie)

- Projectleider organisatie

In dit groepsinterview zijn de volgende onderwerpen behandeld:

- Doelen van de pilot volgens de respondenten

- Wat gaat goed in het werkproces voor het bereiken van de doelen

- Wat kan beter voor het bereiken van de doelen

Telefonische interviews met advocaten, officieren van justitie en ketenpartners Tevens interviewden wij in het najaar 2019 drie advocaten die op een combi-zitting een cliënt bijstonden in een combi-zaak. Het ging om twee strafrechtadvocaten en één civielrechtelijke advocaat die degene bijstond die in de strafzaak terechtstond. In die interviews vroegen wij hen naar het doel van de pilot, wat goed en minder goed gaat tijdens de behandeling van een combi-zaak, de beleving van hun cliënt(en) en het hun cliënt(en) heeft opgeleverd.

Daarnaast spraken we met drie officieren van justitie over hun ervaringen met de behandeling van combi-zaken. Alle drie de officieren hadden zowel ervaring met de pilot vanuit ZSM/Veiligheidshuis als ervaring met de combi-zaken op de huiselijk geweldzittingen. Met hen bespraken wij eveneens het doel van de pilot, wat goed en minder goed gaat tijdens de behandeling van een combi-zaak en hoe integrale behandeling de praktijk tot stand komt.

Er zijn acht individuele semigestructureerde telefonische interviews gehouden met ketenpartners van ZSM en het ZVHRR die zowel vanuit de uitvoeringspraktijk als vanuit de projectcoördinatie bij de pilot betrokken waren:

- Vertegenwoordiger van het OM (één)

- Vertegenwoordiger van ZVHRR en VVHZHZ20 (twee)

- Vertegenwoordiger RN (één)

- Vertegenwoordiger van RvdK (één)

- Vertegenwoordiger van ATP (één)

In deze interviews kwamen de volgende onderwerpen aan bod:

- De rol van de verschillende ketenpartners in het werkproces

- De aanpassingen in het werkproces om tot integrale behandeling te komen

- De ervaren knelpunten

- De mate waarin de doelen van de pilot bereikt worden

Met één vertegenwoordiger van VT en de politie is een kort telefonisch gesprek gevoerd over de rol van VT in het werkproces en de ervaringen met het aanleveren

20 Gedurende de pilot is Zorg-en Veiligheidshuis Zuid-Holland Zuid bij de pilot betrokken geraakt. In dit rapport wordt gesproken van 'het Veiligheidshuis' als gerefereerd wordt naar het Zorg- en Veiligheidshuis Zuid-Holland Zuid (VHZHZ) en Zorg- en Veiligheidshuis Rotterdam-Rijnmond (VHRR) wordt bedoeld. Indien enkel wordt verwezen naar VHRR gaat het om afspraken die zijn gemaakt voordat $\mathrm{VHZHZ}$ bij de pilot was betrokken of ervaringen met de pilot die expliciet door de respondenten van VHRR zijn benoemd. 
van informatie. In het voorjaar van 2020 zijn via de mail of telefonisch aanvullende vragen over het werkproces en de ervaringen met wijzigingen in het werkproces gesteld aan de ketenpartners.

\section{Verdiepende interviews met rechters}

Om meer inzicht te krijgen in de integrale behandeling tijdens de zitting, zijn vier van de vijf betrokken rechters geïnterviewd over de integrale behandeling tijdens de zitting en de rechterlijke interventies die worden ingezet.

\section{Reflectiebijeenkomsten}

Om te reflecteren op de uitkomsten van het onderzoek organiseerden we twee reflectiebijeenkomsten met de relevante ketenpartners. Op 13 januari 2020 hielden wij een reflectiebijeenkomst met tien vertegenwoordigers van ZVHRR, VHZHZ, VT, ATP, RvdK, OM en de rechtbank Rotterdam. Tijdens deze reflectiebijeenkomst legden wij de bevindingen uit interviews en de documentenanalyse voor. We bespraken ervaren knelpunten in het werkproces en welke stappen in het werkproces aanscherping of aanpassing behoeven.

In maart 2020 organiseerden we een tweede reflectiebijeenkomst over wat de pilot de ketenpartners heeft opgeleverd, of de werkwijze in de pilot in de reguliere werkwijze kan worden opgenomen en/of opschaling naar andere arrondissementen aan de orde was. De oorspronkelijk geplande bijeenkomst waar vertegenwoordigers van zes van de acht vertegenwoordigers aan konden deelnemen, ging niet door vanwege de maatregelen die in Nederland op dat moment werden ingezet voor de bestrijding van het COVID-19 virus. Er heeft vervolgens een videobijeenkomst plaatsgevonden met vertegenwoordigers van de rechtbank en het ATP. Vertegenwoordigers van het OM, RvdK, RN, ZVHRR, ZVHZHZ en VT zijn telefonisch geïnterviewd.

\section{Analyse tijdsbesteding}

Om inzicht te krijgen in de tijdsbesteding van de ketenpartners in de pilot en het werkproces hebben we de personele inzet op basis van ureninzet door het ZVHRR en de rechtbank Rotterdam geanalyseerd. We maken daarbij onderscheid tussen ureninzet voor de coördinatie van de pilot en voor de uitvoering van het werkproces. De ureninzet is tijdens de pilot niet systematisch geregistreerd door het ZVHRR. We hebben alleen inzicht in de gemiddelde inzet van de projectleider.

\section{Bijwonen van zittingen}

We woonden twee huiselijk geweldzittingen bij (in juni en november 2019). Omdat pas kort van tevoren duidelijk is of op een huiselijk geweldzitting een combi-zaak wordt behandeld en toestemming nodig is van de partijen om de zitting bij te mogen wonen, was het niet haalbaar om meer combi-zaken bij te wonen. Op de twee bijgewoonde zittingen werden in totaal drie combi-zaken behandeld. Bij de combizaak in november 2019 hebben wij het civiele deel van een zaak niet mogen 
bijwonen. Op de huiselijk geweldzitting worden naast de combi-zaken ook huiselijk geweldzaken behandeld waarbij geen sprake is van het combineren van de strafzaak met een civiele procedure (zie paragraaf 3.2.3). Het doel van de observaties op de zittingen was inzicht krijgen in de integrale behandeling van de combi-zaken en de rechterlijke interventies. Om voldoende casuïstiek te verzamelen en te verhelderen wat een integrale behandeling inhoudt, is daarop besloten om in verdiepende telefonische interviews met de betrokken rechters casuïstiek door te spreken (zie verdiepende interviews rechters boven).

\section{Enquête onder betrokkenen advocaten}

Om de ervaringen van advocaten met de huiselijk geweldzitting meer inzichtelijk te krijgen, stuurde de rechtbankadvocaten standaard na een huiselijk geweldzitting binnen de pilot een enquête. Daarin werden zij gevraagd of zij bekend waren met de pilot en of de zaak van hun cliënt(en) binnen de pilot werd behandeld, of er daadwerkelijk sprake was van een gecombineerde behandeling en wat hun ervaringen waren met de gecombineerde behandeling. Het is niet bekend hoeveel enquêtes de rechtbank heeft verstuurd. 32 enquêtes waren voldoende ingevuld om te analyseren voor de procesevaluatie. Ook is niet bekend hoeveel van de enquêtes betrekking hebben op een combi-zaak of een andere zaak op de huiselijk geweldzitting.

\section{Analyse van de doorlooptijden}

Door de rechtbank is een databestand aangeleverd met de doorlooptijden (pleegdatum tot datum van uitspraak) van achttien combi-zaken die op een huiselijk geweldzitting van de pilot zijn behandeld. Deze doorlooptijden zijn vergeleken met de doorlooptijden uit de voormeting van de rechtbank (zie 1.6). In de voormeting zijn de doorlooptijden van veertien huiselijk geweldzaken die in 2015 en 2016 door een politierechter zijn behandeld op de rechtbank Rotterdam onderzocht. De zaken in de voormeting waren zaken waarbij naast de strafzaak ook een civiele procedure in het gezin liep. Deze zaken zijn vergelijkbaar met de (potentiële) combi-zaken die op de huiselijk geweldzitting van de pilot worden geagendeerd.

\section{Wijzigingen in de onderzoeksaanpak gedurende het onderzoek}

Aanvankelijk was de verwachting dat wij inzicht zouden krijgen in de zittingsverslagen die de vijf rechters van de zaken die zij op de combi-zittingen behandelen, bijhouden. Op basis van de zittingsverslagen wilden wij inzicht krijgen in de uitspraken van de rechters en de overwegingen om te komen tot een uitspraak. Dit moest inzicht geven in de integrale behandeling, of de uitspraken van rechters in de verschillende juridische zaken op elkaar zijn afgestemd en op de problematiek van het gezin. Het bleek vanuit de rechtbank Rotterdam bij nader inzien niet mogelijk om de verslagen in te zien. Om hier meer inzicht in te krijgen, hebben we zittingen bijgewoond en verdiepende interviews gehouden met vier van de vijf rechters die bij de pilot betrokken zijn. 


\section{Procesevaluatie}

De procesevaluatie geeft antwoord op de volgende onderzoeksvragen:

Welke organisatorische en logistieke voorzieningen zijn getroffen door het ZVHRR en de rechtbank om de integrale behandeling van huiselijk geweldzaken mogelijk te maken? En hoe is hier in de praktijk invulling aan gegeven?

In de procesevaluatie hebben we onderzocht welke aanpassingen zijn doorgevoerd in het reguliere werkproces voor de behandeling van huiselijk geweldstrafzaken bij de politierechter, bij de start en gedurende de looptijd van de pilot op basis van ervaringen met het werkproces. De aanpassingen in het werkproces zijn in de voorbereidingsfase van de pilot door de projectorganisatie bepaald op basis van de voormeting. Daarnaast hebben we een analyse gemaakt van de tijdsbesteding op basis van ureninzet van het ZVHRR en de rechtbank.

\subsection{Voorbereiding van de pilot}

In de voorbereidingsfase hebben de rechtbank, ZSM en Veiligheidshuis overlegd gepleegd over de invulling van de pilot en is een voormeting uitgevoerd. Dit heeft geresulteerd in aanpassingen in het reguliere werkproces voor huiselijk geweldzaken. Daarnaast is er via verschillende kanalen gecommuniceerd over de pilot om draagvlak te creëren bij advocaten, verdachten en slachtoffers: via Rechtspraak.nl en Huiselijkgeweld.nl. Er is een factsheet onder deelnemers van het casusoverleg, medewerkers van ZSM, raadsvertegenwoordigers van de RvdK en medewerkers van het ATP verspreid met informatie over de geïntegreerde aanpak. In het circulaire advocatenblad is informatie over de pilot opgenomen.

Ook zijn verschillende trainingen gegeven ten behoeve van de pilot. Zo werd in mei 2018 een workshop verzorgd door twee rechters voor OM en rechters over huiselijk 
geweld. Juridische ondersteuners van de rechtbank volgden daarnaast een cursus over huiselijk geweld. Ook kregen rechters en juridische ondersteuners een training beschikking schrijven voor civiele familiezaken. Door een mediation-functionaris van de rechtbank Rotterdam is daarnaast een presentatie gegeven aan de betrokken rechters en juridische ondersteuners waarin verteld werd wat een mediation-traject inhoudt en hoe mediation in de pilot kan worden ingezet.

\subsection{Aanpassingen aan het reguliere werkproces}

In deze paragraaf beschrijven we de aanpassingen in het reguliere werkproces voor de behandeling van huiselijk geweldzaken die zijn doorgevoerd om de doelen van de pilot te behalen. Het is eigen aan een pilot dat op basis van de ervaringen met het werkproces de werkwijze wordt aangepast.

\subsubsection{Regulier werkproces}

Uitgangspunt van de pilot is het reguliere werkproces voor de behandeling van huiselijk geweldzaken in het arrondissement Rotterdam die door de politierechter worden behandeld (zie voor gedetailleerde beschrijving bijlage 1). Het werkproces start op het moment dat na aangifte van huiselijk geweld de verdachte door de politie wordt verhoord, en eindigt met de behandeling van de zaak door de politierechter. ${ }^{21}$

Wanneer een verdachte wordt aangehouden voor huiselijk geweld wordt de verdachte door de politie verhoord. De informatie uit het inhoudelijke en sociale verhoor ${ }^{22}$ wordt samen met informatie van VT, RvdK, RN en Jeugdbescherming op het ATP verzameld, wat in het arrondissement Rotterdam onderdee ${ }^{23}$ is van ZSM/ ZVHRR. De ketenpartners van ZSM/ZVHRR maken op basis van die informatie een

21 In de afdoeningsbeslissing kan de officier van justitie ook kiezen voor een strafbeschikking. In de pilot richten wij ons echter op huiselijk geweldzaken die normaliter door de politierechter worden behandeld.

22 Tijdens het sociaal verhoor worden vragen gesteld over de persoonlijke situatie van de verdachte. In het inhoudelijk verhoor wordt ingegaan op het strafbare feit waarvoor de verdachte is aangehouden.

23 Het reguliere werkproces in Rotterdam wijkt af van de rest van Nederland. Kenmerkend aan dat werkproces in Rotterdam is dat, doordat ZSM op dezelfde locatie als het ZVHRR is ondergebracht, er al voor de pilot sprake was van samenwerking en informatie-uitwisseling tussen de verschillende ketenpartners (RvdK, RN, VT, Jeugdbescherming, OM en ZVHRR/ZVHZHZ). 
inschatting van de complexiteit van de casus. Als op basis van de triagecriteria ${ }^{24}$ van het Veiligheidshuis wordt vastgesteld dat er sprake is van een complexe casus, wordt de zaak tijdens het casusoverleg van het Veiligheidshuis besproken. De officier van justitie op ZSM neemt op basis van de informatie die door de ketenpartners is verzameld, een beslissing over de afdoening van de strafzaak. Naast het seponeren van de zaak, kan de officier van justitie kiezen om de strafzaak direct op ZSM of op een OM hoorzitting af te doen of de verdachte te dagvaarden en daarmee de strafzaak door een politierechter of meervoudige kamer te laten behandelen. Indien de officier van justitie dat nodig acht, vraagt hij/zij RN een adviesrapportage over de verdachte op te stellen ten behoeve van de zitting. Complex getriageerde casussen worden daarnaast besproken tijdens het casusoverleg bij het ZVHRR. ${ }^{25}$

\subsubsection{Werkproces bij aanvang van de pilot}

Om de doelen van de pilot te bereiken, zijn in het reguliere werkproces aanpassingen doorgevoerd. De aanpassingen hebben enerzijds betrekking op het detecteren van potentiële combi-zaken voor de huiselijk geweldzitting in de pilot en anderzijds op de voorbereiding en behandeling van de zaken op de huiselijk geweldzitting.

\section{Aanpassingen voor (eerdere) informatie-uitwisselingen en het detecteren van potentiële combi-zaken}

- In aanloop naar de afdoeningsbeslissing wordt er informatie van de RvdK en de politie verzameld op het ATP van ZSM/ZVHRR. Na agendering op de huiselijk geweldzitting wordt standaard een adviesrapportage bij RN opgevraagd. De RN vraagt informatie op bij VT. Daarnaast is de afspraak tussen ZVHRR en RN gemaakt om de aanlevertermijn van de adviesrapportages te verkorten van tien naar acht weken.

- De officier van justitie op ZSM beslist of sprake is van een potentiële combi-zaak. In dat geval wordt de zaak op de pilot huiselijk geweldzitting gepland. Daarnaast wordt de zitting aangevuld met huiselijk geweldzaken waar geen civiele zaak

24 "Er is bij huiselijk geweld sprake van complexe casuïstiek als er na een strafbaar feit sprake is van samenloop van strafrecht en/of bestuursrecht en/of zorg en er problemen zijn op twee of meer leefgebieden en er daarnaast sprake is van één van de onderstaande aanvullende criteria: 1) Het risico op herhaling van huiselijk geweld en/of dreiging geweld is zeer groot en er moet met urgentie een veiligheidsplan worden opgesteld, 2) Er is sprake van een intimite terrorist [d.w.z. een dader van huiselijk geweld waarbij de dader het slachtoffer probeert te domineren door controle en macht uit te oefen, psychisch geweld en dreigen met lichamelijk geweld], 3) Minderjarige kinderen zijn (direct) betrokken als dader, slachtoffer of getuige, 4) Dader of slachtoffer kampen met specifieke persoonsgerichte problemen zoals verslaving, LVB, psychiatrie 5) Er is een huisverbod opgelegd naar aanleiding van een geplande screening vanuit het weegteam bij kindermishandelingszaken, 6) Er is sprake van een potentiële stalkingszaak of van een concrete (ernstige) stalkingszaak, waarbij mogelijk Aware [is een mobiel alarmsysteem] van belang wordt geacht, 7) Er is bij de vraagstelling duidelijk expertise nodig vanuit meerdere ketenpartners." Zie voetnoot 24 , via ZVHRR. 
loopt en ook geen vermoeden bestaat dat er meer aan de hand is.

- Alle potentiële combi-zaken worden op ZSM/Veiligheidshuis als complex getriageerd. ${ }^{26}$ Hierdoor worden alle potentiële combi-zaken besproken tijdens het casusoverleg op het Veiligheidshuis. Het doel van deze stap is om potentiële combi-zaken te monitoren op de voortgang om na te gaan of de zaken daadwerkelijk resulteren in een combi-zaak.

\section{Aanpassing voor de integrale behandeling op de combi-zaken}

- Er is een vaste middag bestemd voor de pilot huiselijk geweldzitting waarop meer tijd beschikbaar is voor de behandeling van de zaken dan op de politierechterzitting. Op de vaste pilot huiselijk geweldzitting worden combi-zaken en andere huiselijk geweldzaken (zonder civiele zaak behandeld) geagendeerd. Er is een uur uitgetrokken voor combi-zaken en een half uur voor huiselijk geweldzaken zonder civiele zaak.

- De dossiercoördinator van de rechtbank gaat voor geagendeerde potentiële combi-zaken na of de strafzaak en civiele zaak zittingsrijp zijn en wat betreft termijnen gecombineerd kunnen worden. Alle op ZSM verzamelde informatie wordt aan de dossiercoördinator gestuurd. Waar nodig, wordt extra informatie opgevraagd bij RvdK en/of Jeugdbescherming. Daarnaast wordt, via de advocaat, toestemming gevraagd aan het slachtoffer en de verdachte voor de integrale behandeling van de straf- en civiele zaken op de pilot huiselijk geweldzitting

- Een vaste poule van vijf rechters met kennis van strafrecht en familierecht en/of jeugdrecht en zittingservaring die alle zaken op de pilot huiselijk geweldzitting behandelen.

- Twee dossiercoördinatoren en een vast poule van vijf juridisch ondersteuners die allemaal meerdere rechtsgebieden kunnen ondersteunen.

- Extra tijd tijdens de huiselijk geweldzitting in de pilot.

\section{Aanpassing voor de snellere behandeling van de strafzaak}

- De potentiële combi-zaak worden drie maanden na behandeling op ZSM geagendeerd op de pilot huiselijk geweldzitting.

\subsubsection{Aanpassingen werkproces gedurende pilot}

\section{Aanpassingen ter bevordering van de detectie van combi-zaken}

Gedurende de pilot bleef het aantal combi-zaken achter bij de verwachting van gemiddeld twee zaken per week (zie4.3). Om meer potentiële combi-zaken te detecteren en om het combineren van de strafzaak met een civiele zaak te bevorderen, zijn gedurende de pilot de volgende acties genomen: 
- Tussen het ZVHRR en politie Rotterdam-Rijnmond is de afspraak gemaakt om bij opname van de aangifte en afname van het sociaal verhoor aandacht te besteden aan eventuele echtscheidingsproblematiek en de betrokkenheid van kinderen. De informatie over echtscheidingsproblematiek was niet of pas in een later stadium bekend, wat de detectie op ZSM van huiselijk geweldzaken met echtscheidingsproblematiek bemoeilijkte. Met deze aanpassing wil het ZVHRR bereiken dat bij ATP informatie over eventuele echtscheidingsproblematiek of kinderen in het gezin beschikbaar is. Hierdoor wordt de detectie van potentiële combi-zaken bevorderd.

- Volgens de rechtbank was een van de redenen waarom het aantal combi-zaken lager was dan verwacht de onwetendheid bij advocaten en hun cliënten over de mogelijkheid van een combi-zitting, en wat de voordelen waren van het combineren van de strafzaak met civiele zaken. Hierdoor worden civiele zaken niet altijd aanhangig gemaakt. Er is besloten dat de verdachte bij dagvaarding een brief ontvangt waarin wordt aangegeven dat zijn/haar zaak op een huiselijk geweldzitting is gepland en dat het mogelijk is op die zitting een civiele zaak met een strafzaak te combineren. Door te wijzen op die mogelijkheid verwacht men dat - indien van toepassing - civiele verzoeken worden ingediend.

- In het begin van de pilot werden ook zaken op de huiselijk geweldzitting geplaatst waarvan op voorhand duidelijk was dat er geen civiele zaak aanhangig was gemaakt en ook geen vermoeden was dat er in het civiele kader problemen speelden. De criteria voor het plaatsen van een zaak op de huiselijk geweldzitting zijn daarom strikter gehanteerd. Alleen nog huiselijk geweldzaken waarvan duidelijk is dat zij met een civiele zaak gecombineerd kunnen worden, én huiselijk geweldzaken waarin het vermoeden bestaat dat er meer aan de hand is al dan niet met uitzicht op een civiele zaak, worden nog op de huiselijk geweldzitting geplaatst.

- De RvdK wordt wanneer een huiselijk geweldzaak als potentiële combi-zaak is aangemerkt en er kinderen zijn in het gezin, gemaild met de namen van de kinderen om na te gaan of er al een verzoek voor een raadsonderzoek is ingediend. Als de kinderen op de wachtlijst staan, wordt het raadsonderzoek vervroegd uitgevoerd zodat het rapport beschikbaar is op de pilot huiselijk geweldzitting. Op deze manier vormen de lange wachtlijsten bij de RvdK geen belemmering voor het combineren van jeugdzaken met de strafzaak.

- Omdat het aantal combi-zaken tegenviel, is in februari 2020 besloten dat verdachten en slachtoffers die tijdens hun verhoor kenbaar hebben gemaakt problemen binnen het civielrechtelijke kader te hebben en het voornemen hebben een civiel verzoek in te dienen (bijv. het voornemen om te gaan scheiden), actief worden benaderd. Een medewerker vraagt, op verzoek van een medewerker van ZVHRR, bij de verdachte na of hij/zij bekend is met de mogelijkheid van het combineren van zaken op de huiselijk geweldzitting. Slachtoffers worden benaderd door SHN, eveneens op verzoek van een medewerker van ZVHRR. 


\section{Aanpassingen in de monitoring van potentiële combi-zaken}

Met betrekking tot het monitoren ten behoeve van de detectie en voortgang van potentiële combi-zaken en geagendeerde huiselijk geweldzaken met onderliggende problematiek, is er gedurende de pilot een aantal wijzigingen geweest.

- Het casusoverleg bleek niet het geschikte moment om potentiële combi-zaken te monitoren om twee redenen: 1) niet alle potentiële combi-zaken waren complex genoeg voor het doel waarvoor het casusoverleg is ingericht en 2) het ZVHRR had onvoldoende zicht op of een potentiële combi-zaak uiteindelijk wel of geen combi-zaak werd. Daarop is besloten om het monitoren tussen juli 2019 en februari 2020 in zijn geheel te beleggen bij de dossiercoördinator van de rechtbank en uit te breiden. De dossiercoördinator gaat voor alle potentiële combi-zaken na of de civiele zaak aanhangig is gemaakt en wat betreft termijnen gecombineerd kan worden met de strafzaak.

- Daarnaast is er door de rechtbank Rotterdam een query-lijst ontwikkeld waarin alle huiselijk geweldzaken en civiele zaken zijn opgenomen, om eventuele overlap van zaken te detecteren die bij het ZSM/Veiligheidshuis gemist zijn.

- Met het geheel beleggen van de monitoring bij de rechtbank bleek dat de rechtbank niet op de hoogte is van wat er bij de de ketenpartners in de 'pijplijn' zit wat betreft eventuele problemen die spelen in het civiel rechtelijk kader, maar waarvoor nog geen civiele zaak aanhangig is gemaakt. De reden hiervoor is dat de rechtbank het 'sluitstuk' is van de keten en onafhankelijk van ZSM/

Veiligheidshuis opereert. Bovendien merkten rechters dat ontwikkelingen die zich in aanloop naar de huiselijk geweldzitting hadden voorgedaan soms in het strafen civiele dossier ontbraken. Daarop is in februari 2020 besloten, om naast de monitoring bij de rechtbank, ook monitoring bij het Veiligheidshuis te beleggen. Deze monitoring houdt in dat één medewerker van het ZVHRR een aantal checks uitvoert om potentiële combi-zaken te detecteren en potentiële combi-zaken te monitoren op voortgang. ${ }^{27}$

27 Het betreft de volgende checks: 1) Check bij de RvdK: de medewerker monitort of de RvdK het raadsonderzoek van de wachtlijst haalt en prioriteit geeft om eerder uit te voeren (zie onder Raad voor de Kinderbescherming). Als het raadsonderzoek niet eerder wordt uitgevoerd, koppelt de medewerker van het Veiligheidshuis dit terug aan het OM. 2) Check bij Jeugdbescherming: er wordt door de medewerker nagegaan of er nog nieuwe meldingen zijn die nog niet bekend zijn. 3) Check bij RN: de medewerker checkt of het adviesrapport van RN ten behoeve van de combizitting gereed is. En als de verdachte in het proces-verbaal kenbaar heeft gemaakt problemen binnen het civielrechtelijke kader te hebben en het voornemen heeft om een civiel verzoek in te dienen, verzoekt de officier van justitie de medewerker om contact op te nemen met RN. De medewerker vraagt RN om bij de verdachte na te vragen of hij/zij een civiel verzoek wilt en gaat indienen. 4) Check bij SHN: indien het slachtoffer in het proces-verbaal kenbaar heeft gemaakt dat hij/zij problemen binnen het civielrechtelijke kader heeft en het voornemen heeft een civiel verzoek in te dienen, verzoekt de officier van justitie de medewerker om contact op te nemen met $\mathrm{SHN}$. De medewerker vraagt SHN om bij het slachtoffer na te vragen of hij/zij nog een civiel verzoek wilt en gaat indienen. 5) Check bij het OM: wekelijks heeft de medewerker contact met de parketsecretaris van het $\mathrm{OM}$ over nieuw geagendeerde potentiële combi-zaken om te komen tot een actuele werklijst. Daarnaast gaat de medewerker na of er in het proces-verbaal of in de verklaring van het slachtoffer/de verdachte informatie staat die niet in het registratiesysteem van het Veiligheidshuis is opgenomen. 6) Check bij rechtbank Rotterdam: de medewerker checkt elke twee weken of er nieuwe combi-zaken gepland kunnen worden en of er wijzigingen zijn in de al geagendeerde combi-zaken. 


\subsubsection{Werkproces einde pilot}

Het werkproces aan het eind van de pilot is samengevat weergegeven in figuur 3.1. De wijzigingen die gaandeweg de doorlooptijd van de pilot werden doorgevoerd, zijn weergegeven in de gekleurde blokken. Het gaat om het werkproces met peildatum februari 2020. Voor een uitgebreide toelichting per stap in het werkproces, verwijzen wij naar bijlage 1 .

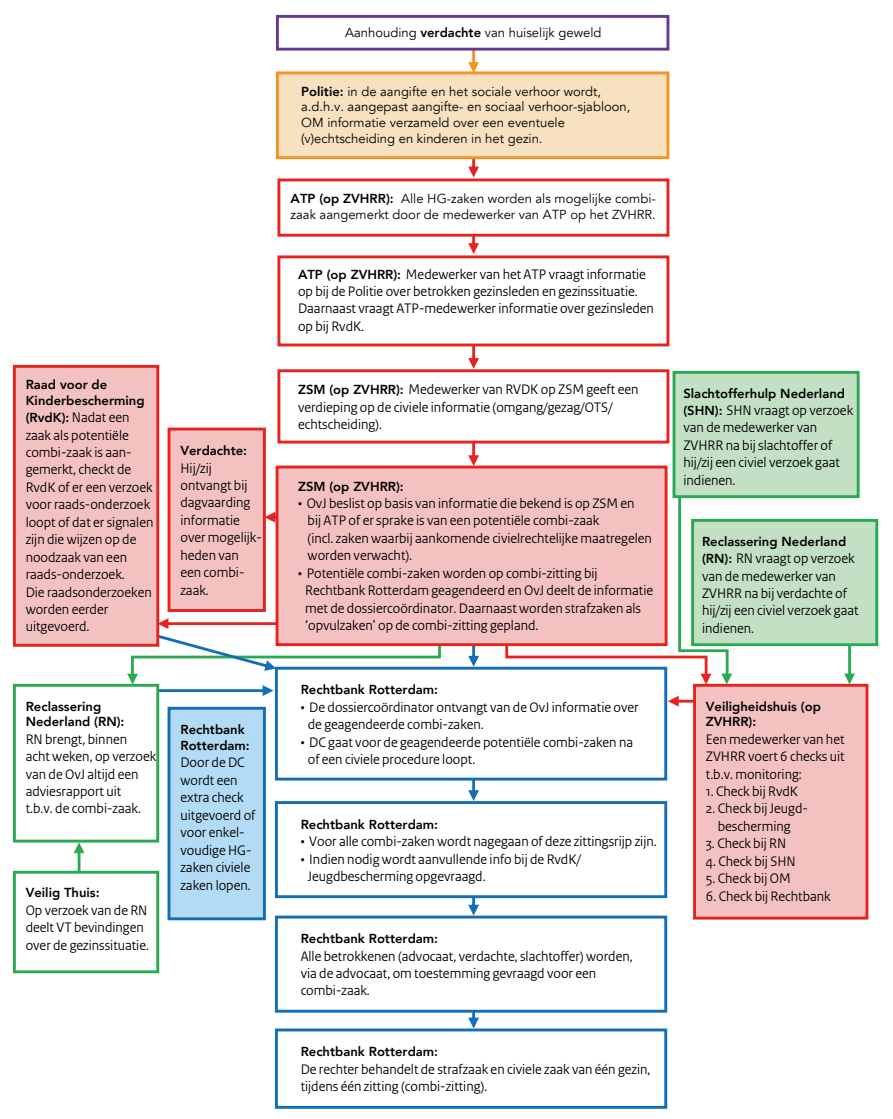

Figuur 3.1 Werkproces pilot geïntegreerde aanpak huiselijk geweld (februari 2020) 


\subsection{Ervaring met en waardering van het werkproces}

Over het werkproces dat in de eindfase van de pilot werd aangehouden, zijn de samenwerkingspartners positief. Over het algemeen worden de stappen in het werkproces uitgevoerd zoals bedoeld. De betrokken partijen weten elkaar goed te vinden en de lijnen zijn kort. Met name in de beginfase van de pilot bleken niet alle medewerkers van de verschillende betrokken organisaties goed op de hoogte van het doel van de pilot en het werkproces. Voorlichting aan de medewerkers heeft eraan bijgedragen dat alle betrokken organisaties uiteindelijk goed op de hoogte waren van het doel, het werkproces en wat andere organisaties doen.

Het feit dat ZSM en Veiligheidshuis Rotterdam op dezelfde locatie zijn ondergebracht, maakt dat al vóór de pilot de onderlinge samenwerking goed was en de lijnen kort. Door de pilot weet men elkaar nog beter te vinden en zijn de lijnen korter dan voorheen. Het is met name de verbeterde samenwerking en afstemming tussen $\mathrm{OM}, \mathrm{RvdK}$, RN en het Veiligheidshuis en de rechtbank Rotterdam zien deze partijen als meerwaarde van de pilot. Waar RvdK, RN en het Veiligheidshuis, en in mindere mate OM, voorheen weinig zicht hadden op de werkwijze van de rechtbank en de rechtbank als een relatief gesloten organisatie zagen, is met de pilot meer afstemming met de rechtbank. De rechtbank beaamt dit. Zo heeft de dossiercoördinator inmiddels zelf korte lijnen met de verschillende samenwerkingspartners.

\section{Logistieke en organisatorische aandachtspunten in het werkproces}

Er zijn ook een aantal ervaringen met het werkproces opgedaan die nog aandacht behoeven, en aandachtspunten zijn voor het eventueel voortzetten van de pilot. Eén van de aandachtspunten is de monitoring van potentiële combi-zaken en huiselijk geweldzaken waar nog geen civiele zaak speelt, maar waar wel mogelijk meer aan de hand is. De aanpassing in het werkproces om naast een monitoringsmoment bij de rechtbank ook een monitoringsmoment bij het ZVHRR te beleggen, is volgens respondenten van het Veiligheidshuis, OM, ATP en de rechtbank Rotterdam belangrijk. Op die manier kunnen ontwikkelingen in potentiële combi-zaken die zich in de aanloop naar de zitting voordoen en ontwikkelingen in huiselijk geweldzaken waar (nog) geen civiele zaak loopt, worden bijgehouden. Omdat deze aanpassing echter pas in april 2020 in de praktijk is gebracht, is het nog te vroeg om iets te zeggen over de uitvoeringspraktijk van deze wijziging.

Een tweede aandachtspunt betreft het prioriteren van raadsonderzoeken voor potentiële combi-zaken door de RvdK. Deze wijziging is in oktober 2019 doorgevoerd, wat het te vroeg maakt om uitspraken te doen over de uitvoeringspraktijk van deze wijziging. Bovendien worden sinds de maatregelen voor de bestrijding van het COVID-19 virus vanaf half maart geen combi-zittingen meer 
gepland. Ook zijn vanaf die tijd geen potentiële combi-zaken meer aangemeld door het ZVHRR.

Een derde aandachtspunt betreft de vorderingen van het slachtoffer, die daarbij ondersteund wordt door SHN. In die vordering vraagt het slachtoffer om een schadevergoeding naar aanleiding van het strafbare feit. Geïnterviewde rechters, juridische ondersteuners en advocaten geven aan soms moeite te hebben met de vorderingen die worden ingediend, omdat die niet altijd in verhouding staan tot wat zich heeft afgespeeld. Rechters zijn echter wel genoodzaakt de vordering tijdens de combi-zitting te bespreken, wat soms veel tijd in beslag neemt. Daarnaast worden de vorderingen soms net vóór of tijdens de zitting ingebracht, waardoor vlak voor of tijdens de zitting olie op het vuur wordt gegooid door de advocaat van het slachtoffer. Deze vorderingen staan volgens een geïnterviewde advocaat de dialoog die een rechter tijdens een combi-zitting probeert te creëren in de weg. De rechters en juridische ondersteuning hebben het idee dat Slachtofferhulp Nederland onvoldoende is voorgelicht over het doel en de opzet van de combi-zittingen.

Een vierde aandachtspunt is de informatie-uitwisseling tussen VT en RN. Het delen van informatie van VT met RN is geen staande praktijk gebleken. Dit geven respondenten van het Veiligheidshuis, RN, RvdK en VT aan in de interviews en tijdens de reflectiebijeenkomst in januari 2020. Volgens de respondent van VT wordt er voor combi-zaken niet altijd om informatie gevraagd door RN. Een reden daarvoor is, volgens de respondent, een gebrek aan tijd aan de zijde van RN. De respondent van VT gaf tijdens de reflectiebijeenkomst aan dat in plaats van de informatiedeling tussen VT en de rechtbank via RN te laten verlopen, ook gekozen kan worden voor een route via de politie of OM. Respondenten van RN en OM zijn echter van mening dat de keuze voor een andere route niet nodig is, omdat zij in najaar 2019 en begin 2020 steeds vaker informatie zien van VT in de adviesrapportages van RN. Rechters vinden het lastig te zeggen of er inderdaad vaker dan in het begin van de pilot, informatie van VT in de adviesrapportages van RN beschikbaar is. Een respondent van het OM geeft aan wel problemen te ondervinden met specifiek het VT ZuidHollland Zuid voor het tijdig aanleveren van informatie.

\section{Niet haalbare procesafspraken}

Naast de aandachtspunten zijn er ook stappen in het werkproces die in de praktijk niet haalbaar zijn gebleken, maar niet zozeer als knelpunt of aandachtspunt worden ervaren door de betrokken samenwerkingspartners.

Een eerste punt heeft betrekking op de afspraak met de politie om het sjabloon of protocol voor afname van een aangifte en sociaal verhoor aan te passen. Met deze wijziging zouden verdachten standaard worden gevraagd naar echtscheidingsproblematiek en betrokkenheid van kinderen. Van een respondent van de politie blijkt 
dat er geen vraag aan het sjabloon is toegevoegd over een (v)echtscheiding en betrokkenheid van kinderen, en dat ook in het protocol niet is opgenomen dat de desbetreffende agent hier standaard naar vraagt. Omdat er met geautomatiseerde systemen wordt gewerkt, is het niet eenvoudig de sjablonen en protocollen aan te passen. De portefeuillehouder huiselijk geweld bij de politie heeft in gesprekken met de doelgroepen coördinatoren in de districten wel gewezen op het belang van het sociaal verhoor in relatie tot deze pilot. Volgens respondenten van het OM en het ZVHRR vinden officieren van justitie in de processen-verbaal wel informatie over een eventuele (v)echtscheiding en de betrokkenheid van kinderen. Als die informatie in een proces-verbaal is opgenomen, komt dit volgens een respondent van de politie ofwel doordat de verdachte zelf die informatie heeft ingebracht, ofwel omdat de agent signalen heeft opgevangen over een (v)echtscheiding en kinderen en hier specifiek op heeft doorgevraagd.

Een tweede punt betreft de verkorte aanlevertermijn voor adviesrapportages van RN (van tien naar acht weken) die niet altijd haalbaar is. In de beginfase van de pilot is tussen de voormalige directeur van RN en het ZVHRR de afspraak voor een kortere aanlevertermijn gemaakt. Volgens respondenten van het Veiligheidshuis had die afspraak door het OM vastgelegd moeten worden, maar is dat niet gebeurd.

Daardoor worden de adviesrapporten over het algemeen niet binnen de verkorte termijn aangeleverd, maar binnen de gebruikelijke tien weken. Volgens een respondent van $\mathrm{RN}$ is een capaciteitsgebrek de reden dat het niet altijd lukt om een adviesrapport sneller op te leveren. Het hangt het af van de complexiteit van de casus en hetgeen met de officier van justitie is afgesproken of het adviesrapport binnen acht weken klaar is. Volgens een respondent van het OM levert het niet halen van de verkorte termijn in de praktijk weinig problemen op, zolang het adviesrapport op zitting beschikbaar is.

\subsection{Analyse tijdsbesteding}

In de analyse van de tijdsbesteding is gekeken naar de personele capaciteit in de vorm van urenbesteding die vanuit ZVHRR en de rechtbank nodig was voor het opzetten en coördineren van de pilot en naar de ureninzet die nodig is voor de detectie van combi-zaken, het voorbereiden en uitwerken van de combi-zittingen en de zittingsduur.

\subsubsection{Tijdsbesteding ontwikkeling en coördinatie pilot}

De ureninzet voor de ontwikkeling en de coördinatie van de pilot gedurende de looptijd van de pilot is weergegeven in tabel 3.1.

De uren besteed aan de ontwikkeling zijn de uren voor de voorbereiding van de pilot: 
overleg, communicatie over de pilot en trainingen voor medewerkers van de rechtbank en OM (zie 3.1)

De ureninzet van het ZVHRR is niet geregistreerd. Alleen de inzet van de projectleider van het ZVHRR is bekend. Hij was gemiddeld drie uur per week kwijt aan de ontwikkeling van de pilot en gedurende de looptijd van de pilot één uur per week aan coördinatie. De totale ureninzet tussen oktober 2017 en januari 2020 is ongeveer 170 uur. De tijdsinzet van de ketenpartners in het ZVHRR en ZVHZH is niet vastgelegd. We kunnen geen uitspraken doen over extra ureninzet van de ketenpartners. De aandacht voor potentiële combi-zaken is onderdeel van reeds bestaande overleggen. Wel zijn afspraken gemaakt over het extra en eerder aanleveren van informatie. De tijdsbesteding hiervoor is niet in kaart gebracht.

Voor de projectcoördinatie, de uitvoering van de voormeting en het opstellen van het werkproces is de tijdsbesteding, in arbeidsuren, door de rechtbank bijgehouden. Dit zijn uren gemaakt in de periode september 2017 en mei 2018.

Tabel 3.1 Totale en gemiddelde tijdsbesteding van de projectleiding vanuit de rechtbank Rotterdam en ZVHRR aan begeleiding pilot, tussen september 2017 en mei 2018.

\begin{tabular}{llll}
\hline & $\begin{array}{l}\text { Totaal } \\
\text { aantal uren }\end{array}$ & $\begin{array}{l}\text { Gemiddeld aantal } \\
\text { uren per maand }\end{array}$ & $\begin{array}{l}\text { Gemiddeld } \\
\text { aantal uren } \\
\text { per week }\end{array}$ \\
\hline $\begin{array}{l}\text { Rechtbank } \\
\begin{array}{l}\text { Projectleiding rechtbank } \\
\text { (3 personen) }\end{array}\end{array}$ & 458 & 50,8 & 12,7 \\
$\begin{array}{l}\text { Dossiercoördinator } \\
\begin{array}{l}\text { Afstemming met } \\
\text { administratieve teams }\end{array}\end{array}$ & 192,5 & 21,4 & 5,3 \\
\hline $\begin{array}{l}\text { Totaal } \\
\text { ZHVRR }\end{array}$ & 63,0 & 0,9 & 0,2 \\
Ontwikkeling pilot & 96,0 & 74,8 & 18,7 \\
\hline
\end{tabular}

$1 \quad$ ZVHRR heeft de urenbesteding niet wekelijks bijgehouden. Voor het berekenen van het aantal uren zijn we uitgegaan van een ontwikkelperiode van acht maanden (32 weken). 
Daarnaast is door de rechtbank Rotterdam en het ZVHRR bijgehouden hoeveel tijd is gespendeerd aan de projectcoördinatie gedurende de uitvoering van de pilot (juni 2018 tot januari 2020).

Tabel 3.2 Totale en gemiddelde tijdsbesteding van de projectorganisatie van de rechtbank Rotterdam28 en ZVHRR aan begeleiding pilot, tussen juni 2018 en januari 2020.

\begin{tabular}{llll}
\hline & $\begin{array}{l}\text { Totaal } \\
\text { aantal uren }\end{array}$ & $\begin{array}{l}\text { Gemiddeld aantal } \\
\text { uren per maand }\end{array}$ & $\begin{array}{l}\text { Gemiddeld } \\
\text { aantal uren } \\
\text { per week }\end{array}$ \\
\hline Rechtbank & & 39,7 & \\
$\begin{array}{l}\text { Projectleiding rechtbank } \\
\text { (3 personen) }\end{array}$ & 793,9 & & \\
$\begin{array}{l}\text { Afstemming rechters en } \\
\text { juridische ondersteuning }\end{array}$ & & 2,4 & 0,6 \\
$\begin{array}{l}\text { (tot zeven personen) } \\
\text { Totaal }\end{array}$ & 64,0 & 42,9 & 10,7 \\
$\begin{array}{l}\text { ZHVRR } \\
\text { Coördinatie gedurende }\end{array}$ & 80 & 4 & 1 \\
looptijd pilot & 857,9 & 4 & \\
\hline
\end{tabular}

2 ZVHRR heeft de urenbesteding niet wekelijks bijgehouden. Voor het berekenen van het aantal uren zijn we uitgegaan van een looptijd van de pilot van 20 maanden ( 80 weken).

\subsubsection{Tijdsbesteding uitvoering werkproces}

De tijdsbesteding betreft ureninzet voor de detectie en monitoring van potentiële combi-zaken, de voorbereiding en uitwerking van de (zaken op de) huiselijk geweldzitting en de zittingsduur. Er is van tevoren niet bepaald tegen welke tijdsbesteding dit wordt afgewogen. 


\section{Detectie en monitoring van zaken}

Sinds de start van de huiselijk geweldzittingen binnen de pilot hebben de dossiercoördinatoren van de rechtbank Rotterdam tijd besteed aan de uitvoering van de detectie, monitoring en planning van de zaken. Het gaat om tijd die wordt besteed aan potentiële combi-zaken en tijd voor geagendeerde zaken op de huiselijk geweldzitting die niet tot een combi-zaak leiden. Het gaat om circa 12 uur per week, over een looptijd van zestien maanden (september 2018 tot januari 2020). In totaal gaat het om 768 uur. Dit heeft 28 combi-zaken opgeleverd (zie tabel 3.3).

Voor de monitoring van potentiële combi-zaken die door een medewerker van het ZVHRR wordt uitgevoerd, wordt acht uur per week gereserveerd. Hiertoe is zoals eerder gezegd in februari 2020 beslist en in april 2020 is men gestart met de uitvoering. Het is dus nog niet duidelijk wat de werkelijke tijdsbesteding op langere termijn is en hoeveel zaken dit gaat opleveren.

Tabel 3.3 Totale tijdbesteding rechtbank tussen september 2018 en januari 2020 en van ZVHRR vanaf eind januari 2020 voor detectie en monitoring potentiële combi-zaken

\begin{tabular}{llll}
\hline & $\begin{array}{l}\text { Totaal aantal } \\
\text { uren }\end{array}$ & $\begin{array}{l}\text { Gemiddeld } \\
\text { aantal uren per } \\
\text { maand }\end{array}$ & $\begin{array}{l}\text { Gemiddeld } \\
\text { aantal uren } \\
\text { per week }\end{array}$ \\
\hline $\begin{array}{l}\text { Dossiercoördinator } \\
\text { Rechtbank }\end{array}$ & 768 & 192 & 12 \\
\hline $\begin{array}{l}\text { Tijdsbesteding ZVHRR } \\
\text { voor monitoring (vanaf } \\
\text { eind januari 2020) }\end{array}$ & - & - & 8 \\
\hline
\end{tabular}

\section{Voorbereiding, uitwerking en zittingsduur combi-zittingen}

Door de rechtbank is gekeken naar het aantal uren dat een rechter en juridische ondersteuner nodig hebben voor de voorbereiding, behandeling van zaken en uitwerking van een combi-zaak op de huiselijk geweldzitting. Zoals eerder gezegd worden op de huiselijk geweldzitting ook zaken behandeld waarvan men vermoedt dat er sprake is van overige (civielrechtelijke) problematiek in het gezin en zaken waarin het uiteindelijk niet lukt om de strafzaak te combineren met een civiele zaak. Er is daarom een uitsplitsing gemaakt tussen huiselijk geweldzittingen zonder combizaken en huiselijk geweldzitting met een combi-zaak. In totaal kon van 26 huiselijk geweldzittingen de tijdsbesteding inzichtelijk gemaakt worden, waarvan 18 huiselijk geweldzittingen zonder combi-zaak en acht zittingen met combi-zaak. Tijdens vier van die acht zittingen zijn twee combi-zaken behandeld en bij vier zittingen één combizaak (zie tabel 3.4). De tijdsbesteding is per zitting en niet van alle zaken. We hebben 
de tijdsbesteding per zitting gedeeld door het aantal behandelde zaken op de zitting om een gemiddelde tijdsbesteding te berekenen.

Tabel 3.4 Gemiddeld aantal bestede uren per huiselijk geweldzaak tussen oktober 2018 en januari 2020

\begin{tabular}{llll}
\hline & $\begin{array}{l}\text { Huiselijk } \\
\text { geweldzitting met } \\
\text { een combi-zaak } \\
(\mathrm{n}=4)\end{array}$ & $\begin{array}{l}\text { Huiselijk } \\
\text { geweldzitting met } \\
\text { twee combi-zaken } \\
(\mathrm{n}=4)\end{array}$ & $\begin{array}{l}\text { Huiselijk } \\
\text { geweldzittingen } \\
\text { zonder }\end{array}$ \\
\hline $\begin{array}{l}\text { combi-zaak (n=18) } \\
\begin{array}{l}\text { Voorbereidings- en } \\
\text { uitwerkingstijd } \\
\text { rechter }\end{array}\end{array}$ & $2 \mathrm{u}$ & $1,2 \mathrm{u}$ & $1 \mathrm{u}$ \\
$\begin{array}{l}\text { Voorbereidings- en } \\
\text { uitwerkingstijd } \\
\text { juridisch } \\
\text { ondersteuner }\end{array}$ & $3,5 \mathrm{u}$ & $3,5 \mathrm{u}$ & 2,3 \\
$\begin{array}{l}\text { Zittingstijd per } \\
\text { zaak }\end{array}$ & 0,8 & & 0,7 \\
\hline
\end{tabular}

Bron: registratiegegevens pilot HG-rechtbank Rotterdam

\section{Meer tijd kwijt aan de voorbereiding en uitwerking}

Het voorbereiden en uitwerken van combi-zaken kost meer tijd dan zaken waarin de strafzaak niet gecombineerd wordt met een civiele zaak (zie tabel 3.4). Dit is volgens verwachting; er moeten immers twee zaken worden voorbereid. Wat betreft huiselijk geweldzittingen in de pilot waar geen combi-zaak wordt behandeld en politierechtezittingen waar huiselijk geweldzaken worden behandeld, vermoeden rechters dat er nauwelijks verschil is in voorbereidings- en uitwerkingstijd. Er is echter geen analyse van de voorbereidings- en uitwerkingstijd van politierechterzittingen gedaan, om het vermoeden van de rechters te toetsen.

\section{Zittingstijd}

Bij de planning van de huiselijk geweldzitting wordt uitgegaan van één uur voor combi-zaken en een half uur voor zaken waarbij de strafzaak niet gecombineerd wordt met een civiele zaak. Op basis van de cijfers van de 18 zittingen waar geen combizaak is behandeld, stellen we een gemiddelde zittingsduur van drie kwartier vast. En van 28 zaken (geen combi-zaken) op die 18 zittingen is specifiek de tijdbesteding per zaak bijgehouden. Hieruit komt een gemiddelde duur van 36 minuten per zaak, met 
een minimum van 6 minuten en een maximum van 75 minuten. De gemiddelde tijdsbesteding is meer dan de geplande 30 minuten. Van zes combi-zaken is de zittingsduur geregistreerd. Gemiddeld duurde de behandeling van een combi-zaak 75 minuten, met een minimum van 30 minuten en een maximum van 105 minuten.

De zittingsduur betreft dus de tijd voor de strafzaak en een of meerdere civiele zaken.

We concluderen dat in de pilot organisatorische en logistieke aanpassingen zijn doorgevoerd in de reguliere werkwijze voor de strafrechtelijke behandeling van huiselijk geweldzaken om de beoogde doelen in de pilot te bereiken. De meeste aanpassingen richten zich op het eerder en meer informatie beschikbaar hebben voor de afweging of een huiselijk geweldzaak een potentiële combi-zaak is en in aanmerking komt voor de speciale huiselijk geweldzitting. De detectie van potentiële combi-zaak bleek lastig. Veel aanpassingen gedurende de looptijd van de pilot zijn genomen omdat het aantal combi-zaken achterbleef op de verwachte twee zaken per week. Daarnaast zijn organisatorische aanpassingen doorgevoerd voor het sneller en integraal behandelen van combi-zaken. Aangemelde potentiële combi-zaken worden na aanmelding binnen drie maanden geagendeerd op de speciale huiselijk geweldzitting. Op deze zitting is meer tijd gepland voor combi-zaken en voor huiselijk geweldzaken die niet gecombineerd worden. Er is een vaste poule van vijf rechters, twee dossiercoördinatoren en een vaste poule van vijf juridische ondersteuners.

De monitoring van potentiële combi-zaken en huiselijk geweldzaken die worden aangemeld voor de huiselijk geweldzitting is een aandachtspunt gebleken. Het is nog onduidelijk of het werkproces zoals het aan het eind van het onderzoek is vormgegeven een passende oplossing biedt. Het bleek voor de betrokken organisaties zoeken om te bepalen op welk moment in het werkproces, en daarmee door welke organisatie, monitoring moet gebeuren en wat precies gemonitord ging worden. Uiteindelijk is besloten tot twee monitoringsmomenten (bij ZVHRR en de rechtbank). Of de manier waarop de monitoring momenteel is vormgegeven bij het ZVHRR goed werkbaar is en bijdraagt aan de detectie en monitoring van huiselijk geweldzaken (zonder civiele zaak) en potentiële combi-zaken, is nog de vraag.

Bovendien vraagt de monitoring om een forse tijdsinvestering in relatie tot het aantal combi-zaken dat uiteindelijk tot stand komt.

Een ander aandachtspunt blijkt de informatie-uitwisseling tussen VT en RN. Dit blijkt echter een landelijke kwestie te zijn, waar in de pilot tegenaan werd gelopen. Een oplossing in geval van voortzetting van de werkwijze zou kunnen zijn om de informatiedeling niet via RN, maar via bijvoorbeeld het OM of RvdK te laten lopen waar al duidelijke afspraken mee zijn.

Tot slot is SHN te weinig meegenomen in de voorlichting over het doel en opzet van de pilot. 


\section{Effectevaluatie}

De effectevaluatie geeft antwoord op de vraag:

In hoeverre slaagt de pilot erin om de effecten te realiseren die met de pilot zijn beoogd?

In dit hoofdstuk presenteren we de resultaten van de vier doelen van de pilot (zie figuur 4.1 voor schematische weergave):

\section{Samenwerking}

Meer samenwerking tussen de ketenpartners in de vorm van extra en eerdere informatie-uitwisseling. Dit is een voorwaarde voor een snellere en integrale behandeling van huiselijk geweldzaken.

\section{Snelheid}

Een snellere behandeling van huiselijk geweldzaken (dat wil zeggen het sneller op zitting brengen van de strafzaken).

3. Integraliteit

Het integraal behandelen van strafrechtelijke en andere lopende juridische procedures - uit familie- en jeugdrecht - in het gezin op de huiselijke geweld zitting.

4. Kwaliteit

De rechterlijke interventies uit de strafrechtzaak en de civiele zaak zijn op elkaar afgestemd en op de problematiek van het gezin. 


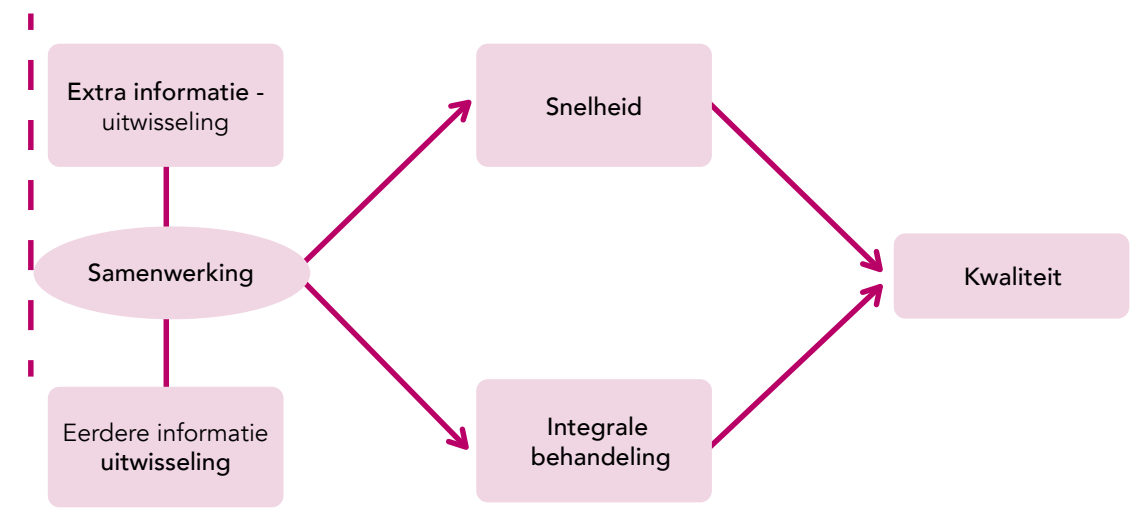

Figuur 4.1. Beoogde effecten van de pilot geïntegreerde aanpak huiselijk geweld.

\subsection{Samenwerking}

\subsubsection{Extra informatie-uitwisseling}

Extra informatie-uitwisseling heeft betrekking op het verkrijgen van meer informatie over de verdachte, zijn/haar gezin en de problemen die er spelen. Die extra informatie moet enerzijds helpen bij het beoordelen van de mogelijkheid om de strafzaak met een civiele zaak te combineren. Anderzijds moet die extra informatie tijdens de huiselijk geweldzitting binnen de pilot de rechter helpen om een beeld te krijgen van de problematiek die aan het huiselijk geweld ten grondslag ligt om zo tot een passende interventie te komen.

Wij maken onderscheid in twee fasen waarin extra informatie-uitwisseling wordt gerealiseerd:

1. Op ZSM/Veiligheidshuis: voor de detectie van potentiële combi-zaken

2. Op de rechtbank Rotterdam: voor de behandeling van de combi-zaak

\section{Extra informatie voor detectie van potentiële combi-zaken}

In het begin van de pilot hadden de ketenpartners van ZSM/Veiligheidshuis weinig tot geen informatie bij het bespreken van de huiselijk geweldzaken over eventuele kinderen die betrokken waren, en of er een echtscheiding liep. Dit bleek al tijdens de voormeting die door ZVHRR is uitgevoerd. Om meer informatie over eventuele civiele zaken en de betrokkenheid van kinderen te achterhalen, is gedurende de pilot besloten het sjabloon voor de aangifte en het sociaal verhoor van de politie aan te passen, zodat 
agenten standaard bij de aangifte en het sociaal verhoor daarnaar vragen. Zoals in paragraaf 3.3 al aan bod kwam, blijkt deze afspraak niet te hebben geresulteerd in de daadwerkelijke aanpassing van het sjabloon voor de aangifte en het sociaal verhoor, of een verandering van het protocol voor politiemensen. Het bleek niet haalbaar om de geautomatiseerde systemen waarmee voor de aangifte en bij een verhoor wordt gewerkt, aan te passen.

Ondanks dat bovengenoemde afspraak niet haalbaar bleek, heeft de portefeuillehouder huiselijk geweld bij de politie wel de doelgroepencoördinatoren in de districten gewezen op het belang van het sociaal verhoor in relatie tot deze pilot. Dit heeft er in geresulteerd dat gaandeweg de pilot vaker informatie over echtscheidingsproblematiek en problemen met de omgang met kinderen in de processen-verbaal is opgenomen. Het is van de agent afhankelijk of hij dit opneemt. Deze informatie is van belang omdat het een beeld schetst van hoe de verdachte tegenover zijn/haar partner (slachtoffer) en hun relatie staat. Dit beeld kan helpen bij de detectie van potentiële combi-zaken. Zo kan uit het proces-verbaal blijken dat de verdachte en het slachtoffer hun relatie willen continueren of juist willen beëindigen. In het laatste geval brengt dit bij de officier van justitie op ZSM de vraag omhoog of ze zelf tot afspraken willen komen of dat ze de echtscheiding via de rechter willen regelen. In laatstgenoemde geval is er mogelijk sprake van een potentiële combi-zaak waarna de officier van justitie de verdachte en het slachtoffer kan informeren over de mogelijkheden van een combi-zitting.

Naast de extra informatie die wordt verzameld door de politie, wordt door een medewerker van het ATP standaard informatie opgevraagd bij de RvdK over de aanwezigheid van kinderen in het gezin en de gezinssituatie. En zoals gebruikelijk wordt informatie van VT, RN en Jeugdbescherming op het ATP verzameld.

We concluderen dat het beoogde effect om meer informatie beschikbaar te hebben voor detectie van potentiële combi-zaken deels is bereikt.

\section{Extra informatie voor behandeling combi-zaak}

Rechters en juridische ondersteuners hebben naar eigen zeggen meer informatie op zitting dan tijdens een reguliere politierechterzitting. Waar zij tijdens een politierechterzitting alleen beschikking hebben over het proces-verbaal van de politie en in sommige gevallen een slachtofferverklaring en/of adviesrapport van RN, is voor alle zaken die op de huiselijk geweldzitting gepland staan een adviesrapport van RN beschikbaar. In de eerste ronde interviews in oktober 2019 meldden geïnterviewde rechters dat adviesrapportages nog regelmatig tijdens de huiselijke geweldzittingen in de pilot ontbraken. In januari 2020 gaf de respondent van RN echter aan geen signalen meer te krijgen dat adviesrapportages ontbreken. De rechters beaamden dit in de eerste reflectiebijeenkomst in januari 2020. Ook bleek tijdens de eerste 
reflectiebijeenkomst met de ketenpartners dat in steeds meer adviesrapportages informatie van VT is opgenomen. Door deze adviesrapportages en de eventuele daarin opgenomen informatie van VT, krijgen rechters inzicht in de gezinssituatie van verdachten.

De extra informatie geeft rechters en juridische ondersteuners een beter beeld van de problemen die aan het huiselijk geweld ten grondslag liggen. Bovendien hebben rechters naar eigen zeggen beter zicht op welke hulpverlening al op touw is gezet. De extra informatie wordt door rechters gebruikt om een dialoog met de verdachte en het slachtoffer aan te gaan en nog meer informatie over de problematiek in het gezin te verzamelen, zo blijkt uit de interviews met de rechters. Dit in tegenstelling tot een politierechterzitting waar rechters gericht zijn op het verzamelen van alleen de benodigde informatie om de strafzaak af te doen. In paragraaf 4.3 gaan wij hier verder op in.

Zittingsvertegenwoordigers van de RvdK die bij combi-zittingen aanwezig zijn geweest, hebben, volgens een respondent van de RvdK, ook meer informatie dan tijdens een reguliere familie- of jeugdrechtzitting. Zij krijgen informatie uit het adviesrapport van RN te horen waar zij anders niet over beschikken. Volgens de respondent kan die extra informatie van invloed zijn op het advies dat de RvdK geeft in de civiele zaak.

De respondent noemde het volgende voorbeeld:

"In een combi-zaak stond een vader terecht voor huiselijk geweld. Uit het adviesrapport van de reclassering bleek dat hij eerder niet aan een behandeling voor zijn agressie wilde meewerken. De reclassering adviseerde daarom verplichte deelname aan een behandeling. Uiteindelijk adviseerde de zittingsvertegenwoordiger, mede op basis van het advies van de reclassering, begeleide omgang in plaats van onbegeleide omgang." (respondent RvdK)

Daarnaast geeft de respondent van VT aan dat de contextinformatie die VT geeft in een strafzaak invloed heeft op de afdoening van de strafzaak. Vervolgens kan in de beslissing van de strafzaak, door die contextinformatie, rekening worden gehouden met de veiligheidsmaatregelen die VT in het (vrijwillig) civiele kader uitvoert. Zodoende is ook VT gebaat bij en voorstander van een integrale behandeling, omdat de beslissing uit de strafzaak op de veiligheidsmaatregelen in het civiele kader aansluit.

We concluderen dat het beoogde effect om meer informatie ter beschikking te hebben voor de behandeling van de zaak op de huiselijk geweldzitting is behaald. 


\subsubsection{Eerdere informatie-uitwisseling}

Ook eerdere informatie-uitwisseling heeft betrekking op twee fasen van het proces in aanloop naar de combi-zitting:

- Eerdere informatie-uitwisseling ten behoeve van de beslissing of een huiselijk geweldzaak die in aanmerking komt voor een combi-zitting.

- Eerdere informatie-uitwisseling zodat tijdens de combi-zitting altijd een adviesrapport van RN beschikbaar is, en indien van toepassing, het rapport van het onderzoek door de RvdK.

\section{Eerdere informatie-uitwisseling voor de detectie}

Zoals eerder genoemd wordt gedurende de looptijd van de pilot meer informatie over de problematiek en de betrokkenheid van kinderen opgenomen in het proces verbaal. Hierdoor kan de officier van justitie op ZSM met name in de weekenden sneller komen tot een afdoeningsbeslissing. In de weekenden zijn niet alle ketenpartners op ZSM aanwezig om navraag te doen over de gezinssituatie, wat zou betekenen dat in het reguliere werkproces de afdoeningsbeslissing na het weekend kan worden genomen.

\section{Eerdere informatie-uitwisseling voor behandeling combi-zaak}

Tussen RN en ZVHRR is een verkorte aanlevertermijn voor adviesrapportages afgesproken (acht weken i.p.v. tien weken). Zoals in paragraaf 3.3 aan bod kwam, is deze afspraak met RN niet door het OM bestendigd en is de verkorte termijn niet voor alle zaken op de combi-zitting haalbaar gebleken. Dit resulteert erin dat adviesrapportages over het algemeen binnen de gebruikelijke tien weken beschikbaar zijn, waarbij het in sommige gevallen lukt om de verkorte termijn van acht weken te halen. Complexiteit van de casus is bepalend voor de aanlevertermijn, alsmede de afspraken die over de aanlevertermijn met de officier van justitie worden gemaakt. Dat de verkorte termijn niet altijd haalbaar is, lijkt geen bezwaar te zijn voor het $\mathrm{OM}$ en de rechtbank Rotterdam. Het is bovenal van belang dat het adviesrapport beschikbaar is voor de zitting, zo blijkt uit de eerste reflectiebijeenkomst.

Gedurende de pilot is met de RvdK de afspraak gemaakt dat voor potentiële combi-zaken door de RvdK wordt nagegaan of een verzoek voor een raadsonderzoek is ingediend of mogelijk wordt ingediend. Als dat het geval is, worden die zaken eerder 'uitgedeeld' (dat wil zeggen eerder uitgevoerd). Op deze manier tracht de RvdK de lange wachtlijsten voor raadsonderzoek te omzeilen zodat voorkomen kan worden dat er geen raadsonderzoek voor de behandeling van het jeugdrechtelijke deel tijdens de combi-zitting beschikbaar is. Deze wijziging is in oktober 2019 doorgevoerd, wat het te vroeg maakt om uitspraken te doen over de uitvoeringspraktijk van deze wijziging. 
We concluderen dat het beoogde effect om eerder informatie beschikbaar te hebben deels is bereikt.

\subsection{Snelheid}

In de pilot worden de potentiële combi-zaken drie maanden na aanmelding geagendeerd op de huiselijk geweldzitting. De doorlooptijden van 18 combi-zaken tussen september 2018 en augustus 2019 waren beschikbaar voor de analyse van de doorlooptijden. Deze hebben we vergeleken met de doorlooptijden van 14 mogelijke combi-zaken uit de voormeting (zie tabel 4.1). Hierbij moet de kanttekening worden geplaatst dat van de 18 combi-zaken de pleegdatum is genomen, en bij de 14 zaken uit de voormeting de datum van aangifte.

De gemiddelde doorlooptijd tussen de pleegdatum en de datum van uitspraak voor zaken behandeld in de pilot is korter (vijf maanden versus negen maanden) dan zaken behandeld door de politierechter. Het aantal zaken is beperkt. Bij een beperkt aantal casussen is een groter verschil nodig om een statistisch significant verschil te bereiken. Ondanks dat het aantal zaken te beperkt is om statistisch te toetsen, concluderen we dat er een duidelijke trend zichtbaar is dat in zaken sneller uitspraak wordt gedaan en dat het doel deels bereikt is.

Tabel 4.1 Doorlooptijden van mogelijke combi-zaken in de voormeting $(n=14)$ en combi-zaken tijdens de pilot $(n=18)$ september 2018-augustus 2019

\begin{tabular}{lll}
\hline Doorlooptijd & Voormeting $(n=14)$ & Combi-zaken pilot $(n=18)$ \\
\hline Gemiddelde & 9 maanden & 5 maanden \\
SD & 6,6 & 2,7 \\
Min-max & $2,25-22,5$ & $1,25-12$ \\
Mediaan & 6 maanden & 4 maanden \\
\hline
\end{tabular}

\subsection{Integrale behandeling}

\subsubsection{Het aantal combi-zaken}

Het doel van de pilot was om de huiselijk geweldstrafzaken te combineren met gelijktijdig lopende civiele zaken in het gezin. Op basis van de voormeting was de verwachting dan ongeveer twee strafzaken per week te combineren zouden zijn met een civiele zaak. 
In figuur 4.2 zijn het totaal aantal huiselijk geweldzaken en het aantal combi-zaken op de huiselijk geweldzitting weergegeven. Gemiddeld zijn er per kwartaal ${ }^{29} 55$ huiselijk geweldzaken op de huiselijk geweldzitting van de pilot ${ }^{30}$ behandeld, waarvan gemiddeld vijf combi-zaken. Dit komt neer op gemiddeld vier tot vijf huiselijk geweldzaken en minder dan één combi-zaak per huiselijk geweldzitting. In totaal zijn in de periode van september 2018 tot maart 202028 combi-zaken op de huiselijk geweldzitting behandeld. Over de gehele periode genomen kon $9 \%$ van alle zaken op de huiselijk geweldzitting daadwerkelijk gecombineerd worden met een civiele zaak. In de voormeting werd uitgegaan van een combinatie met $15 \%$.

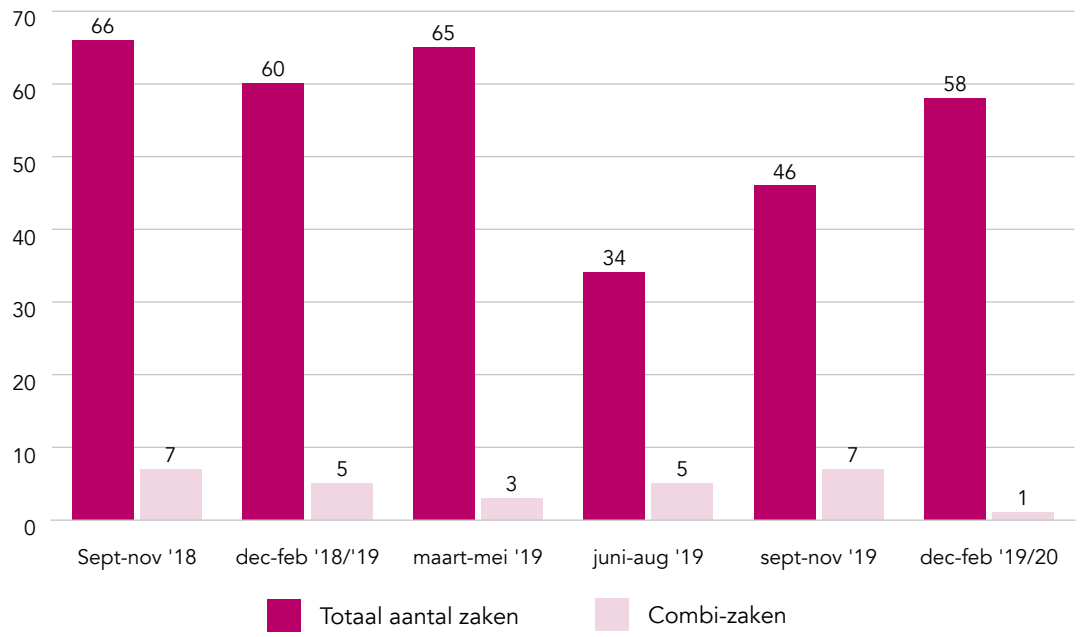

Figuur 4.2. Totaalaantal zaken en combi-zaken op huiselijk geweldzittingen, per kwartaal (2018-2020)

30 In het begin van de pilot werden op de huiselijk geweldzitting ook, bij gebrek aan combi-zaken, de zitting 'opgevuld' met andere strafzaken die die soms niet huiselijk geweld-gerelateerd waren. Het is op basis van de data niet mogelijk om die uitsplitsing te maken. Het uitgangspunt is echter dat alleen huiselijk geweldzaken op de huiselijk geweldzitting worden gepland. Zodoende wordt voor de leesbaarheid hier gesproken over huiselijk geweldzaken. 
Als wordt gekeken naar de verhouding tussen het aantal huiselijk geweldzittingen en het aantal combi-zaken per zitting, zien we dat over de gehele periode minder dan één zaak per huiselijk geweldzitting een combi-zaak betrof (zie figuur 4.3). Dit is aanzienlijk minder dan de twee combi-zaken per combi-zitting die aanvankelijk werden verwacht.

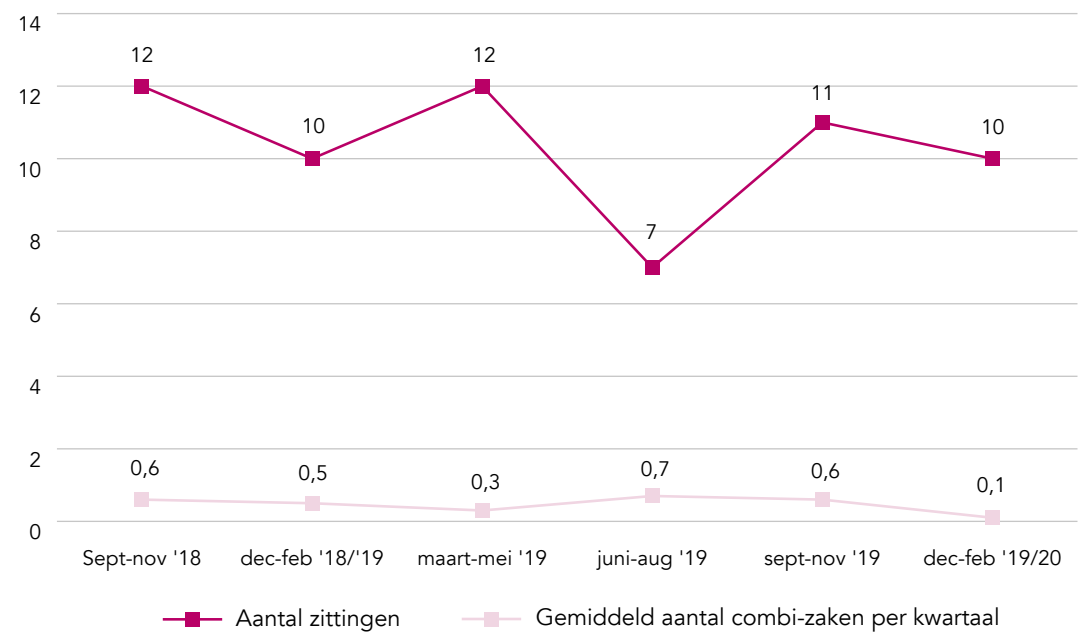

Figuur 4.3 Aantal combi-zittingen en combi-zaken per combi-zitting, per kwartaal (2018-2020)

In totaal zijn er tussen september 2018 en februari 2020137 potentiële combi-zaken gedetecteerd, waarvan 28 combi-zaken doorgingen. In 76 gevallen bleek er geen civiel verzoek te zijn ingediend, in zeven gevallen gaf het slachtoffer geen toestemming en in nog eens zeven gevallen gaf de verdachte geen toestemming. In negentien gevallen werd het geen combi-zaak om diverse redenen (zoals termijnen die niet gelijk liepen).

Op basis van de interviews met respondenten van ZSM/ZVHRR en de rechtbank, en de enquête onder advocaten zijn er grofweg drie redenen die maken dat het aantal combi-zaken lager is dan op basis van de voormeting werd verwacht:

1. Praktische problemen

2. Geen toestemming van verdachte en/of slachtoffer

3. Geen civiele procedure 
Wat betreft de eerste reden, praktische problemen, komt het voor dat de termijn waarop een strafzaak op zitting wordt gebracht niet synchroon loopt met de termijnen die gelden bij de civiele procedure. Zoals hierboven genoemd kwam dit voor in ongeveer $12 \%$ van de potentiële combi-zaken. Een respondent van de RvdK gaf aan dat het bijvoorbeeld voorkomt dat er een melding is gemaakt bij VT en dat VT met het gezin een veiligheidsplan opstelt, wat aanvankelijk afdoende lijkt om de huiselijk geweldproblematiek aan te pakken. Als echter blijkt dat het veiligheidsplan niet het gewenste effect oplevert, wordt er een melding gemaakt bij het Jeugdbeschermingsplein. Daar wordt besloten of de RvdK onderzoek gaat doen. In zo'n geval kan het zijn dat de strafzaak inmiddels al is geweest of bijna wordt behandeld, waardoor het voor de RvdK niet meer haalbaar is om het raadsonderzoek op tijd voor de combi-zitting afgerond te hebben.

De tweede reden, het ontbreken van toestemming van verdachte of slachtoffer kwam voor in ongeveer $10 \%$ van de potentiële combi-zaken. Met betrekking tot deze reden vermoeden geïnterviewde rechters en juridische ondersteuners dat sommige strafrechtadvocaten 'koudwatervrees' hebben om hun zaak met een civiele zaak te combineren. Volgens deze rechters en juridische ondersteuners blijven sommige strafrechtadvocaten ervan overtuigd dat in de strafzaak niks gewonnen kan worden met de gecombineerde behandeling van zaken. Zoals ook verder wordt uitgelegd, hebben advocaten soms de zorg dat met een combi-zaak de rechtsgebieden vertroebeld raken en dat de informatie uit de civiele zaak een nadelig effect heeft op de uitkomst van de strafzaak, of andersom: de advocaten van de civiele zaken hebben de zorg dat informatie uit de strafzaak een nadelig effect heeft op de uitkomst van de civiele zaak.

Een andere reden kan zijn dat een slachtoffer uit strategische overwegingen kiest voor een politierechterzitting, omdat het slachtoffer niet gebaat is bij het sneller afdoen van de civiele zaak - de pilotprocedure leidt doorgaans tot snellere afdoening. Als gevolg van achterstanden bij het familieteam van de rechtbank is de reguliere stroom van civiele zaken namelijk langzamer dan een civiele zaak die met de strafzaak meegaat.

Wat precies de redenen voor slachtoffers en verdachten zijn om geen toestemming te geven is voor de rechtbank niet inzichtelijk geworden. Voor de onderzoekers was het niet mogelijk gegeven de beperkte onderzoektijd en middelen om apart onderzoek te verrichten naar de redenen waarom geen toestemming wordt gegeven.

Ten derde was de meeste voorkomende reden dat partijen uiteindelijk geen civiel verzoek indienen, ook al hadden zij aanvankelijk wel het voornemen dit te doen. In ruim de helft van de potentiële combi-zaken was dit het geval. Het kan bijvoorbeeld gebeuren dat het slachtoffer en de verdachte toch besluiten niet te scheiden en met elkaar verder gaan, of dat zij zelf afspraken maken over de omgang van kinderen zonder tussenkomst van een rechter en/of mediator. 
We concluderen dat in de pilot is uitgegaan van een te hoge verwachting van te combineren zaken. Het daadwerkelijk te combineren zaken is eerder één dan twee per week.

\subsubsection{Integrale behandeling is meer dan alleen combineren van zaken}

Het doel van de pilot was dus om de strafzaak te combineren met een civiele zaak. Gedurende de pilot bleek dat integrale behandeling meer is dan alleen maar het combineren van zaken. De rechters hadden de ervaring dat ook bij de behandeling van de niet-combi-zaken op de huiselijk geweldzitting een integrale behandeling mogelijk is. Ook in de strafzaak kan de problematiek van het gezin die zich (nog) niet in een familie dan wel jeugdrechtelijke procedure heeft vertaald in beschouwing worden genomen.

Een rechter gaf het volgende voorbeeld:

"Stel dat er klappen zijn gevallen vanwege problemen met de omgang met de kinderen, maar er loopt nog geen civiele zaak. Dan kan tijdens de huiselijk geweldzitting worden gekeken of het nodig is om ook rondom de omgang afspraken te maken en of partijen daarvoor een advocaat in de arm moeten nemen." (rechter $B$ )

De ervaringen in de pilot met de huiselijk geweldzittingen leiden tot een bredere definitie van integrale behandeling aan het eind van de pilot. We beschrijven eerst de inzichten van de rechters over wat integrale behandeling volgens hen inhoudt.

Integrale behandeling gaat om twee aspecten:

1. Een integrale blik op het huiselijk geweld

2. Het betrekken van informatie over de context van het huiselijk geweld in de behandeling en afdoening van de strafzaak of combi-zaak

\section{Een integrale blik tijdens de huiselijk geweldzitting}

Waar in een politierechterzitting een rechter gericht is op het afdoen van de strafzaak, hebben rechters tijdens huiselijk geweldzittingen binnen de pilot een integrale blik. Uit de interviews met verschillende rechters blijkt dat de integrale blik - zij noemen dit zelf een mindset - bestaat uit het kijken naar het grotere geheel, met als doel te komen tot een gerechtelijke interventie die bijdraagt aan de vermindering van de problematiek die aan het huiselijk geweld ten grondslag ligt. Dit houdt in dat zij proberen de oorzaken van de problemen in kaart te brengen door informatie te verkrijgen die nodig is om een compleet beeld van de gezinssituatie te krijgen. 
Daarnaast kijken rechters in de afdoening van de huiselijk geweldzaak verder dan alleen naar de strafrechtelijke afdoening, om zo aan te sluiten bij de problematiek die speelt.

Een rechter zei over de integrale blik het volgende:

"De mindset houdt in dat je als rechter met een bredere blik naar het dossier kijkt. Je probeert een 'kijkje achter de voordeur te nemen' door te kijken naar de oorzaken van de problemen, om vervolgens interventie(s) te kiezen waarmee die problemen worden aangepakt. Het gaat om een meer oplossingsgerichte mindset waarbij de belangen van derden (vaak kinderen) ook in acht worden genomen." (rechter A)

Een andere rechter gaf de volgende omschrijving:

"Rechters die aan de pilot meewerken hebben een bredere kijk op alles wat er speelt en zijn bijvoorbeeld ook kritisch richting het slachtoffer wat betreft zijn/ haar aandeel in het geheel. De rechters zijn meer gericht op het vinden van oplossingen en hebben oog voor de impact van de problemen op iedereen. 'Gewone' politierechters zijn daarentegen meer bezig met zaken afhandelen en hebben daarvoor ook minder tijd." (rechter B)

Een rechter vulde op dit punt aan dat de mindset erop gericht is om 'meer begrip bij de verdachte/ benadeelde partij te kweken voor de andere kant. Het gaat om het stellen van vragen waarmee partijen zelf aan het denken worden gezet en gericht zijn op de verwachtingen voor de toekomst'. Voor het stellen van die vragen helpt het rechters, naar eigen zeggen, dat zij over gespreksvaardigheden beschikken, met name om door te vragen om meer tot de kern van de problematiek en de onderliggende belangen te komen. Een rechter die in het verleden mediator is geweest, vertelde dat die ervaring haar helpt om gespreksvaardigheden te gebruiken om de verdachte en het slachtoffer te stimuleren meer over zichzelf en de gezinssituatie te vertellen.

Er zijn een aantal kenmerken van de huiselijk geweldzittingen binnen de pilot die bijdragen aan het toepassen van de integrale blik.

\section{Aanwezigheid van het slachtoffer}

Wat volgens geïnterviewde rechters, juridische ondersteuners en officieren van justitie helpt om uiteindelijk een beeld van de onderliggende problematiek van het huiselijk geweld te krijgen, is de aanwezigheid van het slachtoffer tijdens de huiselijk 
geweldzitting. Omdat het slachtoffer over het algemeen partij is in de civiele zaak, is hij/zij vaak bij een combi-zaak en dus bij de strafzaak aanwezig. Hierdoor kan de rechter ook het verhaal van het slachtoffer over het huiselijke geweld en de onderliggende problematiek horen, gehoor geven aan het leed dat het slachtoffer is aangedaan en inzicht krijgen in het eventuele aandeel van het slachtoffer in het huiselijke geweld.

In een zaak, waar wij ter observatie bij aanwezig waren, vertelde een meneer dat hij al langere tijd onder grote druk stond vanwege een nieuwe baan, de opvoeding van zijn kinderen en door psychische problemen kwam zijn vrouw niet uit bed. De duw die hij zijn vrouw had gegeven was omdat hij brak onder die druk. De immateriële schade die mevrouw in de vordering claimde was volgens meneer echter het gevolg van langer lopende relatieproblemen en problemen met haar mentale gezondheid.

Een rechter zei hierover het volgende:

"In een strafzaak stond een man terecht omdat hij zijn vrouw had geduwd, die daarbij ongelukkig ten val was gekomen. De problemen in de relatie speelden al langer en er was veel mis in de relatie. Als gevolg van de mishandeling was de dochter van meneer erg bang voor hem geworden. Mevrouw zette het feit dat zij psychisch mishandeld was erg dik aan en kwam met een vordering waarmee zij voor het langdurige leed gecompenseerd wilde worden." (rechter C)

Volgens de betreffende rechter kon de geclaimde schade niet worden teruggeleid naar het incident waarvoor meneer terechtstond en daarop verklaarde de rechter de vordering niet-ontvankelijk.

De rechter zei hierover:

"Als de civiele zaak separaat was behandeld had de aangifte voor mishandeling veel nadruk gekregen en was er veel aandacht uitgegaan naar de 'agressieve' vader. Door de integrale behandeling was het mogelijk om de onderliggende problemen in kaart te brengen en de interventies te richten op het herstellen van de band tussen vader en dochter." (rechter $\mathrm{C}$ )

Door het totaalbeeld dat er ontstaat, waarin ook naar de rol van het slachtoffer wordt gekeken, kunnen rechters naar eigen zeggen de strafzaak beter op waarde schatten.

Naast dat de aanwezigheid van het slachtoffer helpt bij het op waarde schatten van de strafzaak ten opzichte van civiele zaak, voelen slachtoffers zich tijdens de 
behandeling van de combi-zaak op de huiselijk geweldzitting ook nadrukkelijk gehoord door de rechter. Een advocaat schreef hierover in de enquête:

"Door de combi met de familiezaak was er (meer) ruimte voor de aangeefster (in dit geval ex-partner) om een visie te geven." (advocaat C)

Een andere advocaat schreef in de enquête over de ervaring van zijn cliënt:

"Het was mooi dat er eerst door dezelfde rechter was vastgesteld dat er echt iets fout was gegaan van meneer naar mevrouw. Daardoor was er erkenning voor haar positie als slachtoffer, met haar pijn en angsten, en werd haar positie tijdens de bespreking van de echtscheiding meer gelijk aan die van de man." (advocaat D)

\section{Ruimte voor emotie}

Naast het feit dat slachtoffers zich tijdens de behandeling van een combi-zaak erkend voelen in hun positie, hebben verdachten, volgens hun advocaten, ook het gevoel gehoord te worden. Volgens geïnterviewde en geënquêteerde advocaten laten rechters meer dan tijdens een politierechterzitting of civiele zaak ruimte voor de emoties van verdachten en slachtoffers. Een reden is dat rechters, door het completere beeld dat ze hebben van de gezinssituatie en problematiek, zien dat niet alleen de verdachten verwijten te maken zijn. Daarnaast hebben de betrokken rechters ruime zittingservaring wat hen helpt om de behandeling van combi-zaken in goede banen te leiden, begrip te tonen voor de spanningen die een rechtszitting met zich meebrengt en ruimte te laten voor de emoties die bij zowel de verdachte als het slachtoffer spelen. Hier is ook meer tijd voor tijdens een huiselijk geweldzitting dan tijdens een reguliere politierechterzitting. Een advocaat schetste in de enquête het volgende beeld:

"Ook al duurde de zitting lang, de rechter had voor elke verdachte evenveel aandacht, waar nodig compassie en liet ruimte open voor emoties." (advocaat B)

Om het verschil met een reguliere politierechterzitting te illustreren waarin de rechter meer gericht is op de afhandeling van de strafzaak, gaf een advocaat in een interview een voorbeeld uit een politierechterzitting:

"Op de vraag van mijn cliënt of hij bij het begin zou beginnen om wat context te geven, antwoordde de rechter: 'ik wil alleen antwoord of de vraag of jij je vrouw hebt bedreigd, ja of nee'." (advocaat C) 
Zoals in subparagraaf 3.4 .2 benoemd, is de tijd die voor de behandeling van zaken op een huiselijk geweldzitting binnen de pilot beschikbaar is van groot belang. Dit om tijd te kunnen besteden aan, onder andere, de emoties van betrokkenen.

\section{Plaats van de verdachte en het slachtoffer in de zittingszaal}

Ook de plaats in de zittingszaal van de verdachte en het slachtoffer naast hun advocaten is volgens geïnterviewde rechters, juridische ondersteuners en advocaten van belang om het gesprek op zitting op gang te brengen. Waar de verdachte tijdens een politierechterzitting in het verdachtenbankje zit en het slachtoffer op de toeschouwerstribune, zitten zij tijdens een huiselijk geweldzitting binnen de pilot beiden naast hun advocaat aan de tafel. Deze fysiek gelijkwaardige positie bevordert volgens respondenten de totstandkoming van een open dialoog. Het kan volgens een geïnterviewde advocaat voor een verdachte onveilig voelen om alleen in een verdachtenbankje te zitten. Door in de combi-zitting te kiezen voor een gelijkwaardige positie, voelen cliënten zich veiliger waardoor zij ook meer geneigd zijn zich open te stellen, de dialoog aan te gaan en informatie te delen, zo stelde een advocaat in een interview.

\section{Het betrekken van informatie uit verschillende domeinen}

De integrale blik, zoals beschreven in voorgaande subparagraaf (5.3.1), is van belang om alle informatie die nodig is om de voor het juridisch oordeel relevante informatie over de onderliggende problematiek van het huiselijk geweld boven tafel te krijgen. Het is vervolgens aan de rechter, en in mindere mate aan de officier van justitie, om de informatie uit verschillende (juridische) domeinen in de behandeling en afdoening van de combi-zaak (of strafzaak als er geen combi-zaak is) te betrekken om daadwerkelijk tot een integrale behandeling te komen. De onderliggende informatie is van belang voor de beoordeling van de strafzaak en de strafeis: wat is er nodig in dit gezin zodat het veilig wordt en blijft en hoe kan het strafrecht daarbij helpen. Uit de observaties van de combi-zaken ( $n=4$, waarvan 1 zaak alleen de strafzaak) blijkt dat dit ook gebeurt; zowel tijdens de strafzaak als de civiele zaak komt informatie uit het andere domein aan bod. En in de uitspraak weegt de rechter informatie uit de verschillende domeinen mee. Zestien van de 32 geënquêteerde advocaten beamen dat tijdens de combi-zaak waar zij een cliënt bijstonden, er sprake was van een integrale behandeling in de zin dat informatie uit het ene juridische domein werd betrokken bij het andere juridische domein.

Naast de positieve waardering zoals hierboven omschreven, zijn er ook kanttekeningen te plaatsen bij het betrekken van informatie uit het strafrecht bij het civielrecht en vice versa, en dient aan bepaalde randvoorwaarden te worden voldaan. 


\section{Volgorde van behandeling}

Een randvoorwaarde die met name voor officieren van justitie van belang is, zo blijkt uit verschillende interviews, is de volgorde waarin de strafzaak en civiele zaak tijdens een huiselijk geweldzitting worden behandeld. Voor officieren van justitie heeft een integrale behandeling alleen toegevoegde waarde als zij de civiele zaak kunnen betrekken in de strafzaak. Dit betekent dat zij idealiter zien dat zij hun requisitoir na behandeling van de civiele zaak en strafzaak houden, om vervolgens hun strafeis te formuleren.

Het is voorgekomen dat een strafzaak en civiele zaak tijdens een huiselijk geweldzitting als twee afzonderlijke procedures zijn behandeld. Na de strafzaak werd direct uitspraak gedaan, voordat werd verder gegaan met de civiele zaak. Volgens alle geïnterviewde officieren van justitie is de behandeling van de civiele zaak na de strafzaak 'mosterd na de maaltijd'. Geïnterviewde rechters beamen dat het een aantal keer is voorgekomen dat een strafzaak en civiele zaak tijdens een huiselijk geweldzitting niet integraal zijn behandeld, wat betekent dat direct na de strafzaak of civiele zaak uitspraak is gedaan voordat de andere zaak werd behandeld. Een reden om direct uitspraak te doen in de strafzaak en de civiele zaak niet af te wachten is, zo bleek tijdens een geobserveerde huiselijk geweldzitting, de kou uit de lucht te halen voordat met de civiele zaak wordt begonnen. De betreffende rechter hoopte in die combi-zaak op die manier dat er meer bereidheid bij de verdachte en het slachtoffer zou komen om de familiezaak te behandelen.

In een aantal combi-zaken waarin het requisitoir en de strafeis van de officier van justitie na behandeling van beide zaken werden geformuleerd, heeft dit volgens geïnterviewde officieren van justitie geresulteerd in een andere strafeis dan zij aanvankelijk in gedachten hadden. Net als rechters zijn de officieren van justitie die bij de pilot betrokken zijn niet alleen gericht op straffen, maar willen ook zij komen tot een constructieve oplossing voor de problematiek in het gezin. Informatie uit de civiele zaak kan daarbij helpen om tot een 'op maat gemaakte strafeis' te komen. Als voorbeeld gaf een officier van justitie:

"Ik zou op basis van de informatie in de strafzaak een onvoorwaardelijke gevangenisstraf geëist hebben. Op zitting bleek de situatie van de verdachte in zijn voordeel veranderd te zijn. Detentie zou de positieve veranderingen doorkruisen. Uiteindelijk heb ik een voorwaardelijke straf, met verplichte behandeling, geëist. De verdachte en het slachtoffer konden zich in die uitspraak vinden en de verdachte had weer uitzicht op omgang met zijn kinderen." (officier van justitie A) 
In het overgrote deel van de combi-zaken wordt volgens de betrokken rechters pas uitspraak gedaan in beide zaken nadat beide zaken zijn behandeld. Of eerst de strafzaak of eerst de civiele zaak aan bod komt, kan verschillen. Een rechter zei hierover:

"Als een verdachte bekent en weinig mitsen en maren heeft dan begin ik vaak met de strafzaak. Wellicht kan ik dan in de bespreking van de civiele zaak en de beslissing in die zaak hetgeen besproken in de strafzaak 'gebruiken'. Als een verdachte (grotendeels) ontkent of veel mitsen en maren heeft [...] begin ik liever met de civiele zaak." (rechter D)

Het werkt volgens deze rechter beter om ontkennende verdachten en verdachten met veel mitsen en maren niet direct te confronteren met hetgeen zij fout hebben gedaan, maar hun eerst de mogelijkheid te bieden hun verhaal te doen tijdens de behandeling van de civiele zaak. Zo voorkom je dat de verdachte in de verdediging schiet en minder op zichzelf reflecteert, en dat de dialoog die je als rechter probeert te creëren niet (meer) mogelijk is.

\section{Conflicterende belangen van verdachten en slachtoffers in de rechtsgebieden}

Door de integrale behandeling bestaat bij advocaten de zorg dat de belangen die een verdachte of slachtoffer heeft tijdens de strafzaak botsen met de belangen die hij/zij heeft tijdens de civiele zaak. Een geënquêteerde advocaat gaf aan blij te zijn dat de strafzaak van zijn cliënt niet als combi-zaak is behandeld. Een gecombineerde behandeling van het huiselijk geweld met de omgangsregeling had volgens hem mogelijk nadelige gevolgen gehad voor zijn cliënt. Het kan volgens deze advocaat voor verdachten moeilijk te overzien zijn wat de impact is van het delen van informatie tijdens de behandeling van de strafzaak op de civiele zaak en vice versa. Een geïnterviewde advocaat die een cliënt wel in een combi-zaak bijstond, sprak over de vertroebeling van de rechtsgebieden:

"Als de verdachte in het strafdeel informatie deelt die in het civiele deel tegen hem werkt, kan dat betekenen dat de civiele advocaat van de tegenpartij daardoor de rol aanneemt van tweede officier van justitie. Dit geldt ook voor de informatie uit het reclasseringsrapport dat eventueel in het strafdeel ter sprake komt. In enkelvoudige strafzaken komt het slachtoffer vaak niet naar de zitting en is hij of zij ook niet van de informatie uit het reclasseringsrapport op de hoogte. In een combi-zaak horen zowel het slachtoffer/tegenpartij als diens civiele advocaat dergelijke informati,e wat nadelig kan uitwerken op de verdachte in de civiele afhandeling. Er is zodoende sprake van een disbalans. "(advocaat F) 
Een advocaat gaf in de enquête te kennen dat in een combi-zaak de officier van justitie werd gevraagd om zich uit te laten over de ondertoezichtstelling, wat zij vervolgens ook deed. De betreffende advocaat vond dit onnodig omdat daarmee de rol van de officier van justitie niet meer duidelijk was. Ook een officier van justitie zei dat zij zich kan voorstellen dat door een gecombineerde behandeling het voor een verdachte lastig te overzien kan zijn wat de gevolgen zijn van het delen van informatie tijdens de strafzaak op de civiele zaak, en andersom.

Officieren van justitie en advocaten verlangen van de rechter, nog meer dan tijdens een politierechterzitting, een sturende rol om ervoor te zorgen dat een verdachte, maar ook een slachtoffer en de aanwezige advocaten, de combi-zitting goed kunnen volgen en hun rechten gewaarborgd blijven. Uit de verschillende interviews met officieren van justitie en advocaten blijkt dat de rechters die bij de pilot betrokken zijn voldoende een sturende rol aannemen en de specifieke vaardigheden hebben om de huiselijk geweldzitting in goede banen te leiden. Rechters beaamden tijdens een groepsinterview dat verwachtingsmanagement erg belangrijk is. Dat wil zeggen dat zij duidelijk moeten maken aan de verdachte, het slachtoffer en hun advocaten welke informatie tijdens welk deel van de zitting ter sprake kan worden gebracht. Bovendien zijn de formaliteiten die tijdens een strafzaak en civiele zaak gelden ook gewoon in een combi-zaak van kracht. Zo wordt een verdachte in de strafzaak gewezen op zijn of haar zwijgrecht en wordt de civiele zaak achter gesloten deuren behandeld.

\section{Meer tijd voor de behandeling}

Een overkoepelende randvoorwaarde voor een integrale behandeling is voldoende tijd. Volgens alle geïnterviewde rechters is tijd de allesbepalende factor voor een effectieve behandeling van huiselijk geweldzaken. Voor de behandeling van een combi-zaak wordt in beginsel een uur uitgetrokken op de huiselijk geweldzitting, voor alleen een strafzaak een half uur. Die tijd hebben rechters naar eigen zeggen ook nodig om alle informatie die zij nodig hebben om een totaalbeeld te krijgen, te verzamelen en de dialoog met de verdachte en het slachtoffer aan te gaan. Dit blijkt ook uit de gemiddeld duur van de behandeling; in tegenstelling tot een reguliere politierechterzitting van 20 minuten, is de gemiddelde duur van de behandeling van een combi-zaak 75 minuten. ${ }^{31}$ Hierbij merken we op dat in die 75 minuten een strafzaak en een civiele zaak (en soms twee civiele zaken) worden behandeld. Maar ook voor de behandeling van huiselijk geweldzaken (zonder civiele zaak) op de huiselijk geweldzitting heeft de rechter meer tijd: gemiddeld 45 minuten. ${ }^{32}$ Bij de duur van de huiselijk geweldzitting wordt vanuit het perspectief van de verdachte, het slachtoffer en hun advocaten een kanttekening geplaatst. Doordat de zittingen langer duren en zaken gecombineerd worden behandeld, wordt meer informatie besproken. Rechters en juridische ondersteuners gaven tijdens het groepsinterview aan signalen te hebben ontvangen dat sommige verdachten en slachtoffers van een combi-zaak afzien, omdat ze bang zijn dat de zitting te intensief

31 Dit blijkt uit analyse van de gegevens van de rechtbank Rotterdam over de duur van zes combi-zaken, verspreidt over acht combi-zittingen.

32 Dit blijkt uit de analyse van de tijdsduur van 18 combi-zittingen zonder combi-zaken (zie paragraaf 4.3.2). 
is vanwege de hoeveelheid informatie die wordt besproken. Daarentegen kent de combi-zaak het praktische voordeel dat de verdachte en het slachtoffer niet meerdere keren op zitting hoeven te verschijnen en de rechter op de hoogte is van de lopende procedures. Een advocaat schreef in de enquête hierover het volgende:

"Het 'verhaal' van de betrokken mensen komt in $1 x$ boven tafel. Dat biedt voordelen. Het is vaak voor mensen niet te begrijpen dat 'de rechter' geen benul heeft van hetgeen zich in andere zalen/op andere verdiepingen afspeelt, terwijl het gaat om hun bestaan, hun kinderen, hun wereldje." (advocaat A)

Ook een klein aantal advocaten plaatst een kanttekening bij de duur van de zitting van de combi-zaak. Als een advocaat zijn cliënt alleen in de civiele zaak of strafzaak tijdens de huiselijk geweldzitting bijstaat, betekent het dat hij/zij in principe bij de hele zitting aanwezig is. Dit geldt zeker als na behandeling van het deel waarin de advocaat zijn cliënt bijstaat niet direct uitspraak wordt gedaan. En zoals een advocaat in de enquête aangaf, is het ongepast als de advocaat na behandeling van de strafzaak de zaal verlaat als de familiezaak nog verder wordt behandeld. Dat advocaten langer bezig zijn met een huiselijk geweldzitting in geval van een combi-zaak, dan met een politierechterzitting of een civiele zaak betekent daarentegen niet dat zij daar meer vergoeding voor krijgen, zo blijkt uit interviews met advocaten. Dit kan volgens de geïnterviewde een financieel knelpunt zijn voor advocaten om aan de zitting van een combi-zaak deel te nemen.

\subsection{Kwaliteit van de interventies}

De integrale behandeling gaat over hoe de rechter de zaken tijdens de huiselijk geweldzitting behandelt. De uitkomst van die behandeling zijn de uitspraken van de strafzaken en de civiele zaken en de rechtelijke interventies die in de uitspraken zijn opgenomen. Onder kwaliteit van de interventies verstaan we in dit onderzoek: interventies uit de verschillende juridische domeinen sluiten op elkaar aan en op de problematiek van het gezin (de verdachte, het slachtoffer, gezin).

\section{Interventies op elkaar afstemmen}

Bij een combi-zaak is het door de integrale behandeling mogelijk om de uitspraken en de bijbehorende interventies in beide zaken op elkaar aan te laten sluiten, aldus de geïnterviewde rechters. Bij een reguliere behandeling van een strafzaak en een civiele zaak, door twee verschillende rechters, kan het gebeuren dat de uitspraken die in beide zaken worden gedaan, elkaar 'bijten'. Rechters hebben bij een combi-zaak niet alleen beschikking over strafrechtelijke interventies maar ook civielrechtelijke interventies, en kunnen met de beslissing die ze in de ene zaak doen in de andere zaak rekening houden. Een randvoorwaarde is, logischerwijs, dat rechters kennis hebben van beide rechtsgebieden. 
Een rechter noemde als voorbeeld dat als een verdachte in de strafzaak een verplichte behandeling opgelegd krijgt om aan zijn agressieprobleem te werken, en in de civiele zaak een ondertoezichtstelling wordt opgelegd waarbij het gezin begeleid wordt door een gezinsvoogd, dat in zo'n geval een werkstraf achterwege wordt gelaten. Volgens die rechter is de aanpak van de agressieproblematiek het belangrijkst en daar is hulpverlening voor nodig. Een werkstraf zou dan wellicht de positieve ontwikkelingen van de verdachte als gevolg van de hulpverlening doorkruisen.

\section{Minder straffen, meer herstellen}

Over het algemeen zijn geïnterviewde rechters, juridische ondersteuners en officieren van justitie van mening dat in de integrale behandeling meer nadruk ligt op het herstellen van de relaties van betrokkenen en de veiligheid in het gezin en hulpverlening, en minder nadruk op het punitieve aspect. In een interview met een rechter werd het volgende voorbeeld genoemd:

"Een rechter kan iemand straffen voor zijn/haar handelen in een bepaalde situatie. Als die situatie zich blijft voordoen door gedoe over de omgang heeft straffen geen zin. Bij een situatie over de omgang komen vaak basale emoties kijken; het gaat om het wel of niet kunnen zien van jouw kind. Het is effectiever om het probleem, de omgang, aan te pakken dan alleen aandacht te besteden aan het huiselijk geweld." (rechter D)

In zijn afweging om te kiezen voor hulpverlening en/of een straf, kijkt een rechter hoe welwillend de verdachte is om met zijn gezin aan de slag te gaan om de situatie en de onderlinge relaties te verbeteren. Hierover zei dezelfde rechter:

"Als er nog 'muziek' in de relatie zit, zal de rechterlijke interventie eerder gericht zijn op het herstellen van die relatie. Vaak in zaken waarin de verdachte en het slachtoffer met elkaar door moeten, dan wel in een relatie dan wel in de omgang met kinderen, zijn interventies meer gericht op herstel en hulpverlening. Bij ontbreken van die 'muziek' wordt er eerder gekozen voor straffen." (rechter D)

Om hulpverlening in te zetten, is het volgens geïnterviewde rechters van belang dat rechters kennis hebben van de sociale kaart. De sociale kaart bestaat uit alle organisaties die zich bezighouden op het gebied van zorg en welzijn. Naast dat de reclassering in een adviesrapport passend advies geeft, en daarbij ook kijkt naar hulpverlening, is kennis van de sociale kaart bij rechters, naar eigen zeggen, ook van belang om passende hulpverlening in te zetten. Een voorbeeld van een zaak die een 
rechter noemde waarin hulpverlening van groter belang was dan straffen had betrekking op een schizofrene verdachte die geen medicatie slikte en vanuit zijn waan iemand had mishandeld. Een ander voorbeeld dat werd genoemd had betrekking op een verdachte die iemand had mishandeld onder invloed van meerdere verdovende middelen.

Als er straffen worden opgelegd zijn dat volgens rechters vaker voorwaardelijke straffen. Het gaat bijvoorbeeld om voorwaardelijke straffen met reclasseringstoezicht of een verplichte behandeling. Ook worden vaker gedragsaanwijzingen opgelegd, zoals contactverboden.

\section{Vermoedelijk vaker aanhouden}

Rechters hebben de mogelijkheid om een rechtszaak aan te houden. Dit betekent dat niet direct uitspraak wordt gedaan, maar dat de zaak op een later moment weer op zitting wordt behandeld. Geïnterviewde rechters geven aan dat zij vaker strafzaken en civiele zaken aanhouden, dan zij bij een reguliere politierechterzitting of civiele zaak doen. Een reden om een zaak aan te houden kan zijn dat een mediationtraject wordt gestart om afspraken te maken over de omgang met de kinderen. Een rechter kan na afronding van het mediationtraject nagaan of partijen inmiddels afspraken hebben gemaakt en welke eventuele andere interventies nog nodig zijn. Andere redenen voor het aanhouden zijn, bijvoorbeeld, het op touw zetten van hulpverlening waarbij de rechter een vinger aan de pols wil houden en om een onderzoek van de RvdK af te wachten.

Uit de interviews blijkt dat rechters het idee hebben dat het aanhouden van de strafzaken effectief is. Zo blijkt het opzetten van hulpverlening in veel gevallen geslaagd en blijkt als gevolg van de mediation dat partijen tot afspraken komen over de omgang met de kinderen. In het kader van dit onderzoek waren geen cijfers beschikbaar om dit vermoeden te onderbouwen.

Potentiële combi-zaken worden binnen drie maanden na aanmelding op de combizitting geplaatst. Uit tabel 4.2 leiden we af dat bij een derde van de combi-zaken op de combi-zittingen binnen drie maanden een uitspraak is gedaan. Bij ruim de helft wordt tussen vier tot zeven maanden een uitspraak gedaan en bij enkele zaken duurt het langer dan acht maanden. Dit kan betekenen dat de zaak is aangehouden. Het aantal aangehouden zaken is niet systematisch geregistreerd. We kunnen dit dus niet goed onderbouwen met cijfers. 
Tabel 4.2 Doorlooptijden huiselijk geweldzaken op combi-zitting (in percentages)

\begin{tabular}{ll}
\hline Doorlooptijd & Percentage huiselijke geweldzaken \\
\hline 0 t/m 3 maanden & $33 \%(n=6)$ \\
4 t/m 7 maanden & $56 \%(n=10)$ \\
8 maanden of langer & $11 \%(n=2)$ \\
\hline Totaal & $100 \%(n=18)$
\end{tabular}

\section{Bron: registratiegegevens pilot HG Rotterdam}

\section{Ervaring van verdachte en slachtoffer}

Het is niet mogelijk gebleken om verdachten en slachtoffers na een combi-zaak te vragen in hoeverre de ingezette rechterlijke interventies aansluiten bij hun behoeften. Uit de interviews met de advocaten komt naar voren dat voor de cliënten die zij bijstonden, de interventies waren afgestemd op hun behoeften. Volgens de advocaten voelden hun cliënten zich tijdens de combi-zaken gehoord en voelden zij zich betrokken bij het komen tot een gezamenlijke oplossing voor de problemen waarmee zij kampen. Een advocaat die op zitting drie familieleden bijstond die alle drie verdachten waren, schreef hierover in de enquête:

"Mijn cliënten voelden zich nadrukkelijk gehoord en hebben direct afstand gedaan van hoger beroep." (advocaat B)

\subsection{Reflectie van de ketenpartners op de effecten}

Het aantal zaken waarin het daadwerkelijk mogelijk was om de strafzaak te combineren met een civiele zaak is voor verschillende ketenpartners tegengevallen. Zij hadden een hoger aantal verwacht. Ondanks het tegenvallende aantal combizaken, heeft de pilot geïntegreerde aanpak de ketenpartners ook veel opgeleverd. Zo wordt betere samenwerking als één van de positieve resultaten van de pilot genoemd. Doordat de ketenpartners beter weten wat de anderen doen en kunnen betekenen met betrekking tot huiselijk geweld, wordt de integrale behandeling gestimuleerd en is er meer informatie beschikbaar om aan die integrale behandeling vorm te geven.

De pilot heeft inzichtelijk gemaakt wat integrale behandeling inhoudt en dat dit ook mogelijk is zonder dat er sprake is van een combinatie van de strafzaak met een civiele zaak. Het belang van een integrale oplossingsgerichte benadering in huiselijk 
geweldzaken is bevestigd. Naast de betere samenwerking is dit volgens de ketenpartners de grootste opbrengst van de pilot.

Ondanks de positieve resultaten in de pilot zijn de ketenpartners het niet eens over of en hoe de huidige werkwijze kan worden voortgezet. Sommige respondenten vinden dat de huidige werkwijze, mits er structurele financiële middelen worden ingezet, in het reguliere werkproces kan worden opgenomen. Andere respondenten vinden dat het daarvoor nog te vroeg is. Tijdens de reflectiebijeenkomst in maart 2020 zijn meerdere manieren genoemd waarop de pilot kan worden doorontwikkeld.

Om de tijdsinvestering meer in verhouding te brengen met het aantal zaken waarin daadwerkelijk de strafzaak en civiele zaak gecombineerd kunnen worden, is het nodig dat er meer zaken worden gevonden. Hiervoor is een effectieve monitoring nodig van de zaken die als potentiële combi-zaken worden aangemerkt en huiselijk geweldzaken waar (nog) geen civiele zaak speelt maar wel het vermoeden is dat er meer aan de hand is. Hiervoor zijn zoals beschreven in hoofdstuk 3 al stappen gezet. Het is nu nog niet duidelijk of deze werkwijze gaat leiden tot meer combi-zaken. Volgens sommige respondenten moet het effect eerst in een verlengde pilotperiode worden onderzocht alvorens deze werkwijze in het regulier werkproces op te nemen. Maar ook als de werkwijze minder zaken oplevert, is de kwaliteitsverbetering die de integrale behandeling oplevert wat betreft respondenten van het Veiligheidshuis, RvdK, VT en RN de tijdsinvestering meer dan waard. De partners in het Veiligheidshuis verwachten dat het werkproces, als het goed loopt, het Veiligheidshuis niet veel extra tijd zal vragen.

Een andere optie die wordt genoemd, is om de rechter eerder in het proces te betrekken en de regie te laten voeren om die zaken te herkennen waarbij naast huiselijk geweld sprake is van andere gezinsproblematiek. Tijdens een regiezitting inventariseert de rechter wat er in een gezin speelt, welke problemen er zijn, welke hulpverlening nodig is en eventueel al is ingezet, en of er eventueel sprake is van een mogelijke combi-zaak. Een regiezitting kan bijvoorbeeld twee weken na de aangiftedatum worden gehouden. ZSM blijft verantwoordelijk voor de selectie van de huiselijk geweldzaken die doorgaan naar de regiezitting, en het Veiligheidshuis zou de informatieverzameling en het betrekken van relevante ketenpartners als rol behouden. Mogelijk zal de detectie van potentiële combi-zaken efficiënter en effectiever verlopen als de regie bij de rechter wordt gelegd. Hoe een geïntegreerde aanpak met regiezittingen vorm zou moeten krijgen en welke partijen welke rol krijgen, vraagt logischerwijs nog om de nodige uitwerking. Voor de invulling van de regiezitting verwijzen de respondenten naar de pilots van de wijkrechtspraak die nu in Rotterdam lopen. Bij verdere uitwerking van deze werkwijze benadrukken de respondenten het belang om zo snel mogelijk in de procedure advocaten in te zetten die de partijen (verdachte, slachtoffer) kunnen vertegenwoordigen. Na een regiezitting volgt later een inhoudelijke behandeling. 
Tijdens de reflectiebijeenkomst werd duidelijk dat het volgens de meeste ketenpartners nog te vroeg is om de geïntegreerde aanpak huiselijk geweld uit te rollen naar andere arrondissementen. Wel is meegegeven dat bij uitrol naar andere arrondissementen niet één op éen mogelijk is omdat de samenwerking tussen ZSM en het Veiligheidshuis in Rotterdam uniek is en niet de landelijke standaard.

Als ook in andere arrondissementen gekozen wordt voor een integrale behandeling van huiselijk geweldzaken raden de ketenpartners aan dat de rechtbank de aanpak initieert bij andere ketenpartners. Hierdoor kan meer draagvlak worden gecreëerd omdat de rechtbank aanzien heeft en de uiteindelijke integrale behandeling moet uitvoeren.

\subsection{Samenvatting effectevaluatie}

De beoogde doelen van de pilot zijn deels bereikt. De resultaten op de vier doelen van de pilot kunnen als volgt worden samengevat.

\section{Samenwerking}

Het doel van de pilot was om de samenwerking tussen de verschillende ketenpartners te verbeteren zodat eerder informatie-uitwisseling en meer informatie-uitwisseling zou plaatvinden. Vooral de samenwerking tussen het ZVHHR en de rechtbank is vergroot, maar ook tussen de rechtbank en het OM. Binnen het ZVHRR was er al een goede samenwerking tussen de ketenpartners. Door de pilot is de samenwerking met betrekking tot huiselijk geweld nog verder verbeterd. Ketenpartners weten beter van elkaar wie wat doet en kan doen.

Met het werkproces werd beoogd om extra en eerder informatie beschikbaar te hebben voor de detectie van potentiële combi-zaken en de behandeling op de huiselijk geweldzitting. Dit doel is deels behaald. Er is meer informatie beschikbaar in de processen verbaal over de gezinssituatie en eventuele echtscheidingsproblematiek bij ZSM. Ook voor de behandeling van de zaak op de zitting is meer informatie beschikbaar. Zo is er altijd een adviesrapportage van de reclassering beschikbaar, wat normaliter voor de politierechterzitting alleen wordt opgevraagd indien de officier van justitie dat nodig vindt.

Een aandachtspunt - hoewel dit in de loop van de pilot verbeterd is - blijft de beschikbaarheid van informatie van Veilig Thuis voor de zitting.

Niet alleen is er meer informatie beschikbaar voor de zitting, ook de rechter zelf vraagt tijdens de zitting, meer dan tijdens een politierechterzitting, informatie over de achterliggende problematiek aan de verdachte en het slachtoffer. 


\section{Snelheid}

Het doel van de pilot was de strafzaken sneller op zitting te brengen. De zaken die worden aangemeld voor een combi-zitting worden binnen drie maanden op zitting gepland. De gemiddelde doorlooptijden tussen pleegdatum en uitspraak van de zaken op de huiselijk geweldzitting is lager dan in de voormeting (vijf maanden versus negen maanden). Sneller op zitting komen hoeft niet te betekenen dat er sneller uitspraak wordt gedaan. Op combi-zittingen hanteren rechters volgens hun zeggen vaker het aanhouden van zaken als interventie.

\section{Integrale behandeling}

Het aantal zaken waarin daadwerkelijk de strafrechtelijke zaak gecombineerd kan worden met een civiele zaak is lager dan van tevoren bedacht. Belangrijke redenen daarvoor zijn het niet tegelijk lopen van strafrechtelijke en civielrechtelijke procedures, dat slachtoffers en/of verdachten geen toestemming geven voor het combineren van strafrechtelijke en civiele procedures of dat geen civiel verzoek wordt ingediend. Gaandeweg de pilot werd duidelijk dat integrale behandeling van huiselijk geweld meer is dan het combineren van juridische procedures. Integrale behandeling betekent dat er met een integrale probleemoplossende blik naar de context van het strafbaar feit en de problematiek achter het huiselijk geweld wordt gekeken. Dit is ook mogelijk als er geen sprake is van een combi-zaak.

\section{Kwaliteit van de interventies}

De rechters stemmen de interventies uit de verschillende juridische domeinen meer op elkaar en op interventies in het vrijwillig kader af. De nadruk ligt minder op straffen en meer op herstellen van de relaties en de veiligheid in het gezin, en het aanpakken van de onderliggende problematiek. 


\section{Conclusies en aanbevelingen}

In dit hoofdstuk trekken we conclusies en doen we aanbevelingen voor het vervolg van de pilot en de aanpak van huiselijk geweld zaken op basis van de lessen in de pilot.

\subsection{Organisatorische en logistieke voorzieningen voor een geïntegreer- de aanpak van huiselijk geweld}

Op basis van de procesevaluatie trekken we de volgende conclusies over welke organisatorische en logistieke voorzieningen in de pilot zijn getroffen en hoe die in de praktijk hebben uitgepakt.

Om de doelen van de pilot te bereiken is voorzien in aanpassingen in het werkproces zodat:

- zo vroeg mogelijk informatie beschikbaar is om te bepalen of een huiselijk geweldzaak in aanmerking komt voor de huiselijk geweldzitting en een potentiële combi-zaak is;

- deze potentiële combi-zaken binnen drie maanden op een speciale huiselijk geweldzitting worden gepland;

- deze potentiële combi-zaken worden gemonitord op gelijktijdig lopende civiele procedures;

- ketenpartners informatie aanleveren voor de integrale behandeling van de combi-zaken op een speciale huiselijk geweldzitting door een vaste poule van rechters en juridische ondersteuners.

\section{Detecteren en monitoren van potentiële combi-zaken}

Het detecteren van potentiële combi-zaken en het vervolgens monitoren of er daadwerkelijk een civiele procedure tegelijkertijd met de strafzaak behandeld kan worden, bleek lastig, ook als er eerder en extra informatie beschikbaar is. De procedures lopen niet altijd gelijk, verdachten en slachtoffers willen niet altijd 
meewerken aan een integrale behandeling of er wordt - ondanks dat er sprake is van problematiek - toch geen civielrechtelijk verzoek ingediend.

Op basis van een voormeting was de verwachting dat er per week twee combi-zaken behandeld konden worden. Dit aantal werd tijdens de pilotperiode niet bereikt. Om mogelijke combi-zaken te detecteren zijn daarom gedurende de pilot door de projectorganisatie verschillende acties uitgezet. We concluderen dat in elk geval de volgende zaken van belang zijn voor de detectie en monitoring van mogelijke combi-zaken:

- Alle ketenpartners (vanaf aanhouding van de verdachte door de politie tot de zitting) inclusief advocaten, slachtoffers en SHN, moeten goed geïnformeerd zijn over de mogelijkheid van het combineren van de strafzaak met een civiele zaak (zowel familie- als jeugdrecht).

- Op verschillende momenten in het werkproces moet een toets worden uitgevoerd (ATP, ZSM en bij de rechtbank) op mogelijke civiele procedures die gecombineerd kunnen worden met de strafzaak.

- Om procedures meer gelijk te laten lopen en combi-zaken binnen drie maanden te kunnen behandelen, moeten afspraken omtrent het aanleveren van adviesrapportages die door de reclassering en de RvdK worden gemaakt, worden vastgelegd en moeten die afspraken ook worden nagekomen.

\section{Integrale behandeling van combi-zaken tijdens de huiselijk geweldzitting}

Als een combi-zaak behandeld wordt op de huiselijk geweldzitting kunnen we op basis van de procesevaluatie concluderen dat de volgende organisatorische en logistieke voorzieningen van belang zijn voor de integrale behandeling:

- Een vaste pool van rechters met kennis van meerdere rechtsgebieden is een noodzakelijke voorwaarde.

- Vaste juridische ondersteuners met kennis van het strafrecht en de mogelijkheid om laagdrempelig collega's vanuit jeugd- en familierecht te raadplegen.

- Voldoende tijd voor de behandeling van zaken. Bij de combi-zaken spreekt dit voor zich omdat er zowel een straf- als civiele zaak wordt behandeld. Echter, ook als er geen sprake is van een combi-zaak heeft de rechter op de huiselijk geweldzitting meer tijd voor het behandelen van de zaak dan op een politierechterzitting (tenminste 30 minuten en gemiddeld drie kwartier versus 20 minuten).

\subsection{Effecten van de pilot}

In de effectevaluatie is onderzocht of de beoogde effecten (output en outcome) in de pilot zijn gerealiseerd (zie figuur 5.1). De beoogde effecten zijn deels bereikt. 


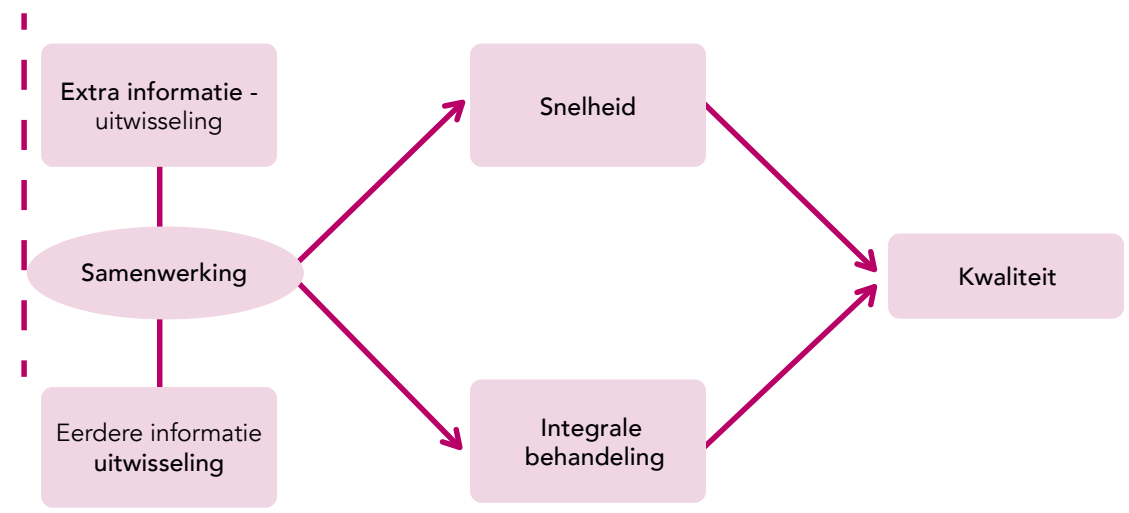

Figuur 5.1. Beoogde effecten van de pilot geïntegreerde aanpak huiselijk geweld.

\section{Samenwerking}

In de pilot is de samenwerking tussen het ZVHHR en de rechtbank vergroot. Voorafgaand aan de pilot was weinig sprake van samenwerking tussen deze twee ketenpartners. Door de pilot hebben zij meer inzicht in elkaars werkprocessen gekregen. Binnen het ZVHRR was er voorafgaand aan de pilot al een goede samenwerking tussen de andere ketenpartners. Een bevorderende factor daarvoor is dat binnen het arrondissement Rotterdam het Veiligheidshuis en ZSM onder één dak zijn ondergebracht. Door de pilot is de samenwerking met betrekking tot huiselijk geweld tussen deze ketenpartners nog verder verbeterd.

Het is in de pilot grotendeels gelukt om eerder informatie beschikbaar te hebben voor de detectie van potentiële combi-zaken en de behandeling op de huiselijk geweldzitting. Er is meer informatie beschikbaar in de processen-verbaal over de gezinssituatie en eventuele echtscheidings- of gezinsproblematiek bij ZSM. Ook voor de behandeling van de zaak op de huiselijk geweldzitting is meer informatie beschikbaar. Zo is er altijd een adviesrapportage van de reclassering beschikbaar, die normaliter voor de politierechterzitting alleen wordt opgevraagd indien de officier van justitie dat nodig vindt. Een aandachtspunt - hoewel dit in de loop van de pilot verbeterd is - blijft het ontbreken van informatie van VT in de adviesrapportages in $\mathrm{RN}$. VT rapporteert niet rechtstreeks aan de rechtbank. Via welke route de informatie van VT het best beschikbaar komt voor de huiselijk geweldzitting, vraagt verdere aandacht. Verder lukt het RN niet in alle gevallen om adviesrapportages binnen de afgesproken verkorte termijn van acht weken aan te leveren. Dit is geen belemmering zo lang de rapportages wel beschikbaar zijn voorafgaand aan de huiselijk 
geweldzitting. Hetzelfde geldt voor de rapportages van de RvdK. Daar lukt het vanwege wachtlijsten niet altijd om de rapportage tijdig aan te leveren, maar hier zijn afspraken over gemaakt om dit knelpunt te verbeteren.

Er is niet alleen meer informatie beschikbaar voor de zitting, ook de rechter zelf vraagt tijdens de zitting meer informatie over de achterliggende problematiek aan de verdachte en het slachtoffer dan in een politierechterzitting.

\section{Snelheid}

Tijdens de pilot zijn alle zaken die worden aangemeld voor de huiselijk geweldzitting binnen drie maanden op zitting gepland. Dit is sneller dan bij reguliere politierechterzittingen. De gemiddelde doorlooptijden tussen pleegdatum en datum van uitspraak van de zaken op de huiselijk geweldzitting is lager dan de politierechterzaken uit de voormeting (vijf maanden versus negen maanden). Het aantal zaken is te beperkt om statistisch te toetsen, maar er is een duidelijke trend dat in zaken sneller uitspraak wordt gedaan. Dit doel is dus bereikt. We maken hierbij wel de kanttekening dat sneller op zitting komen niet hoeft te betekenen dat er sneller uitspraak wordt gedaan. Het komt voor dat de rechters het aanhouden van zaken inzetten als interventie. In de periode tot de volgende zitting kan dan al gestart worden met een aanpak van het huiselijk geweld.

\section{Integrale behandeling}

Tussen september 2018 en maart 2020 zijn 28 combi-zaken behandeld op de huiselijk geweldzitting. Dit is gemiddeld minder dan één combi-zaak per zitting. Op basis van de voormeting was de verwachting twee combi-zaken per zitting. Op basis van deze aantallen is het doel van de pilot niet gehaald. Tijdens de pilot werd echter steeds duidelijker dat integrale behandeling van huiselijk geweldzaken meer is dan alleen het combineren van verschillende juridische procedures. De pilot heeft in kwalitatieve zin inzicht gegeven in wat bij een integrale behandeling van huiselijk geweld komt kijken. Rechters behandelen de huiselijk geweldzaken vanuit het besef dat er bij huiselijk geweld - ook als er geen civiele zaak wordt behandeld - vaak meer aan de hand is dan het incident waarvoor de verdachte terechtstaat. Met dat in gedachten zijn rechters tijdens de huiselijk geweldzitting in de pilot erop gericht niet alleen informatie te verzamelen die ze nodig hebben voor het afdoen van de strafzaak, maar ook op informatie die ze nodig hebben om met de juridische interventies bij te dragen aan een oplossing voor het verminderen van de onderliggende problematiek. Ook op een huiselijk geweldzitting met alleen een strafzaak kan met een meer integrale blik op efficiëntere wijze naar oplossingen voor het conflict of de problematiek worden gekeken. Integrale behandeling van zaken is geschikt voor lichtere huiselijk geweldzaken. Wanneer er sprake is van ernstige huiselijk geweldzaken die door de meervoudige kamer worden behandeld, is het combineren met civiele procedures niet aan te raden omdat een sterkere normstelling in de strafzaak meer nadruk krijgt. 


\section{Conclusies en aanbevelingen}

Bevorderende factoren om dit mogelijk te maken zijn:

- Een oplossingsgerichte integrale blik van de rechter en de officier van justitie op de problematiek achter het huiselijke geweld.

- Gespreksvaardigheden van de rechter waardoor verdachten en slachtoffers gestimuleerd worden hun kant van het verhaal te vertellen.

- Plaatsing van de verdachte in de zittingsruimte naast zijn/haar advocaat in plaats van in het verdachtenbankje en het slachtoffer naast de verdachte, in plaats van op de tribune. Hierdoor ontstaat tot op zekere hoogte gelijkwaardigheid tussen partijen en wordt, met name voor de verdachte, een veiligere omgeving gecreëerd waarin hij/zij eerder geneigd zal zijn informatie te delen. In het onderzoek is overigens niet nagegaan wat dit voor het slachtoffer betekent en wat de verschillende juridische grondslagen van de zaken betekent voor de plaatsing in de zittingsruimte.

- Oog en ruimte voor de emoties die bij huiselijk geweld en de rechtszitting komen kijken, waardoor verdachten en slachtoffers zich meer gehoord voelen dan tijdens een reguliere politierechterzitting.

- De tijd voor de behandeling van de zaak. Tijdens een huiselijk geweldzitting is meer tijd beschikbaar voor een zaak dan tijdens een reguliere politierechterzitting, ook als er geen combi-zaak is. Deze tijd is nodig om alle informatie boven tafel te krijgen, de dialoog met de verdachte en het slachtoffer aan te gaan en uiteindelijk tot een passende beslissing te komen.

Bij de daadwerkelijke combinatie van de strafzaak met een familie- of jeugdzaak is de volgorde waarin de strafzaak en de civiele zaak worden behandeld van belang. De rechters wegen per combi-zaak af in welke volgorde zij de zaken behandelen op basis van de informatie in het dossier. Hiervoor zijn geen eenduidige regels. Dit wordt door de rechter zelf ingeschat. Voor officieren van justitie geldt dat hun voorkeur uitgaat naar het houden van hun requisitoir na behandeling van beide zaken, zodat ook zij in hun strafeis rekening kunnen houden met problemen die in het civiele kader spelen. In sommige zaken doen rechters liever wel direct uitspraak na de strafzaak of civiele zaak als zij daarmee de kou uit de lucht halen. Hoewel het combineren van de juridische procedures vooral als positief wordt gezien, uiten vooral advocaten ook zorgen dat het combineren van procedures nadelig kan zijn voor de verdachte.

\section{Kwaliteit van rechterlijke interventies}

De rechters stemmen de rechtelijke interventies op elkaar af, op interventies in het vrijwillig kader en op de achterliggende problematiek. Verdachten en slachtoffers voelen zich meer gehoord. De rechterlijke interventies zijn naast straffen gericht op het herstellen van de veiligheid in het gezin en hulpverlening. De randvoorwaarde hiervoor is dat rechters kennis hebben van de verschillende rechtsgebieden en de sociale kaart. Bij politierechterzittingen en civiele zaken (zonder strafzaak) komt het voor dat de rechter een uitspraak doet die bijt met eerdere uitspraken die zijn 
gedaan, al dan niet in het andere rechtsgebied. Op basis van de ervaring van de rechters en de advocaten is de kwaliteit van de rechterlijke interventies op de huiselijk geweldzitting goed. In dit onderzoek is echter niet nagegaan welke interventies zijn ingezet en was geen vergelijking mogelijk met interventies van zaken die op de politierechterzitting zijn behandeld. Kwalitatief goede interventies dragen bij aan het op termijn voorkomen van herhaling van het huiselijke geweld. Het nagaan van dit effect viel buiten de scope van dit onderzoek. Om uitspraken te doen over de kwaliteit van de interventies is nader onderzoek nodig.

\subsection{Reflectie van de onderzoekers op de resultaten}

In deze paragraaf reflecteren we op de resultaten van de pilot.

We stellen vast dat het detecteren van potentiële combi-zaken lastig is. Het is niet eenvoudig om in dat werkproces in een vroeg stadium al zicht te hebben op de mogelijke combinatie van de strafzaak met een civiele procedure. De focus lag in de pilot heel sterk op het vinden van (potentiële) combi-zaken. Men wilde het beoogde aantal bereiken. De meeste aanpassingen die men in het werkproces gedurende de pilot heeft doorgevoerd waren gericht op het bevorderen van de detectie van potentiële combi-zaken en het tot stand brengen van combi-zaken. De vraag is echter of de voormeting tot een realistische raming heeft geleid. In de voormeting is geen rekening gehouden met het feit dat verdachten en slachtoffers wellicht niet willen meewerken aan combi-zaken, dat civiele procedures mogelijk niet worden ingediend en dat procedures toch niet qua doorlooptijd te combineren zijn. Er is volgens ons daarom uit gegaan van een te hoge raming van combi-zaken. Het aantal dat daadwerkelijk te combineren is, moet volgens ons naar beneden worden bijgesteld.

Bovendien is een belangrijk inzicht dat integrale behandeling meer is dan alleen maar het combineren van juridische procedures. De focus dient te worden verlegd naar het hogere doel van integrale behandeling van huiselijk geweldzaken, te weten; een zo effectief mogelijke afdoening van huiselijk geweldzaken door de oorzaken van de conflicten bloot te leggen en daar een zo passend mogelijke interventie voor in te zetten, binnen het strafrecht en daarbuiten (civiel of vrijwillig). Als het mogelijk is om de huiselijk geweldzaak te combineren met een civiele zaak is dat mooi, maar daar zou de focus volgens ons niet op moeten liggen. De afspraken die in de pilot zijn gemaakt om meer informatie beschikbaar te hebben voor de huiselijk geweldzitting en de versterkte samenwerking tussen de ketenpartners zijn onzes inziens wel nodig en essentieel om tijdens de strafzaak die integrale en complete focus te leggen. Dat de betrokken samenwerkingspartners van de pilot meer inzicht hebben in wie wat doet en kan doen, zal volgens ons bij het voortzetten van de werkwijze of het aangaan van nieuwe samenwerkingen waardevol zijn. 


\section{Conclusies en aanbevelingen}

Het ultieme doel van deze pilot is op lange termijn maatschappelijke impact te hebben door het voorkomen van escalatie en herhaling van huiselijk geweld. Daarbij zijn samenwerking om de problematiek zo volledig mogelijk in kaart te brengen, snelheid, integraliteit en kwaliteit belangrijk. Het gaat bij het realiseren van dit ultieme doel niet om het zoveel mogelijk realiseren van combi-zaken, maar wel om het hogere doel dat daarmee wordt beoogd, namelijk het via samenwerking, snelheid, integraliteit en kwaliteit efficiënt aanpakken van de problematiek rondom huiselijk geweld.

Bij huiselijk geweld is er veelal sprake van multi-problematiek. De juridische procedures zijn slechts een onderdeel van de aanpak die nodig is om het huiselijke geweld aan te pakken. Een manier om de probleemgerichte aanpak meer vorm te geven, is om de rechter eerder in het werkproces een regierol toe te bedelen. Rechters worden dan eerder in het proces bij een huiselijk geweldzaak (die enkelvoudig kan worden behandeld door de politierechter) betrokken en voeren met de integrale blik dat er mogelijk sprake is van onderliggende problematiek die moet worden aangepakt - de regie over de strafzaak en inventariseren welke problematiek er (nog meer) speelt. Zodoende komt nog eerder de problematiek rondom het huiselijk geweld in kaart. En zo kan bezien worden welke verdere acties of routes nodig zijn voor een effectieve juridische interventie die bijdraagt aan het verminderen van de problematiek achter het huiselijk geweld, zoals de inzet van mediation voor conflicten rondom omgang, gezag en scheiding, de inzet van vrijwillige hulpverlening of gedwongen hulpverlening via een maatregel voor kinderbescherming. Op die manier wordt de problematiek van de verdachte en eventueel het gezin leidend voor het bepalen van de vervolgstappen, in plaats van dat de detectie en totstandbrenging van een combi-zaak het doel is. Dit sluit ook aan bij het uitgangspunt om indien mogelijk eerst hulp in het vrijwillige kader in te zetten. Dit uitgangspunt geldt zowel voor echtscheidings- als jeugdbeschermingsproblematiek. Zo is bijvoorbeeld bekend dat bij echtscheidingsproblematiek civiele zaken ook escalerend kunnen werken in plaats van de-escalerend. De partijen komen meer tegenover elkaar te staan in plaats van dat de dialoog wordt gestimuleerd. Deze aanpak zou in de eerste plaats ontwikkeld moeten worden in huiselijk geweldzaken waar kinderen betrokken zijn. Juist in deze zaken is een integrale aanpak van huiselijk geweld met voldoende oog voor de positie van kinderen van groot belang.

Een belangrijke opbrengst van de pilot is dat duidelijk is geworden dat huiselijk geweld vraagt om specifieke kennis en deskundigheid bij de ketenpartners en de rechters. Zo is het duidelijk dat rechters niet alleen kennis van de verschillende rechtsgebieden nodig hebben maar ook van huiselijk geweld, en tijdens de behandeling op de zitting breder moeten kijken dan naar alleen het delict waarvoor de verdachte terecht staat. Naast specifieke kennis en vaardigheden is het ook nodig dat hiervoor voldoende tijd beschikbaar is op de zitting. Op een politierechterzitting is hier onvoldoende tijd voor. 


\subsection{Lessen en aanbevelingen voor het vervolg}

Hoewel we op basis van de pilot nog niet kunnen concluderen wat het effect is van een integrale behandeling op de gezinnen, zijn we van mening dat de pilot goede aanknopingspunten biedt voor de aanpak van huiselijk geweldzaken. Volgens ons is de vraag over het uitrollen van een geïntegreerde aanpak huiselijk geweld nog niet aan de orde. Beter kan de vraag worden gesteld hoe met gebruikmaking van de lessen uit deze pilot de aanpak verder kan worden doorontwikkeld. Deze lessen zijn ook breder waardevol voor een geïntegreerde aanpak van rechterlijke procedures.

\section{Doorontwikkeling van de integrale benadering}

In de pilot is een goede basis gelegd voor de geïntegreerde aanpak van huiselijk geweldzaken. Het is nu het moment om de aanpak verder door te ontwikkelen en daarbij vooral de focus te leggen op het stoppen en terugdringen van huiselijk geweld, en schade te beperken door te kijken naar de achterliggende problematiek. Het combineren van juridische procedures is daarbij mooi meegenomen maar moet niet het doel zijn. De verdieping van de aanpak moet vooral gezocht worden in het integraal in kaart brengen van de problematiek achter het huiselijk geweld. Zoals in 5.3 benoemd is het aan te raden om de rechter eerder in het proces een regierol toe te bedelen. Hiermee ontwikkelt de aanpak zich richting de huiselijk geweldzitting (domestic violence courts) in andere landen. Bij het verder doorontwikkelen van de pilot is het goed om de doelen tegen het licht te houden en te specificeren. Tevens is het goed om aandacht te besteden aan wat de combinatie van de verschillende rechtsvisies van straf- en civielrecht in de praktijk betekent.

\section{Draagvlak en herhaalde voorlichting}

Uit de pilot blijkt dat een belangrijke randvoorwaarde voor het realiseren van een geïntegreerde aanpak het creëren van draagvlak is. De rechtbank kan hier volgens ons het best het initiatief in nemen. De rechtbank heeft immers een bepaald aanzien en een onafhankelijke opstelling. Herhaalde voorlichting over doel en werkwijze is noodzakelijk om de betrokken ketenpartners goed bij de aanpak te betrekken en te houden.

\section{Specifieke deskundigheid is nodig}

De aanpak vraagt van betrokken ketenpartners een bepaalde mate van deskundigheid. Door te werken met een vaste pool van rechters, juridische ondersteuners en officieren van justitie kan een deskundige pool professionals worden samengesteld. Bij rechters zijn kennis over huiselijk geweld, de verschillende rechtsgebieden en de sociale kaart, ervaring met zittingen en gespreksvaardigheden van belang. Voor de samenstelling van de pool van juridische ondersteuners gaat het juist ook om diversiteit in kennis van rechtsgebieden zodat zij elkaar onderling kunnen aanvullen. Officieren van justitie moeten bereid zijn verder te kijken dan naar alleen 
het strafbare feit. Dit doen ze door oog te hebben voor de problematiek achter het huiselijke geweld en hun strafeis zoveel mogelijk te laten aansluiten op wat nodig is in het kader van de veiligheid en het helpen oplossen van die problematiek. Ook advocaten in huiselijk geweldzaken hebben specifieke deskundigheid nodig en hebben idealiter kennis van meerdere rechtsgebieden.

Privacyregels omtrent het delen van informatie moeten verder worden uitgezocht Het delen van informatie tussen ketenpartners is binnen het strafrechtelijke en civielrechtelijke kader verschillend geregeld. Er is nu nog onvoldoende zicht op wat wel en niet mag en mogelijk is binnen het wettelijke kader van de AVG. Het is aan te raden om dit in een apart onderzoek verder uit te zoeken.

Plaats van de verdachte en het slachtoffer in de zittingsruimte van de rechtbank Bij een combi-zaak zitten de verdachten en slachtoffers tijdens de zitting beiden naast hun advocaat aan tafel. Deze fysieke gelijkwaardige positie bevordert de totstandkoming van een open dialoog. Dit kan volgens ons worden gezien als een best practice en ook op reguliere zittingen in geval van lichte huiselijk geweldzaken worden toegepast, mits dit door het slachtoffer niet als te belastend wordt ervaren. De ervaringen van slachtoffers in het algemeen zijn niet in deze evaluatie aan bod gekomen. Het verdient aanbeveling om in vervolgonderzoek meer inzicht te verkrijgen in de manier waarop slachtoffers de behandeling van een combi-zaak op zitting ervaren.

Tot slot; er is in de pilot door de ketenpartners veel werk verzet dat heeft geleid tot heldere inzichten over de geïntegreerde aanpak van huiselijk geweld. Dit biedt goede aanknopingspunten voor de doorontwikkeling van de aanpak. 


\section{Werkprocessen}

\section{Regulier werkproces huiselijk geweldzaken arrondissement Rotterdam}

Figuur Regulier werkproces behandeling van huiselijk geweldzaak Wanneer een verdachte is opgepakt voor huiselijk geweld wordt de verdachte door de politie verhoord. De informatie uit het inhoudelijke en sociale verhoor wordt samen met informatie van VT, RvdK, RN en Jeugdbescherming op het ATP verzameld, wat in het arrondissement Rotterdam onderdee ${ }^{33}$ is van ZSM/ZVHRR.

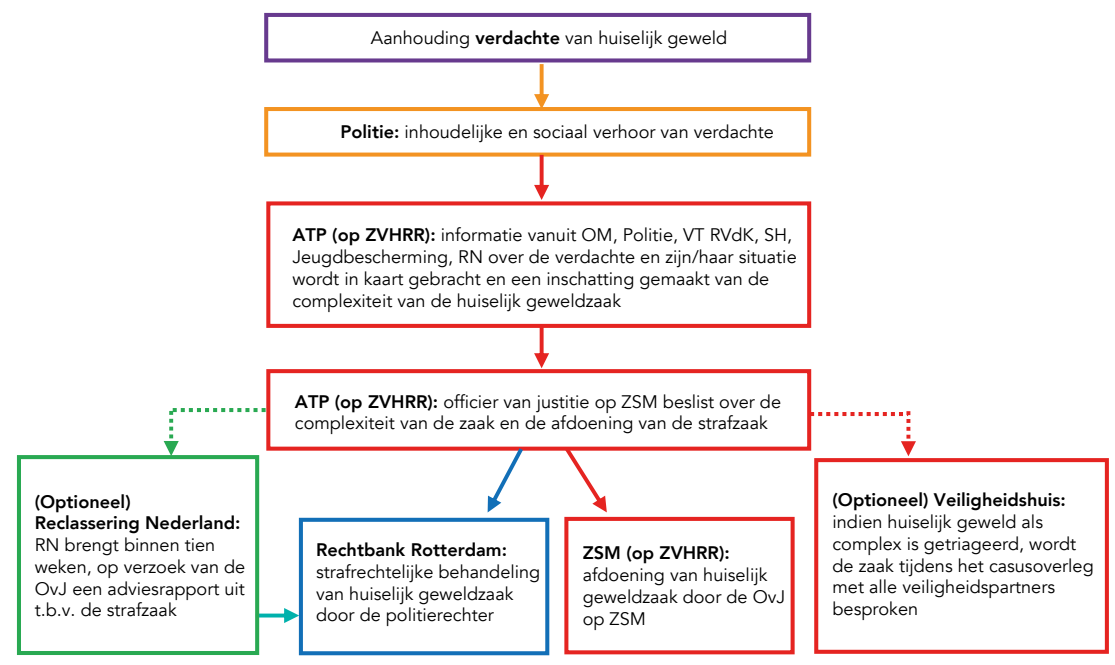

33 Het reguliere werkproces in Rotterdam wijkt af van de rest van Nederland. Kenmerkend aan dat werkproces in Rotterdam is dat, doordat ZSM op dezelfde locatie als het ZVHRR is ondergebracht, er al voor de pilot sprake was van samenwerking en informatie-uitwisseling tussen de verschillende ketenpartners (RvdK, RN, VT, Jeugdbescherming, OM en ZVHRR/ZVHZHZ). 
De ketenpartners van ZSM/ZVHRR maken op basis van die informatie een inschatting van de complexiteit van de casus. Als op basis van de triagecriteria ${ }^{34}$ van het Veiligheidshuis wordt vastgesteld dat er sprake is van een complexe casus, wordt de zaak tijdens het casusoverleg van het Veiligheidshuis besproken. De officier van justitie op ZSM neemt op basis van de informatie die door de ketenpartners is verzameld, een beslissing over de afdoening van de strafzaak. Naast het seponeren van de zaak, kan de officier van justitie kiezen om de strafzaak direct op ZSM of op een OM hoorzitting af te doen of de verdachte te dagvaarden en daarmee de strafzaak door een politierechter of meervoudige kamer te laten behandelen. Indien de officier van justitie dat nodig acht, vraagt hij/zij RN een adviesrapportage over de verdachte op te stellen ten behoeve van de zitting. Complex getriageerde casussen worden daarnaast besproken tijdens het casusoverleg bij het ZVHRR. ${ }^{35}$

\section{Werkproces bij aanvang van de pilot}

Om de doelen van de pilot te bereiken zijn in het reguliere werkproces aanpassingen doorgevoerd. De aanpassingen hebben enerzijds betrekking op het detecteren van potentiële combi-zaken voor de huiselijk geweldzitting in de pilot, en anderzijds op de voorbereiding en behandeling van de zaken op de huiselijk geweldzitting.

34 Er is bij huiselijk geweld sprake van complexe casuïstiek als er na een strafbaar feit sprake is van samenloop van strafrecht en/of bestuursrecht en/of zorg en er problemen zijn op twee of meer leefgebieden en er daarnaast sprake is van één van de onderstaande aanvullende criteria:

1) Het risico op herhaling van huiselijk geweld en/of dreiging geweld is zeer groot en er moet met urgentie een veiligheidsplan worden opgesteld, 2) Er is sprake van een intimite terrorist [d.w.z. een dader van huiselijk geweld waarbij de dader het slachtoffer probeert te domineren door controle en macht uit te oefen, psychisch geweld en dreigen met lichamelijk geweld], 3) Minderjarige kinderen zijn (direct) betrokken als dader, slachtoffer of getuige, 4) Dader of slachtoffer kampen met specifieke persoonsgerichte problemen zoals verslaving, LVB, psychiatrie 5) Er is een huisverbod opgelegd naar aanleiding van een geplande screening vanuit het weegteam bij kindermishandelingszaken, 6) Er is sprake van een potentiële stalkingszaak of van een concrete (ernstige) stalkingszaak, waarbij mogelijk Aware [is een mobiel alarmsysteem] van belang wordt geacht, 7) Er is bij de vraagstelling duidelijk expertise nodig vanuit meerdere ketenpartners."

35 'Er is bij huiselijk geweld sprake van complexe casuïstiek als er na een strafbaar feit sprake is van samenloop van strafrecht en/of bestuursrecht en/of zorg en er problemen zijn op twee of meer leefgebieden en er daarnaast sprake is van één van de onderstaande aanvullende criteria: 1) Het risico op herhaling van huiselijk geweld en/of dreiging geweld is zeer groot en er moet met urgentie een veiligheidsplan worden opgesteld, 2) Er is sprake van een intimite terrorist [d.w.z. een dader van huiselijk geweld waarbij de dader het slachtoffer probeert te domineren door controle en macht uit te oefen, psychisch geweld en dreigen met lichamelijk geweld], 3) Minderjarige kinderen zijn (direct) betrokken als dader, slachtoffer of getuige, 4) Dader of slachtoffer kampen met specifieke persoonsgerichte problemen zoals verslaving, LVB, psychiatrie 5) Er is een huisverbod opgelegd naar aanleiding van een geplande screening vanuit het weegteam bij kindermishandelingszaken, 6) Er is sprake van een potentiële stalkingszaak of van een concrete (ernstige) stalkingszaak, waarbij mogelijk Aware [is een mobiel alarmsysteem] van belang wordt geacht, 7) Er is bij de vraagstelling duidelijk expertise nodig vanuit meerdere ketenpartners', via ZVHRR. 
Figuur Aangepast werkproces van de pilot geïntegreerde aanpak huiselijk geweld (september 2018).

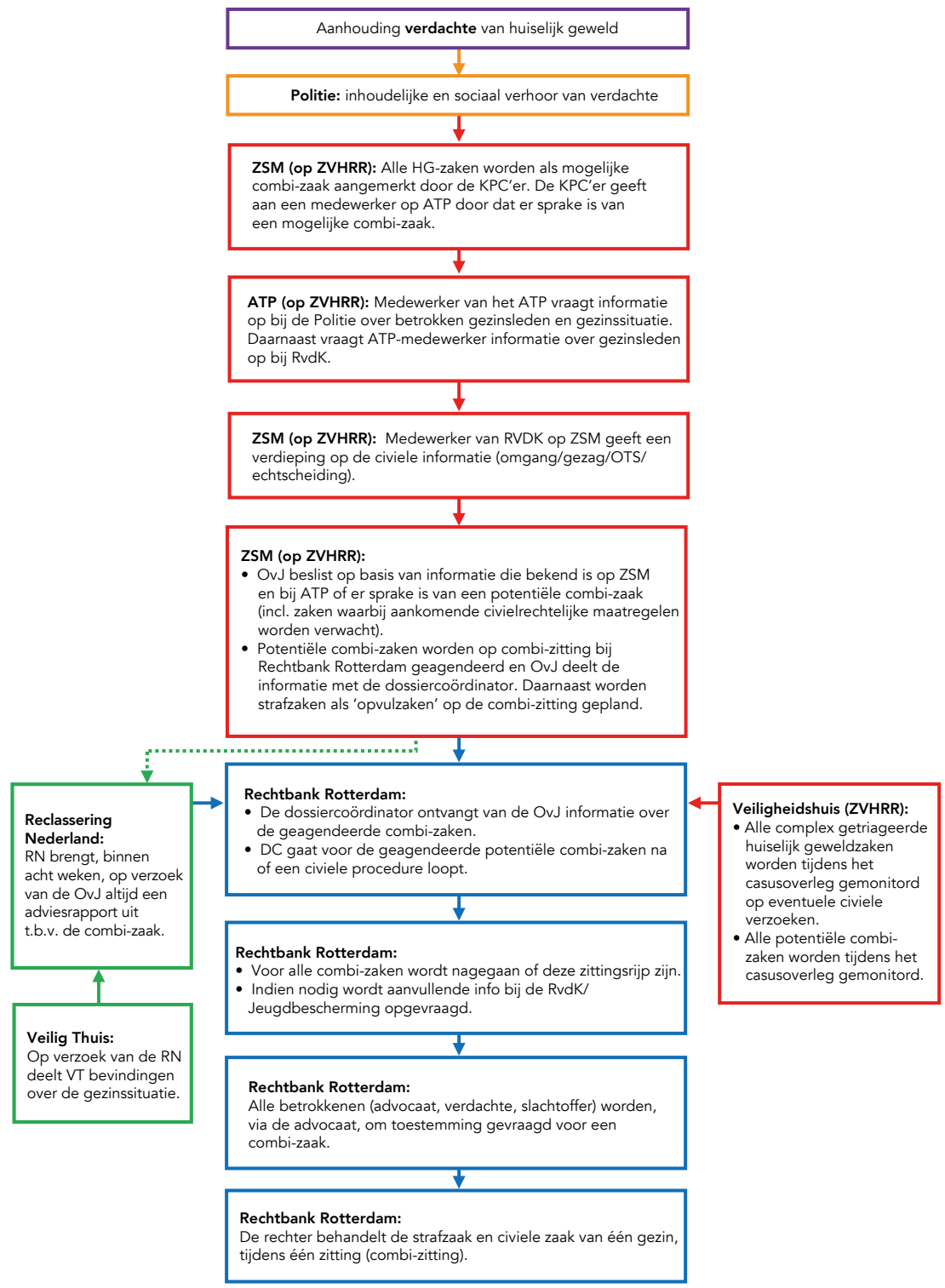




\section{Zorg en Veiligheidshuis Rotterdam (ZVHRR) en Dordrecht (ZVHZH)}

- ZSM: ${ }^{36}$

- Alle huiselijk geweldzaken op ZSM worden door de ketenprocescoördinator (KPC er) op ZSM aangemerkt als mogelijke combi HG. Deze activiteit heeft als doel de officier van justitie erop te attenderen dat uitgezocht moet worden of er daadwerkelijk sprake is van een potentiële combi-zaak.

- De KPCer op ZSM geeft aan een medewerker van het Advies- en Triagepunt (ATP) door dat er in huiselijk geweldzaken mogelijk sprake is van een potentiële combi-zaak. Op het ATP wordt nader informatie verzameld (zie onder ATP).

- Nadat door het ATP en indien van toepassing, informatie is opgevraagd over het gezin bij de Raad voor de Kinderbescherming (RvdK), komt die informatie terecht bij een medewerker van de RvdK op ZSM. Het betreft informatie over (verzoek tot) ondertoezichtstelling van een kind (OTS/VOTS), omgangregelingen en gezag over het kind.

- De medewerker van de RvdK op ZSM geeft aanvullende informatie en schatten de kans op een civiele procedure in.

- De informatie over een (eventuele) civiele procedure deelt de RvdK op ZSM met de officier van justitie op ZSM. De officier van justitie beslist of de procedures die bij een gezin spelen, gecombineerd kunnen worden en op een huiselijk geweldzitting gepland kunnen worden. Als er sprake is van een potentiële combi-zaak dat agendeert de officier de potentiële combi-zaak als zodanig op de huiselijk geweldzitting binnen de rechtbank Rotterdam.

- Naast de combi-zaken die de officier van justitie op de huiselijk geweldzitting binnen de pilot plant, kunnen op de combi-zitting huiselijk geweldzaken gepland worden waar geen civiele zaak verwacht wordt. Te denken valt aan een huiselijk geweldincident bij een samenwonend stel, zonder kinderen. Dit zijn zogeheten 'opvulzaken' die worden ingezet om de beschikbare tijd op de huiselijk geweldzitting binnen de pilot efficiënt in te vullen.

- De verzamelde informatie op ZSM voor de geagendeerde combi-zaken, wordt door de officier van justitie aan de rechtbank Rotterdam gestuurd zodat deze informatie beschikbaar is voor de griffier en de rechter die uiteindelijk de zaken behandelen. ketenpartners samen om - ook buiten kantooruren en in weekenden - zaken als diefstal, vandalisme of bedreiging direct af te handelen. De officier van justitie kan dan na de aanhouding van een verdachte snel een afgewogen besluit nemen over de best passende afdoening, ofwel de straf. Daarbij houdt hij rekening met de wensen en schade van het slachtoffer en de omstandigheden van de dader. De straf is licht waar het kan, zwaar waar het moet en maakt de kans op herhaling zo klein mogelijk. De afdoeningen kunnen binnen en buiten het strafrecht liggen. De officier van justitie beoordeelt of een zaak geschikt is voor een ZSM-aanpak. Bij zwaardere delicten legt de officier van justitie de zaak voor aan de rechter. Via: https://www.politie.nl/themas/ zsm-aanpak-voor-de-afhandeling-van-veelvoorkomende-criminaliteit.html 
- Na de beslissing dat er een zaak als potentiële combi-zaak wordt geagendeerd, vraagt de officier van justitie bij de Reclassering Nederland een adviesrapport ten behoeve van de zitting op de rechtbank.

- ATP

- Nadat melding is gemaakt van huiselijk geweld op ZSM en deze is gemarkeerd als potentiële combi-zaak, wordt de medewerker van het ZVHRR bij het ATP op de hoogte gesteld. Deze medewerker vraagt bij de politie nadere informatie over het gezin en de gezinssituatie op.

- Als blijkt dat er kinderen in het gezin zijn mailt de medewerker bij het ATP aan de Raad voor de Kinderbescherming (RvdK) de personalia van de systeem-/ gezinsleden die bij de huiselijk geweldzaken betrokken zijn met de vraag of er procedures lopen met betrekking tot kinderbeschermingsmaatregelen. Deze informatie wordt door de administratief medewerker van de RvdK teruggestuurd aan de medewerker van het ATP en de medewerker van de RvdK op ZSM.

- Veiligheidshuis

- Sommige huiselijk geweldzaken worden, mits getriageerd als complexe casus, $^{37}$ tijdens het casusoverleg van het Veiligheidshuis besproken. Tijdens het casusoverleg kan blijken dat er huiselijk geweldzaken zijn waar ten tijde van de afdoeningsbeslissing op ZSM geen samenloop van een strafprocedure en civiele procedure was gedetecteerd, toch sprake is van een mogelijke gecombineerde behandeling. De zaken die tijdens het casusoverleg als potentiële combi-zaak worden aangemerkt, worden door de officier van justitie geagendeerd op de combi-zitting op de rechtbank. Voor deze zaken wordt tevens door de officier van justitie een reclasseringsrapport bij de Reclassering Nederland opgevraagd ten behoeve van de rechtszitting.

- Daarnaast komen alle potentiële combi-zaken tijdens het casusoverleg opnieuw aan de orde om te monitoren of er inmiddels een civiele zaak aanhangig is gemaakt.

- Raad voor de Kinderbescherming

- Op verzoek van de medewerker van het ATP, levert een administratief medewerker van de RvdK informatie over systeem-/gezinsleden wat betreft eventuele (verzoeken tot) kinderbeschermingsmaatregelen.

- Nadat potentiële combi-zaken zijn geagendeerd en zijn gemeld aan de

37 'Er is bij huiselijk geweld sprake van complexe casuïstiek als er na een strafbaar feit sprake is van samenloop van strafrecht en/of bestuursrecht en/of zorg en er problemen zijn op twee of meer leefgebieden en er daarnaast sprake is van één van de onderstaande aanvullende criteria: 1) Het risico op herhaling van huiselijk geweld en/of dreiging geweld is zeer groot en er moet met urgentie een veiligheidsplan worden opgesteld, 2) Er is sprake van een intimite terrorist [d.w.z. een dader van huiselijk geweld waarbij de dader het slachtoffer probeert te domineren door controle en macht uit te oefen, psychisch geweld en dreigen met lichamelijk geweld], 3) Minderjarige kinderen zijn (direct) betrokken als dader, slachtoffer of getuige, 4) Dader of slachtoffer kampen met specifieke persoonsgerichte problemen zoals verslaving, LVB, psychiatrie 5) Er is een huisverbod opgelegd naar aanleiding van een geplande screening vanuit het weegteam bij kindermishandelingszaken, 6) Er is sprake van een potentiële stalkingszaak of van een concrete (ernstige) stalkingszaak, waarbij mogelijk Aware [is een mobiel alarmsysteem] van belang wordt geacht, 7) Er is bij de vraagstelling duidelijk expertise nodig vanuit meerdere ketenpartners', via ZVHRR. 
rechtbank Rotterdam, kan het voorkomen dat de dossiercoördinator van de rechtbank de RvdK om aanvullende informatie vraagt over de (verzoeken voor) regelingen omtrent de kinderen uit de betreffende gezinnen.

- Reclassering Nederland

- De reclassering stelt op verzoek van de officier van justitie een rapport op ten behoeve van de zitting op de rechtbank. In dat rapport geeft de reclassering een omschrijving van de persoonlijke situatie van de verdachte, wordt een inschatting gemaakt van de kans op recidive, geeft de reclasseringsmedewerker een professioneel oordeel over de zaak en brengt advies uit over wat nodig is om herhaling van een strafbaar feit te voorkomen. De aanlevertermijn van de adviesrapporten is ten behoeve van de pilot verkort tot acht weken, in plaats van tien weken.

- Reclassering Nederland vraagt aanvullende informatie op over systeem-/ gezinsleden aan Veilig Thuis.

- Veilig Thuis ${ }^{38}$

- Veilig Thuis deelt, op verzoek van Reclassering Nederland, informatie over alle gezinsleden en hun onderlinge relaties en patronen. Deze informatie wordt opgenomen in het adviesrapport van de reclassering en gebruikt ten behoeve van de behandeling van de combi-zaak op de rechtbank.

\section{Rechtbank Rotterdam}

- De dossiercoördinator van de rechtbank ontvangt van de officier van justitie op ZSM een e-mail over de zaken die als combi-zaken geagendeerd zijn. De mail bevat informatie die op ZSM is verzameld over de verdachte en de eventuele systeem-/gezinsleden. Van de opvulzaken die geagendeerd zijn (zie hierover bullet 6 onder 'ZSM'), ontvangt de dossiercoördinator geen informatie.

- Voor de potentiële combi-zaken die op de huiselijk geweldzitting binnen de pilot geagendeerd zijn, wordt door de dossiercoördinator van de rechtbank Rotterdam gecheckt of er een civiel verzoek is ingediend. Dit wordt gedaan om na te gaan of de strafprocedure en civiele procedure eventueel gelijktijdig behandeld kunnen worden in de vorm van een combi-zaak.

- Voor alle combi-zaken wordt door de dossiercoördinator bij de betreffende griffie (jeugd-/familierecht) nagegaan of de civiele zaak zittingsrijp is. Dit houdt in dat alle revelante onderzoekswensen, zoals een beschermingsonderzoek door de RvdK zijn uitgevoerd. Wanneer dat het geval is en de zaak daadwerkelijk gecombineerd kan worden, wordt het dossier opgevraagd en gescreend op inhoud.

38 Bij Veilig Thuis kunnen meldingen over huiselijk geweld binnenkomen. Veilig Thuis heeft de wettelijke taak om naar aanleiding van een melding van huiselijk geweld onderzoek te doen of er sprake is van huiselijk geweld. In haar onderzoek kijkt Veilig Thuis naar alle leden van het gezin/ huishouden en het sociale netwerk om de onderlinge relaties en patronen inzichtelijk te maken, om zo een beeld van het probleem en de oplossing te krijgen. Veilig Thuis deelt daarbij de informatie met professionals die actief een bijdrage leveren aan het realiseren van veiligheid in het gezin. Zie: https://vng.nl/files/vng/publicatie_bijlagen/2019/20141107_vng_model_handelingsprotocol_veilig_thuis.pdf. 
- De dossiercoördinator vraagt, indien nodig, aanvullende informatie op bij de RvdK en/of Jeugdbescherming.

- Alle betrokkenen (slachtoffer, verdachte en advoca(a)t(en)) worden, via de advocaat, telefonisch om toestemming gevraagd voor de combi-zitting. Als duidelijk of er al dan niet toestemming wordt gegeven, wordt deze uitkomst gedeeld met alle partijen. Indien toestemming wordt gegeven wordt de zaak als combi-zaak behandeld, anders wordt alleen de strafzaak op de huiselijk geweldzitting binnen de pilot behandeld.

- Twee weken voor de zittingsdatum worden de twee aparte dossiers van de civiele zaak en de strafzaak naar de zittingsgriffier gestuurd.

- Voor de behandeling van combi-zaken en huiselijk geweldzaken op de combizitting is meer tijd beschikbaar dan voor de behandeling van een huiselijk geweldzaken op een politierechterzitting. Voor de behandeling van een combizaak wordt ongeveer een uur uitgetrokken, voor een huiselijk geweldzaak (zonder civiele zaak) ongeveer een half uur. Voor de behandeling van een huiselijk geweldzaak op een politierechterzitting ongeveer 20 minuten. 


\section{Begeleidingscommissie}

Prof. Dr. G.M.F. Römkens (Universiteit van Amsterdam)

Mr. J.R.M. van Schoonderwoerd den Bezemer-Wolters (Landelijk Officier van Justitie Zeden, Huiselijk Geweld en Kindermishandeling)

Mr. E.J. Stalenberg (Rechtbank Rotterdam)

Dr. H.G.E. Verberk (Raad voor de rechtspraak)

Ma G. Waltz MA (Verwonderzoek)

Dhr C.N.M. Zeebregts (Zorg- en Veiligheidshuis Rotterdam Rijnmond) 


\section{DSP-groep BV}

Van Diemenstraat 410

1013 CR Amsterdam

+31 (0)206257537

dsp@dsp-groep.nl

KvK 33176766

www.dsp-groep.nl

DSP-groep is een onafhankelijk bureau voor onderzoek, advies en management, gevestigd aan de IJ-oevers in Amsterdam. Sinds de oprichting van het bureau in 1984 werken wij veelvuldig in opdracht van de overheid (ministeries, provincies en gemeenten), maar ook voor maatschappelijke organisaties op landelijk, regionaal of lokaal niveau. Het bureau bestaat uit 40 medewerkers en een groot aantal freelancers.

\section{Dienstverlening}

Onze inzet is vooral gericht op het ondersteunen van opdrachtgevers bij het aanpakken van complexe beleidsvraagstukken binnen de samenleving. We richten ons daarbij met name op de sociale, ruimtelijke of bestuurlijke kanten van zo'n vraagstuk. In dit kader kunnen we bijvoorbeeld een onderzoek doen, een registratie- of monitorsysteem ontwikkelen, een advies uitbrengen, een beleidsvisie voorbereiden, een plan toetsen of (tijdelijk) het management van een project of organisatie voeren.

\section{Expertise}

Onze focus richt zich met name op de sociale, ruimtelijke of bestuurlijke kanten van een vraagstuk. Wij hebben o.a. expertise op het gebied van transitie in het sociaal domein, kwetsbare groepen in de samenleving, openbare orde \& veiligheid, wonen, jeugd, sport \& cultuur.

\section{Meer weten?}

Neem vrijblijvend contact met ons op voor meer informatie of om een afspraak te maken. Bezoek onze website www.dspgroep.nl voor onze projecten, publicaties en opdrachtgevers. 